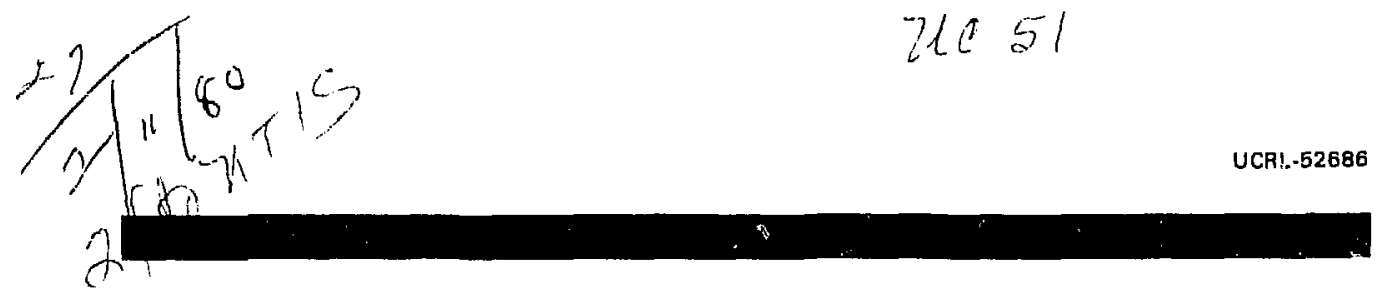

\title{
HYDROGEOCHEMICAL AND STREAM SEDIMENT SPECIAL RECONNAISSANCE REPORT FOR THE DEEP CREEK MOUNTAINS, NEVADA AND UTAH
}

B. Qualheim

April 1979

\section{MASTER}

Work performed under the auspices of the U.S. Department of Energy by the UCLLL under contract numbor W-7405-ENG-48.
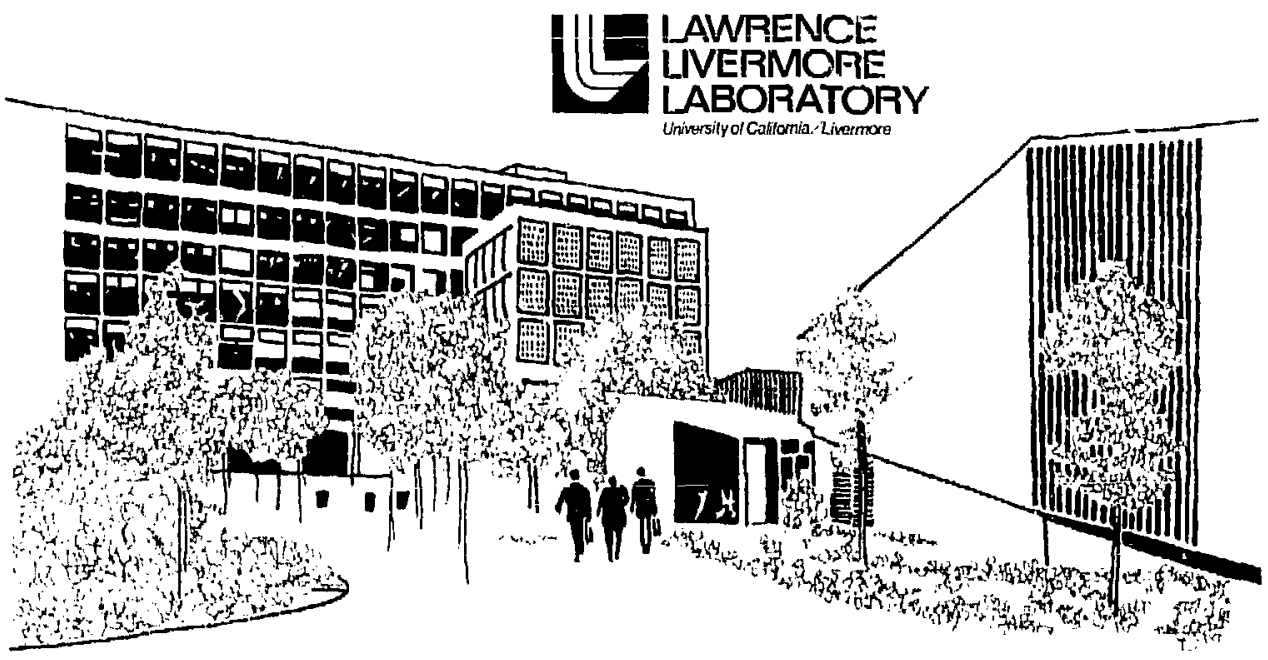


\title{
㢟
}

LAWRENCE LIVERMORE LABORATOHY

University of Cahtornia : Livermore, Callionia 94550

UCRL. 52886

\section{HYDROGEOCHEMICAL AND STREAM SEDIMENT SPECIAL RECONNAISSANCE. REPORT FOR THE DEEP CREEK MOUNTAINS, NEVADA AND UTAH}

\author{
B. Qualheim
}

MS. date: April 1979

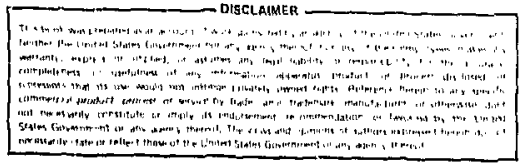




\section{CONTENTS}

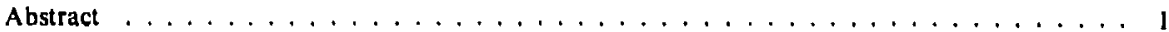

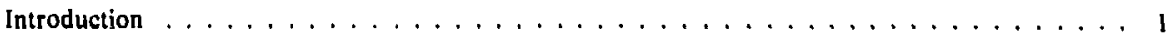

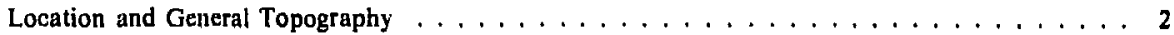

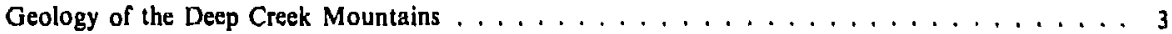

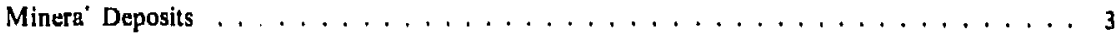

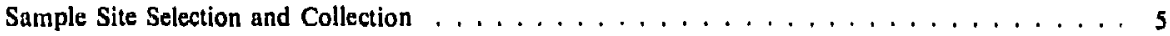

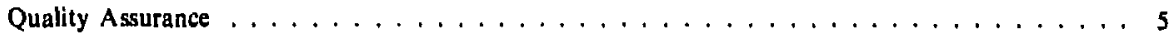

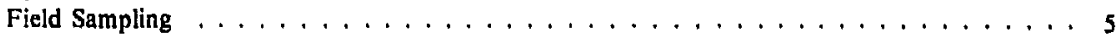

Laboratory Analysis $\ldots \ldots \ldots \ldots \ldots$

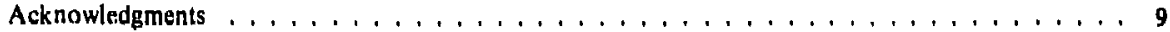

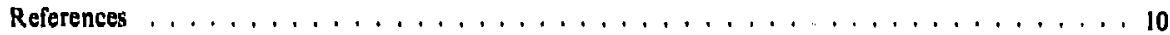

Bibliography $\ldots \ldots \ldots \ldots \ldots \ldots$

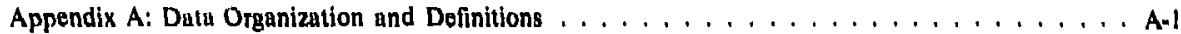

Appendix B: Numerical Results of Reconnalssance Survey $\ldots \ldots \ldots \ldots$. . . . . . . . . . B-1

\section{FIGURES}

Figure 1. Location mup of the Deep Creek aren . . . . . . . . . . . . . . . . . 2

Figure 2, Generulized geologic map of the Deep Creek Mountuins , . . . . . . . . . . . 4

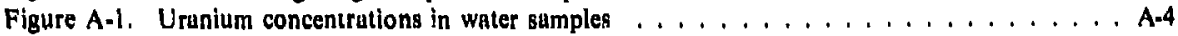

Figure $\mathbf{A - 2}$. Uranium concentrations in sediment samples $\ldots \ldots \ldots \ldots \ldots$

Figure A-3. Histogram (a) and cumulative frequency distribution (b) of uranium concentration for water samples plotted in Overlay 1 B $\ldots \ldots \ldots$

Figure A-4. Histogram (a) and cumulative frequency distribution (b) of field conductivities for water samples plotted in Overlay $1 \mathrm{C} \ldots \ldots \ldots \ldots$

Figure A-5. Histogram (a) and cumulative frequency distribution (b) of uranium concentration for sediment samples plotted on Overlay $2 \mathrm{~B} \ldots \ldots \ldots$

Figure A-6. Histogram (a) and cumulative frequency distribution (b) of thorium concentrations for sediment samples plotted on Overlay $2 \mathrm{C} \ldots \ldots \ldots$

\section{TABLES}

Table 1. Instrumental neutron activation analysis sediment quality of data summary . . . . . . 7

Table 2. Optical emission spectrometry (ICP) water quality assurance data summary . . . . . . . 8

Table 3. Delayed neutron assay for uranium analyses of DOE interlaboratory comparison samples ......................... 8

Table B-1. Sediment unalysis; dry and strean sites $\ldots \ldots \ldots \ldots \ldots \ldots$

Table B-2. Water analysis; streams . . . . . . . . . . . . . . . . . . . . B-7

Table B-3. Water analysis; spring and well sites $\ldots \ldots \ldots \ldots \ldots \ldots$ 


\section{HYDROGEOCHEMICAL AND STREAM SEDIMENT SPECIAL RECONNAISSANCE REPORT FOR THE DEEP CREEK MOUNTAINS, NEVADA AND UTAH.}

\section{ABSTRACT}

This report represents the results of the reconnaissance sampling of the Deep Creek Mountains of western Utah. The Deep Creek range is located in the northwest corner of the Delta NTMS 1:250,000 and the southwestern corner of the Tooele NTMS $1: 250,000$ sheets and covers an area of $1750 \mathrm{~km}^{2}$. Samples collected in this study include dry and wet stream sediments and water from available streams, wells, and springs. The samples were analyzed for uranium, as well as 15 to 20 trace element, using neutron activation techniques. In addition, field and laboratory measurements were made on the water samples. Analytical data and field measurements are presented in tabular hard copy and fiche format. Watersample site locations, water-sample uranium concentrations, sediment-sample site locations, and sediment-sample uranium concentrations are shown on separate overlays.

\section{INTRODUCTION}

The National Uranium Resource Evaluation (NURE) Program was cstablished to evaluate domestic uranium resources in the cuntinentul U.S. and identify areas favorable for uranium exploration.

As part of this eff - - Lawrence Livermore Laboratory (LLL) acquired a proper set of field samples in the designated field areas, processed and analyzed the materials, and compiled the data in a report. The resulting hydrogeochemical and stream sediment reconnaissance (HSSR) reports are made available to the public by the Grand Junction Office of the Depariment of Energy through simuitaneous release at several locations. Before starting a major field reconnaissunce coverage, LLL conducted one or more orientation studies in the geological province, providing a rational sediment- and water-sampling program sensitive to variable geological and climatic conditions that exist in the ares. ${ }^{1,2}$ In this way, the sediment and water samples reflect as nearly as possible the metallogenic nature of the regisn with particular emphasis on uranium mineralization. A description of sample collection and processing metinds is available.

The samples were analyzed for uranium by delayed neutron counting (DNC). Instrumental neutron activation analysis (INAA) was used to measure the trace- and major-element content of sediment samples as well as the uranium concentrations of some samples. An automated transport and detection system described by Smith $^{3}$ performed the INAA and DNC. The GAMANAL code described by Gunnink and Niday was used to interpret the gamma spectra during data reduction of INAA results. The NURAB code described by Heft and Martin $^{5}$ and McMillan and Carver ${ }^{6}$ produces the elemental concentration values.

An automated optical emission spectrometer equipped with an argon plasma source provided traceand major-element analyses of water samples. A. modified spectrophotometric anulyzer was used to measure chloride and sulphate concentrations in water saltiples. 


\section{LOCATION AND GENERAL TOPOGRAPHY}

The Deep Creek Range (Fig. 1) is located in the Basin and Range physiographic province along the Nevada-Utah border about $64 \mathrm{~km}$ south of Wendover, Utah, covering approximately $1750 \mathrm{~km}^{2}$, It is an elongate mountain range bordered on the east by the alluvial Snake Valley and the Great Salt Lake Desert and on the west by the Ibapah Valley. Elevations range from $2500 \mathrm{~m}$ in the north to $3900 \mathrm{~m}$ in the south. The Snake and Ibapah Valleys are the main discharge basins for the Deep Creek Range. These two main drainage systems then flow north into the Great Salt Lake Desert.

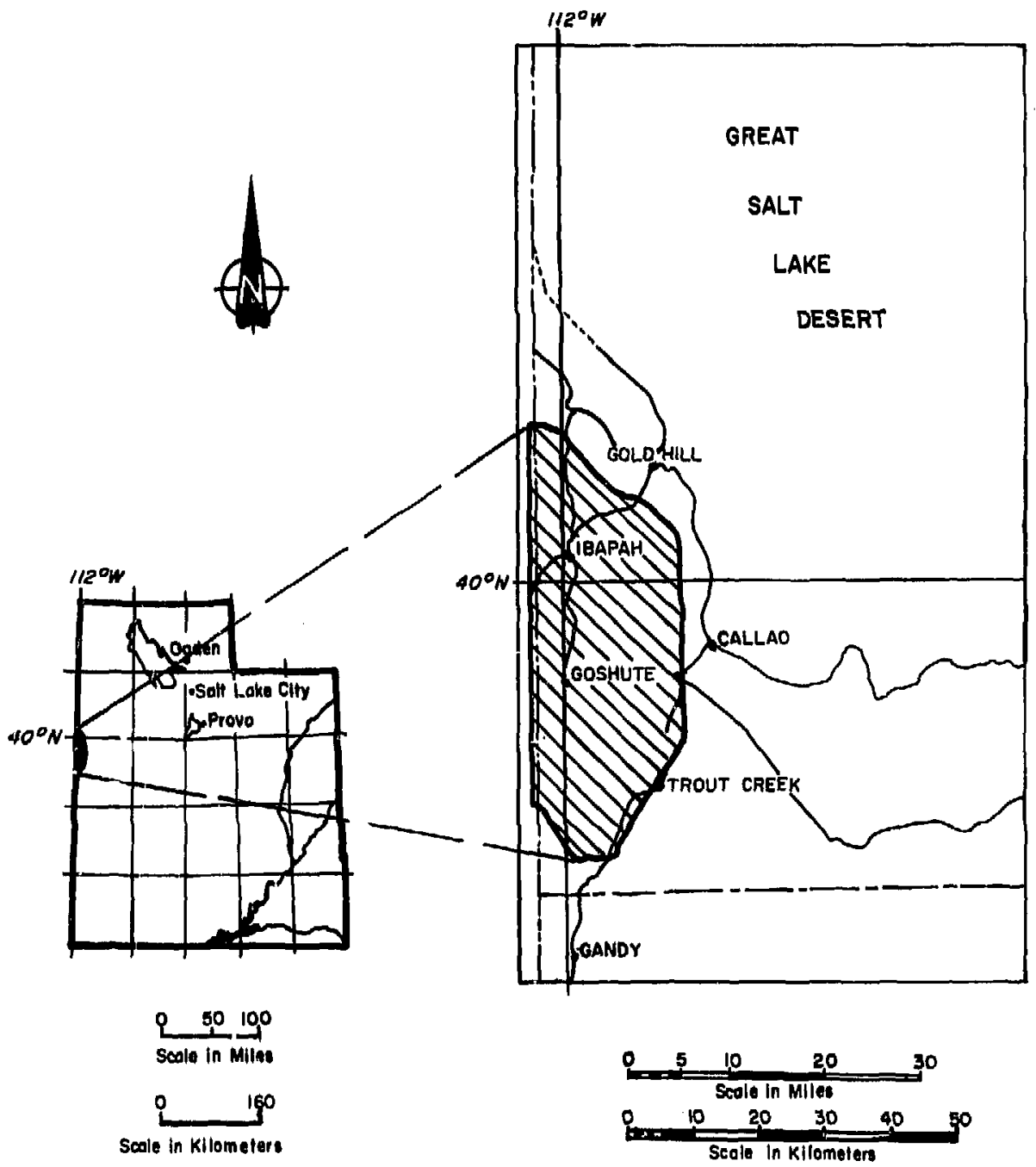

FIG. 1. Location map of the Deep Creek area. 


\section{GEOLOGY OF THE DEEP CREEK MOUNTAINS}

The Deep Creek Range is a horst, bounded by northwest-trending normal faults. The rocks range in age from Precambrian to Permian and consist of sedimentary and metasedimentary rocks; they are intruded by the Tertiary Gold Hill quartz monzonite stock at the north end and the Early Tertiary Ibapah granite stock in the south central section (Fig 2). Tertiary and Quaternary extrusive rocks occur in the north and central parts of the range.

The Precumbrian rocks can be divided into three distinct units: the Trout Creek Sequence, the Johnson Pass Sequence, and the Water Canyon Sequence. The Trout Creek Sequence consists of $2900 \mathrm{~m}$ of metasedimentury rocks ranging from schist to quartzite. The Johnson Pass Sequence is $3300 \mathrm{~m}$ thick and consists of schist, quartaite, and minor beds of quartzose marble and amphibolite. The Water Canyon Sequence is $1600 \mathrm{~m}$ of urgillite, quurtzite, and shule,

The Paleozoic section srops out on the west side of the range and is made up of limestone and dolomite with minor quurtzite and shale.

The Gold Hill stock (Fig, 2) is located in the northern part of the range and crops out over approximately $64 \mathrm{~km}^{2}$. The stock is composed of quartz monzonite and has been assigned a Late Eocene or Early

Oligocene uge. ${ }^{2}$ The Ibapah stock (Fig. 2) in the south central part of the range covers approximately $102 \mathrm{~km}^{2}$. This granitic stock contuins numerous pegmatite, aplite, granite porphyry, and rhyolite dikes. In addition, three smull alaskite intrusions occur in the southern part near Trout Creek.

Tertiary and Quaternary volcanic flows and pyroclastic rocks are found in the northern and southern parts of the range. Additional geologic information can be obtuined from Refs. 7 through 13.

\section{MINERAL DEPOSITS}

Mineral deposits fall into four types: pegmatite dikes, hydrothermal veins, hydrothermal replacement bodies, and contact metasomatic deposits. The mineral deposits are associated with intrusive bodies, particularly the northern Gold Hill quartz monzonite and quartz monzonite porphyry and the southern beryllium-bearing pegmatite dikes in the Ibapah stock. Mining in the Deep Creek Mountains produced significunt quantities of gold, silver, lead, copper, zinc, arsenic, 'ungsten, and mercury. Mining activities began in the late 1800's and continued sporadically until the 1950's.

The only record of uranium mineralization is a 1977 investigation by the U.S. Bureau of Mines. ${ }^{14,15}$ This investigation indicates shallow uranium deposits along alluvial fans downslope from the granitic intrusives,

The Bureau of Land Management has recently (1977) tentatively withdrawn the Deep Creek Mountains as an emergency primitive area, although legislation on this tentative withdrawal is still pending. ${ }^{14}$ There is, however, considerable industrial interest in uranium exploration in the area. This report includes 78 sites that were previously sampled by Atlas Minerals Inc. These sites are located in the southern part of the range and are found in Appendix B (Nos. 15601-15679). 


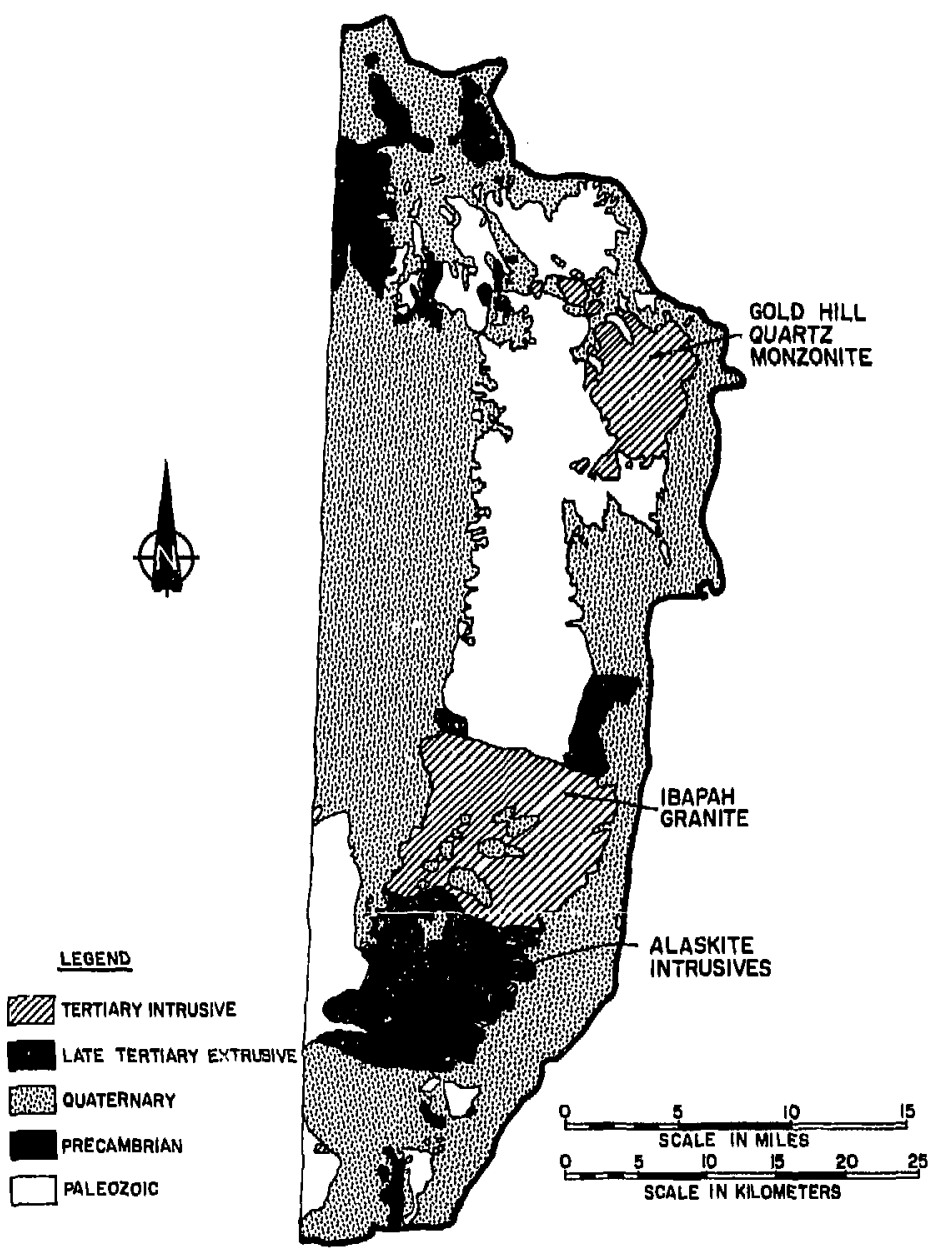

FIG, 2. Generalized geologic map of the Deep Creek Mountains. 


\section{SAMPLE SITE SELECTION AND COLLECTION}

The selection of representative sample sites is the most important aspect of sample acquisition. In the site-selection process:

- Sites were chosen to measure the mobility of uranium in various geological environments.

- Sites were selected to minimize environmental contamination from agriculture, mining, etc.

- Sites were selected along range fronts to ensure minimum windblown contamination.

- Samples along the fan aprons and in lowlands were biased toward ground water with minimal surface sampling because of windblown contamination.

- Samples in small drainages were taken along the range fronts at the apex of alluvial fans.

- Sites in larger drainages were placed up the canyons along tributaries to obtain representative coverage.

- Sediments were sieved to eliminate fines that may have resulted from windblown contamination. Sediments sampled and reported are the fraction between 500 to $1000 \mu \mathrm{m}$.

We obtained un average gediment-site density of one site per $10 \mathrm{~km}^{2}$.

'To minimize the temporal factor, available water was sampled over a short period during the summer of 1977. Because the region was at near-drought conditions, the uranium concentrations are probably at the maximum values. For this reason, sampling during a wetter year might result in uranium values lower than those collected in 1977.

Sites were selected by LLL geologists and sampling was done by contract geologists. Groltnd-water site selection and sampling was tonducted by the University of Nevada-Desert Research Institute.

\section{QUALITY ASSURANCE}

\section{FIELD SAMPLING}

Lawrence Livermore Laboratory observers occasionally accompanied the contract sampling crews; LLL geologists resampled approximately $5 \%$ of the project sites. More than $95 \%$ of the resampled sites were uccurately located on available maps or photos. The remaining sites were plotted within $200 \mathrm{~m}$ of the correct location.

Samples from the site revisits are reported in the tables by quality control cross-reference numbers and the alternate site numbers are tabulated. Analytical replicates were also run on about $10 \%$ of all samples. Comparison of the sediment replicate results with the original samples shows a $10 \%$ standard deviation in measurement values. This $10 \%$ is the natural variability of the sampling and analysis.

\section{LABORATORY ANALYSIS}

Instrumental neutron activation anulysis (INAA) and delayed neutron counting (DNC) are per* formed using the automated transpoit and detection system installed at the Livermore Pool Type Reactor. Water samples are analyzed by optical eınission spectrometry using an inductively coupled argon plasma (ICP) source.

We used the GAMANAL code ${ }^{4}$ to interpret the gamma spectra during data reduction of INAA results, while the NURDAC ${ }^{5,6}$ code produced elemental concentration values, Not all elements can be identified in every sample. Our experience suggests that, in general, the detection limits for elements reported here are those given in column 2 of Table 1 .

The error associated with a DNC uranium measurement is typically $1 \%$ of the reported value for sediments and $2 \%$ for water analyses. 
The emission spectrometer data is automatically referenced to a known laboratory standard analyzed between each group of six samples. System calibration against a second known standard solution precedes each batch of 72 samples. Water data from the region were taken from "lab acidified" samples. Unacidified, filtered $(0.45-\mu \mathrm{m})$ water samples were collected and returned to $L L L$, placed in storage for severa! months, acidified to approximately $\mathrm{pH} \mathrm{l}$, and allowed to stand for two weeks prior to unalysis. This procedure was applied after it was noted that in several of the plastic-bag-lined bottles, the plastic bags had broken. It is uncertain if tab acidification completely reversed precipitation of certain components or exchange reactions with the polyethylene container. Therefore, the user should be aware that some analyses may not be representative of the aclual water composition.

Six types of samples are routinely run for calibration of the various analytical systems and as a quality-assurance measure:

- Elemental standards to establish emission spectrometry and spectrophotometry ealibration and to determine physical parameters for the uctivation analysis system.

- Blanks that are processed along with samples and analyzed to detect any source of contaminathon. No significant amount of uny element reported here has been detected.

- Splits of samples to determine whether the results of all analytical systems are reproducible. These data are included in the microfiche data tables. Reproducibility is generally found to be within the eslimated standard deviations of the measurements.

- Qualityncontrol samples, which are run by all systems at an approximate ratio of 1:30 to check precision of the measurements and to detect long-term drift. Results are summarized in Tuble 1, colunin 3. The accuracy of the measurements is generally comparable to the errors estimated from the analytical uncertainties.

- Standard reference materials to determine the accuracy of the measurements in actual simples. Results are tabulated in Table 2. In general, the bias is comparable to the precision of the metsurement.

- Interlaboratory comparison samples for uranium are distributed under the auspices of DOE to the various laboratories participating in the NURE program. Analyses of these samples are collected and reported monthly by the Ames Laboratory. ${ }^{16}$ This data is summarized in Table 3.

While care has been taken to provide rcliable sampling and analyses, verificution of individual unalyses is beyond the scope of this report. The data should be viewed statistically because "one-point anomalies" muy be misleading. Regional trends, however, should be reliable. 
TABLE 1. Instrumental neutron activation analysis sediment quality assurance data summary.

\begin{tabular}{|c|c|c|c|}
\hline Element & $\begin{array}{c}\text { Detection } \\
\text { Umit, }{ }^{\mathrm{p}} \text { ppm }\end{array}$ & $\begin{array}{c}\text { Precision } \\
x_{6}^{6} \\
\end{array}$ & $\begin{array}{l}\text { Accuracy } \\
\% \text { blas }\end{array}$ \\
\hline $\mathrm{Ag}$ & 500 & $\mathrm{ND}^{d}$ & ND \\
\hline $\mathbf{A} \mathbf{I}$ & 50 & 10 & -7 \\
\hline As & 3 & 6 & -1 \\
\hline $\mathrm{Ba}$ & 100 & 13 & ND \\
\hline $\mathrm{Br}$ & 5 & ND & $\mathrm{NR}^{\mathrm{B}}$ \\
\hline $\mathrm{Ca}$ & 20,000 & 7 & ND \\
\hline$C_{0}$ & 15 & ND & NR \\
\hline $\mathrm{Cl}$ & 50 & ND & NR \\
\hline Co & 3 & 5 & +6 \\
\hline Cr & 30 & 8 & +13 \\
\hline $\mathrm{Ca}$ & 30 & 5 & NR \\
\hline Dy & 0.2 & 10 & NR \\
\hline Eu & 0.1 & 16 & NR \\
\hline $\mathrm{Fe}$ & 2,000 & 5 & $\mathbf{s}$ \\
\hline $\mathrm{HI}$ & 1 & 14 & NR \\
\hline $\mathrm{Hg}$ & 500 & ND & NR \\
\hline $\mathrm{K}$ & 2,000 & 7 & ND \\
\hline Lo & 0.3 & 4 & NR \\
\hline Lu & 2 & 22 & NR \\
\hline Mg & 50 & 10 & +4 \\
\hline$M n$ & 0.2 & 4 & +11 \\
\hline $\mathrm{Na}$ & 20 & 4 & 0 \\
\hline $\mathbf{R b}$ & 150 & 4 & ND \\
\hline$s b$ & 0.5 & 4 & -5 \\
\hline Sc & 0.1 & 5 & -5 \\
\hline Sm & 0.3 & 4 & NR \\
\hline $\mathbf{S r}$ & 40 & ND & ND \\
\hline $\mathbf{T a}$ & 3 & 20 & NR \\
\hline Tb & 20 & ND & NR \\
\hline Th & 2 & 4 & -6 \\
\hline $\mathbf{T I}$ & 200 & 8 & +2 \\
\hline $\mathbf{U}$ & 2 & 12 & -4 \\
\hline $\mathbf{v}$ & 1 & 5 & +4 \\
\hline$w$ & 30 & ND & NR \\
\hline $\mathbf{Y b}$ & 3 & 13 & -6 \\
\hline $\mathbf{Z n}$ & 200 & 16 & ND \\
\hline
\end{tabular}

approximate lower limits for detectlon in "typical" sediment samples.

bprecision is an estimate of the reproduciblity of anvyses, Valuos ontered are percent standard devintion of a masure. ment for 30 analyses of control sumples over a flve month period. (8co footnate c, Table 3.)

"Accuracy is a measure of analytical agreoment with "known" values. Entrics are the porcent deviation from unity of the ratio ,.i measured to known valuet, averaged for 15 measurements obtelned uver a flvo-month period, (See footnote $d$, Tabie 3.) Known yalues wero obtainad from the Canadian Association lor Applied Spectroscopy.

$\mathrm{d}_{\mathrm{ND}}=$ not dotected.

ONR a not reported for standards. 
TABLE 2. Optical emission spectrometry (ICP) water quality-assurance data summary.

\begin{tabular}{ccc}
\hline Element & $\begin{array}{c}\text { Detection limit, } \\
\text { ppb }\end{array}$ & $\begin{array}{c}\text { Precision } \\
\text { \% bias }\end{array}$ \\
\hline $\mathrm{Al}$ & 12 & +16 \\
$\mathrm{As}$ & 20 & +34 \\
$\mathrm{Ca}$ & 30 & +10 \\
$\mathrm{Cd}$ & 4 & +2 \\
$\mathrm{Co}$ & 4 & -1 \\
$\mathrm{Cu}$ & 4 & +6 \\
$\mathrm{Fo}$ & 4 & +5 \\
$\mathrm{~K}$ & 70 & +7 \\
$\mathrm{Mg}$ & 5 & +5 \\
$\mathrm{Na}$ & 5 & +5 \\
$\mathrm{Nl}$ & 50 & -13 \\
$\mathrm{~Pb}$ & 40 & -2 \\
$\mathrm{~V}$ & 4 & +2 \\
$\mathrm{Zn}$ & 3 & +20 \\
\hline
\end{tabular}

Approximate lower llmits of dotection in watei sumplos. Values givon aro four timus the standasd deviation of the background in each etsmontal channel.

brection is is messure of analytical agreement with known values. Entries are the percent doviation trom unity of the ratio of masured to known values averaged for 15 messurements. (See loutnote d, Table 3.) Known values were obtained from the Environmental Protection Agency.

TABLE 3. Delayed neutron assay for uranium analyses of DOE interleboratory comparison samples during analytical activity for the Deep Creek Mountains.

\begin{tabular}{|c|c|c|c|c|c|}
\hline & \multicolumn{2}{|c|}{ Water, ppb } & \multicolumn{3}{|c|}{ Sediment ppm } \\
\hline & A2 & $\mathbf{B 2}$ & R1 & si & Tl \\
\hline Number of analyces & 7 & 7 & 9 & 7 & 9 \\
\hline Recommended valuea & 0.98 & 9.98 & 5.33 & 11.2 & 96.2 \\
\hline Mean varuob & 1.12 & 10.4 & 5.32 & 10.7 & 92.9 \\
\hline Standerd devlation ${ }^{\circ}$ of a neesurement, $\%$ & 6.0 & 3.0 & 5.) & 4.0 & 2.0 \\
\hline Bias, $\pm \%$ & +14 & +4 & +0.2 & +4.7 & +3.6 \\
\hline
\end{tabular}

${ }^{\text {a}}$ Rocommended values for amplos A2 and B2 are trom lootope dllution mass apeotrometry (Ref. 16j. Values tor samples

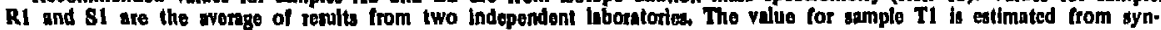
thesis perametora.

bMan of LLL mousrements

$\frac{100}{\bar{x}}\left[\frac{\sum^{n}\left(x_{n}-\bar{x}\right)^{2}}{(n-1)}\right]^{1 / 2}$. 


\section{ACKNOWLEDGMENTS}

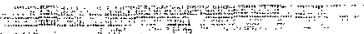

These data are the cumulative result of efforts by many individuals without whose support this report would not have been possible. LLL geologists assisting in this report are D. Leach and T. Steinborn. The author fielded the sampling programi and was assisted by students S. Schultz and M, Knowltori. Processing and analysis of the sediment, rock, and water samples were performed under the direction of C. Smith; processing and inventory control were the responsibitity of W. Hutchin. R. Van Konynenburg performed neutron activation analysis, E. Peck and $A$. Langhorsi conducter emissión spectrometry, and R. Lisn was responsible for special chemisities, G. McMillan develops t and supervitsed data processing, and data base management functions were porformed by $B$, Gumm. Special thanks go to R, Carpenter, L. Manchester, and J. Attebery for the data tables, histograms, overlays, and report coordinatisi. Ground-water site selection, sample qequisition, and fiuld measurements were provided by the Desert Research Instilute. Sincere apprecidtion is also expressed to the land owners, the U.S Forest Service, and Bureau of Land Management personnel who granted access to the lands under their control so that the survey could be completed. The author also thanks $P$. Neison of Allas Minerals Inc. For generously supplying us with sample splits, which added significantly to the sample density. The author also gratefully ucknowledges P. Proctor for her excellent draining work. 


\section{REFERENCES}

1. K. P. Puchlik, Roach Lake Basin Orientation Study, Nevada, Lawrence Livermore Laboratory, Livermore, Calif,, Hydrogeochemical Reconnaissance Report, 1-P (1977), GJBX-48 (78).

2. K. P. Puchlik, "Collection of Wet and Dry Stream Sediment Sampling," from the Symposium on Hydrogeochemical and Dry Stream Sediment Sampling (Bendix Field Engineering, Grand Junction, Colorado); Lawrence Livermore Laboratory, Livermore, Calif., Prept int UCRL-79246 (1977), GJBX-77 (77).

3. C. F. Smith, Instrumental Neutron Activation Analysis for the NURE Hydrogeochemical Survey, Lawrence Livermore Laboratory, Livermore, Calif., UCRL-79709 (1978)(to be published in 1979),

4. R. Gunnink and J. B. Niday, Computerized Quantitative A ralysis by Gamma Ray Spectroscopy, Description of the GAMANAL Program, Lawrence Livermore Laviratory, Livermore, CaliC, UCRL-51061 Vol. 1 (1972).

5. R, E. Hclt and W. H, Martin, NADAS and MERGE-Computer Codes for Processing Newtron Activation Analysis Data, Lawrence Livermore Luboratory, Livermore, Call., UCRL-52249 (1978)(to be published in 1979).

6. G. G. McMillan and R, D. Caryer, NURAB: A System for Processing Neutron A clivation Analysis Data, Lawrence Livermore Laboratory, Livermore, Calif., UCRL-80259 (1978) (to be published in 1979).

7. K. C. Thomson, Minteral Deposits of the Deep Creck Mountains, Tooele and Juab Counties, Utah, Utah Geological and Mineralogical Survey, Salt Lake City, Utah, Bulletin 99 (June 1973).

8. T. B. Nolen, The Gold Hill Mining Distrlct, Utah, U,S. Gcological Survey, Reston, Va, Professional Paper 177 (1935).

9. T. B. Nolen, Geology of the Deep Creek Moumtain, Tooele and Juab Coumtes, Utah, Utuh Geological and Mineralogical Survey, Silt Lake City, Utuh, Bulletin 77 (1966).

10. B. S. Butler, Ore Deposits of Uiah, U.S. Geological Survey, Reston, Va., Professional Paper 111 (1920).

11. A. E. Custer, "Deep Creek, Clifton Mining District, Utah," Eng. Min. Jour. 103 (1917).

12. K. S. Hilport and R. J. Roberts, Economic Geology, Mineral and Water Resources of Uiah, Utah Geological and Mineralogical Survey, Salt Lake City, Utah, Bulletin 73 (1964),

13. H. M. Shatoury and J. A. Whelan, Mineralization and Alteration Studies in the Gold Hill Mining District, Tooele County, Utah, Utah Geological and Mineralogical Survey, Salt Luke City, Utah, Bulletin 83 (1967).

14. "Industry Newswatch, U.S, and International Mineral News Briefs," Min. Eng. 18 (Nov, 1977).

15. U.S. Department of the Intcrior, Minerals and Materials: A Monthly Study, Washington, D.C. (Sept. 1977).

16. A. P. D'Silva, M. A. Floyd, and W. J. Haas, Jr., Multilaboratory Analytical Quality Control for Hydrogeochemical and Stream Sediment Reconnaissance, published monthly by Ames Luborutory, lowa State University, Ames, lowa. Availuble through NTIS.

\section{BIBLIOGRAPHY}

Anonymous, 1889, "Deep Creek, Clifton mining district, Utah," Eng. Min. Jour, 103, p. 91.6. Anonymous, 1917, Gold Hill-Deep Creek region: Gold Hill Standard 1, 54 (Dec. 28).

Armstrong, R, L., 1963, Geochronology and geology of the eastern Great Bas: ${ }^{2}$, Ph.D. thesis, Yale University. Bick, K. F., 1958, Geology of the Deep Creek quadrangle, western Utah, Ph.D. thesis, Yale University. Burritt, A. G., 1936, Report on the Falkenburg mine, Granite Creek, Juab County, Utah, unpublished report for S. F. Falkenburg, 5 p.

Calkins, F, C, and B, S. Butler, 1943, Geology and ore deposits of the Cottonwood-American Fork area, Uiah, U.S. Geological Survey, Reston, Va., Professional Paper 201, 152 p.

Crawford, A. L, and C. O'Farrell, 1932, "Unusual microscopic features of a newly discovered mercury ore from the Deep Creek Mountains of western Utah," Utah Acad. Sci. Proc. 9, p. 55-59. 
Creasey, S. C., 1966, Hydrothermal alteration, in Geology of the porphyry copper deposits, southwestern North America, S. R. Titley and C. L. Hicks, Eds. (University of Arizona Press, Tucson, Ariz.).

Dunham, W. C., 1959, Geology report on the White Cloud mine area, Deep Creek Mountains near Partoun, Juab County, Uiah, Unpublished report for George and Lawrence Rawlings, 7 p.

Emmons, W.H., 1917, The enrichment of ore deposits, U.S. Geological Survey, Reston, Va., Bulletin 625, $530 \mathrm{p}$.

Everitt, F. W., 1961, Tungsten deposits in Utah, U.S. Bureau of Mines, Department of the Interior, Washington, D.C., Information Circular 8014, $44 \mathrm{p}$.

Flint, A. E., 1962, A report of the results of geologic mapping and exploratory drilling on the Trout Creek beryllium Iungsten property. Juab County, Unpublished report for Western Beryllium Co., 7 p.

Gilbert, G. K., 1875, U.S. Geological and Geographical Survey Terrain, West looth Meridian Report 3, p. 21 187.

Gilhert, G. K., 1890, Lake Bomnevllle, U.S. Geological Survey, Reston, Va., Monograph 1, 483 p.

Gunnell, G, H, and W. A. Young, 1946 Ore del Rey mine, Calao, Utah, Unpublished report, U.S. Bureau of Mines, Department of Interior, Washington, D.C.

Henry, G. A., 1900, "The great Peep Creek county," Salt Lake Mining Review 2 (5), p, 1, 8-9.

Hewitt, W. P., 1958, "Western Utah, eastern ard central Nevada-Utah and eastern Nevada," in Ore deposits of the United States, 1933-1967, J. D. Ridge, Ed., American Institute of Mining Engineers, Salt Lake City, Utah, Sales-Graton Vulume.

Heylmun, E. B., 1965, Reconnalssance of the Tertiary sedimentary rocks in western Utat, Utah Geological and Mineralogical Survey, Salt Lake City, Utah, Bulletin 75, 38 p.

Higgins, W. C, 1917, "Flourishing conditions of Clifton mining district," Salt Lake Mining Review 19 (7), p. 21-26.

Hilpert, L. S., 1964, "Mercury," in Mineral and water resources of Utah, Utuh Geological und Mineralogical Survey, Salt Lake Clty, Utuh, Bulletin 73, p. 108-111.

Johannson, Albert, 1932, A descriptive petrography of the igneous rocks, v. II. The quartz-bearing rocks (University of Chicago Press, Chicago).

Kerr, P. G., 1946, "Tungsten mineralization in the United States," Geol. Soc. Am. Mem. 15, 241 p.

Lindgren, W., 1936, Succession of minerals and temperatures of formation in ore deposits of magmatic affiliations, American Institute of Mining Engineers, Salt Lake City, Utah, Technical Publicution 713.

Macfarren, H. W., 1909, "A trip into Deep Creek country," Salt Lake Mining Revlew 11 (11), p. 17-19.

Morris, H. T. and T. S. Lovering, 1961, Stratigraphy of the East Tintic Mountains, U.S. Gcological Survey, Reston, Va, Professional Paper 361.

Nelson, R. B., 1966, "Structural development of northernmost Snake Range, Kern Mountains and Deep Creek Range, Nevada and Utah," Am. Assoc. Petrol. Geol. Bull. 50 (5), p. 92!-951.

Purk, G. M., 1968, Some geochemical and geochronalogic studies of the heryllium deposits in westem Utah, M.S. thesis, University of Utah, Salt Lake City, Utah.

Regan, A. B., 1917, "Geology of the Deep Creek region, Utah," Salt Lake Mining Review 19 (6), p. 25-28.

Regan, A. B., 1929, "Geology of the Deep Creek reservation ard its environs," Kansas A cad. Scl. Trans. 32, p. $105-116$.

Roberts, R. V., 1964, "Economic geology," in Mineral and watcr resources of Nevada, Nevada Bureau of Mines and Geology, Reno, Nev., Bulletin 65, 314 p.

Robins, L. R., 1938, Report on the Queen of Sheba mine, Spring Creak mining district, Juab County, Utah. Unpublished report for the Queen of Shebu Mining Co., $12 \mathrm{p}$.

Shawe, D. R., 1966, Arizona-New Mexico and Newada-Utah beryllium belts, U.S. Geological Survey, Reston, Va, Professionul Paper 500C, p. C206*C213.

Spurr, J. E., 1906, Ore deposits of the Silver Creek quadrangle, Nevada, U.S. Geological Survey, Reston, Va., Professional Paper 55, 175 p.

Spurr, J. E., and W. R. Cox, 1909, Report on the property of the Queen of Sheba Mining Co., Juab County, Utah, Unpublished report for the Queen of Sheba Mining Co., $12 \mathrm{p}$. 
Stokes, W. L., 1968, "Relation of fault trends and mineralization, eastern Great Basin, Utah," Econ. Geol. 63 (7), p. $751-759$.

Stringham, B., 1958, "Relationship of ore to porphyry in the Basin and Range Province, U.S.A.," Econ. Geol. $53 .(7), p, 806-822$.

Stringham, B, 1966; "Igneous rock types and host rocks associated with porphyry copper deposits," in Geology of the porphyry copper depixils, southwestern North America, S. R. Titley and C. L. Hicks, Eds. (University of Arizona Press, Tucson, Ariz,);

U.S. Bureau of Mines, 1900-1967, Minerals yearbooks.

Whelan, J. A., comp., 1970, Radioactive and isolopic age dtierminations of Utah rocks, Utah Geological and Mineralogical Survey, Salt Lake City, Utah, Bulletin 81, 75 p. 


\section{APPENDIX A \\ DATA ORGANIZATION AND DEFINITIONS}




\section{DATA PRESENTATION}

\section{ORGANIZATION}

The numerical results of this reconnaissance survey are presented in three hardcopy tables (Appendix B), in microfiche tables (back cover pocket), and on six vellum averlays (back cover pocket). In addition, frequency histograms and cumulative frequency plots of the logarithm of the uranium and thorium concentrations and water conduftivities plotter on the overlays are included in the back of Appendix A.

\section{HARDCOPY TABLES}

Solected results of this investigation are presented in the three tables in Appendix B. Additional data on the trace-element content for each of the samples are reported in the microfiche tables. The titles and data reported in each of the three tables are given below.

\section{Sediment analyals, dry and atream sites given In Table B-1}

LLL. sampie number

DOE sumple number

Sumple date

Sumple source and condition

Sieve fraction size, upper limit

Sieve fraction size, lower limit

Possible contamination

Quality-control cross-reference number

Uranium concentration, ppm

Thorium concentration, ppm

Water analysis, river, stream, and lake sittes given in Table $\mathbf{B - 2}$

LLL sample nurnber

DOE sample number

Sample date

Sample source and condition

Water temperature, ${ }^{\circ} \mathrm{C}$

$\mathrm{pH}$ meter

Specific conductance, $\mu \mathrm{mho} / \mathrm{cm}$

Total alkalinity

Phenolphthalein alkalinity

Possible contamination

Uranium concentration, $\mathrm{ppb}$

Quality-control cross-reference site number 
LLL sample number

DOE sample number

Sample date

Sample source and condition

Water temperature, o $\mathrm{C}^{1 / n+1}$

Well depth-type-casing

pH meter

Specific conductance, $\mu \mathrm{mho} / \mathrm{cm}$

Total alkalinity

Phenolphthalein alkalinity

Possible contaminution

Uranium concentrution, ppb

Quality-control cross-reference site number

\section{MICROFICHE TABLES}

The additional clement data gathered for each sample are presented in tables on microfiche film. These tables contain data from neutron activation analyses, special chemistry, and emission spectra analyses. The lable titles are exactly as in the hardcopy tables, and the columnar entries of the hardcopy tables are repented as the first part of each microfiche table. This is followed by the element values arranged in ulphabeticul order uccording to the element's proper name. Because of the amount of data, the tables are subdivided into several parts presented on separate pages.

\section{OVERLAYS}

Full-size vellum overlays for use with National Topographic Map Series (NTMS) $1: 250,000$ scale $1^{\circ}$ $\times 2^{\circ}$ quadrangle are located in the reur pocket of this report. These may be used with the commercially available NTMS map for visual display of the sampling site locations and uranium concentration relative to local geographic features. The NTMS map name and number are given on the overlay. To limil the number of overlays that must be generated for each map, the information presented has been divided into two major classes-wuters and sediments. The site number uranium concentration and thorium concentration of each sample are plotted on separate sheets for each class. Different sample site types (stream vs spring or well water, or wet vs dry sediment) are distinguished by using different symbols in association with the site number. The site type symbol is plotted over the geographic location with the site number plotted beside it. The corresponding concentration range value is indicated in a separate overlay by a symbol whose shape and size varies with the range value. The symbol set employed here is a slightly modified version of that employed by the Geological Survey of Canada in their hydrogeochemical surveys. Two sets of ranges are employed because the average uranium trace-element concentration is nearly a factor of $10^{3}$ larger in sediments than in natural waters, The range assignments are shown in Figs, A-1 and A-2.

The overlays contained in the rear pocket of this report are:

Overlay IA. Site Locations, Water Samples

Overlay IB. Total Uranium Concentrations, Water Samples

Overlay IC. Field Conductivity, Water Samples

Overlay 2A. Site Locations,-Sediment Samples

Overlay 2B. Total Uranium Concentrations, Sediment Samples

Overlay 2C, Total Thorium Concentrations, Sediment Samples 
Water Samples

Uranium (total) consentrations

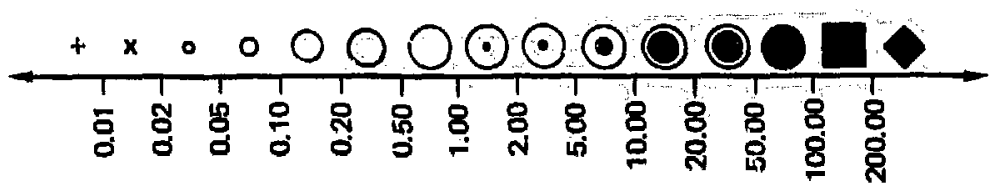

Parts per billion (ppb) by weight

+ Less than 0,01 ppb

(or not detected)

Greater than $200 \mathrm{ppb}$

FIG. A-I. Uranlum cuncentrations In water samples.

Sediment Samples

Uranium and Thorium (total) concentrations

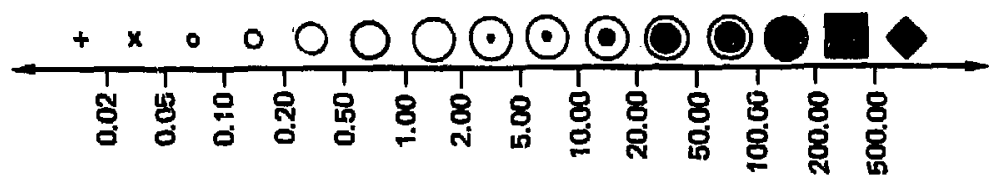

Parts per million (ppm) by waight

+ Less than $0.12 \mathrm{ppm}$

(or not detected)

Greater than 500 ppm

FIG. A-2. Uranium concentrattons in nediment samples. 


\section{HISTOGRAMS AND CUMULATIVE FREQUENCY PLOTS}

Histograms and cumulative frequency plots of the uranium values shown in Overlays $1 \mathrm{~B}$ and $2 \mathrm{~B}$ are given in Fig. A-3 (water samples) and Fig. A-4 (sediment samples). The histogram and cumulative frequency

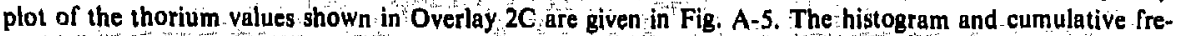
quency plot of the water sample conductivity values shown in Overlay $1 \mathrm{C}$ are presented in Fig. A-6. These are presented as the logarithm of the element concentrations. 

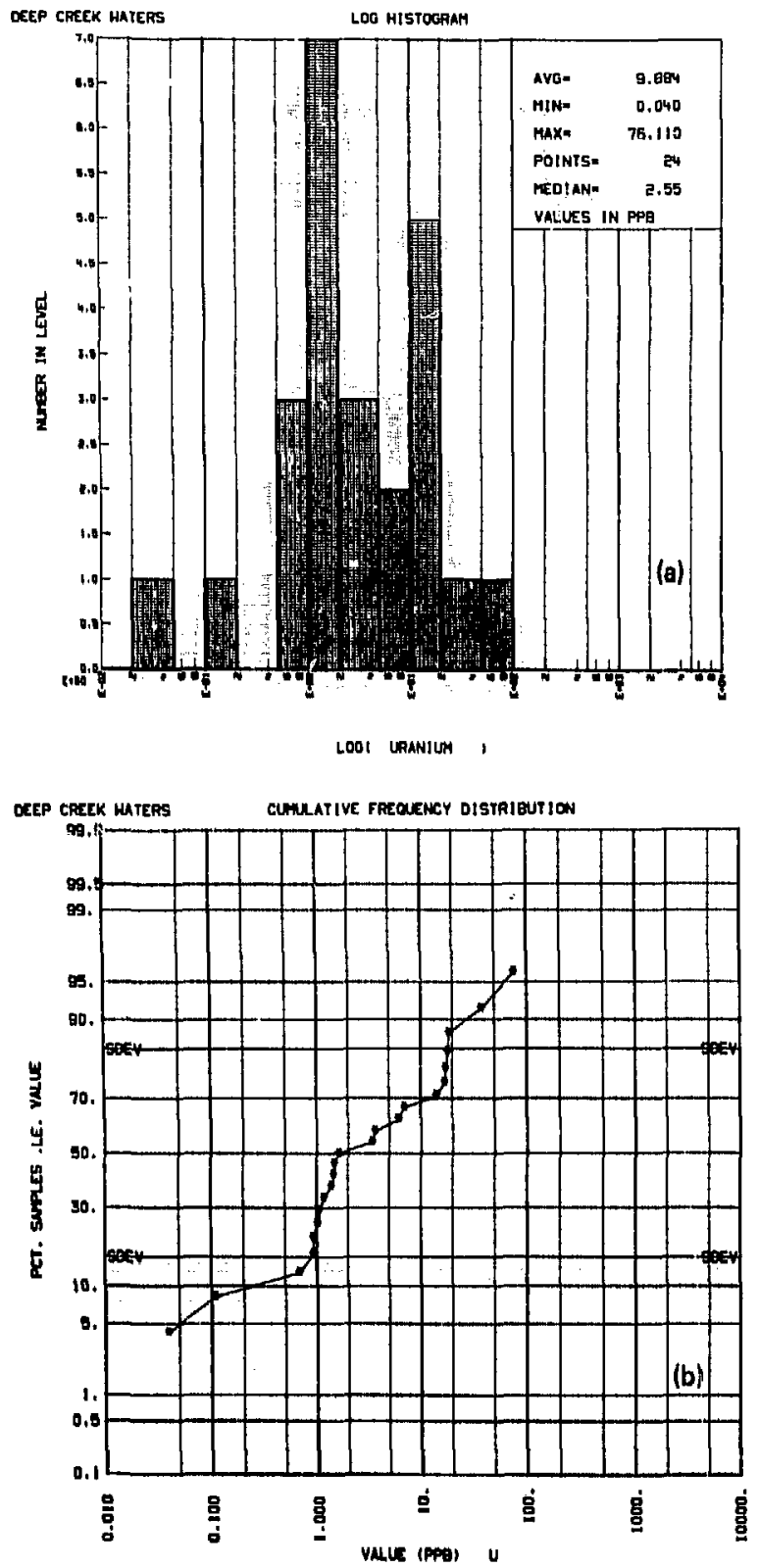

FIG. A-3. Hiatogram (a) and cemulatlve frequency dlstrlbution (b) of uranilum concentration for water samples plotted in Overlay 18. 

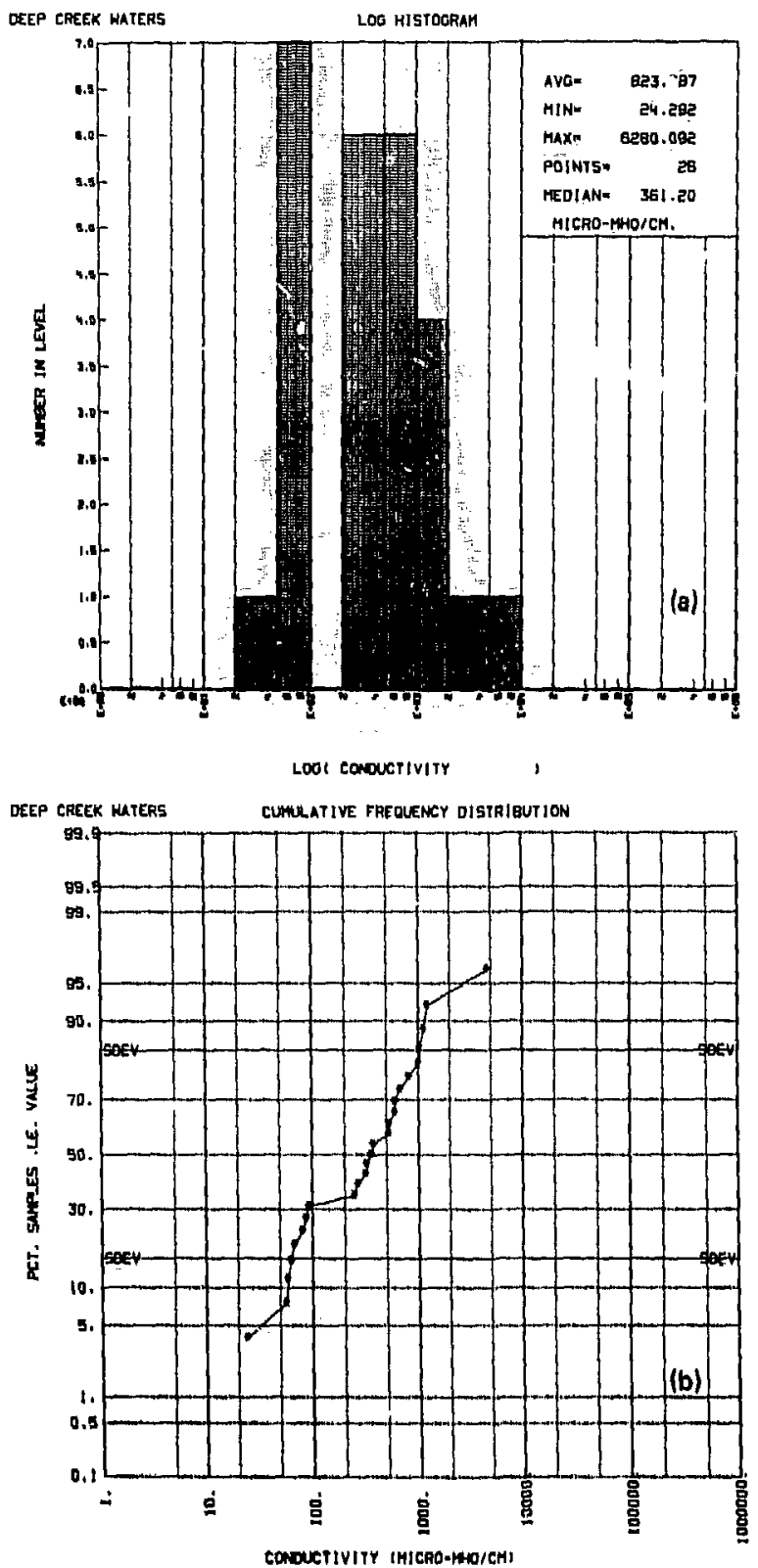

FIG. A-4, Hlstogram (a) and cumulative frequency distribution (b) of theld conductivities for water samples plotted in Overlay $\mathbf{I C}$. 

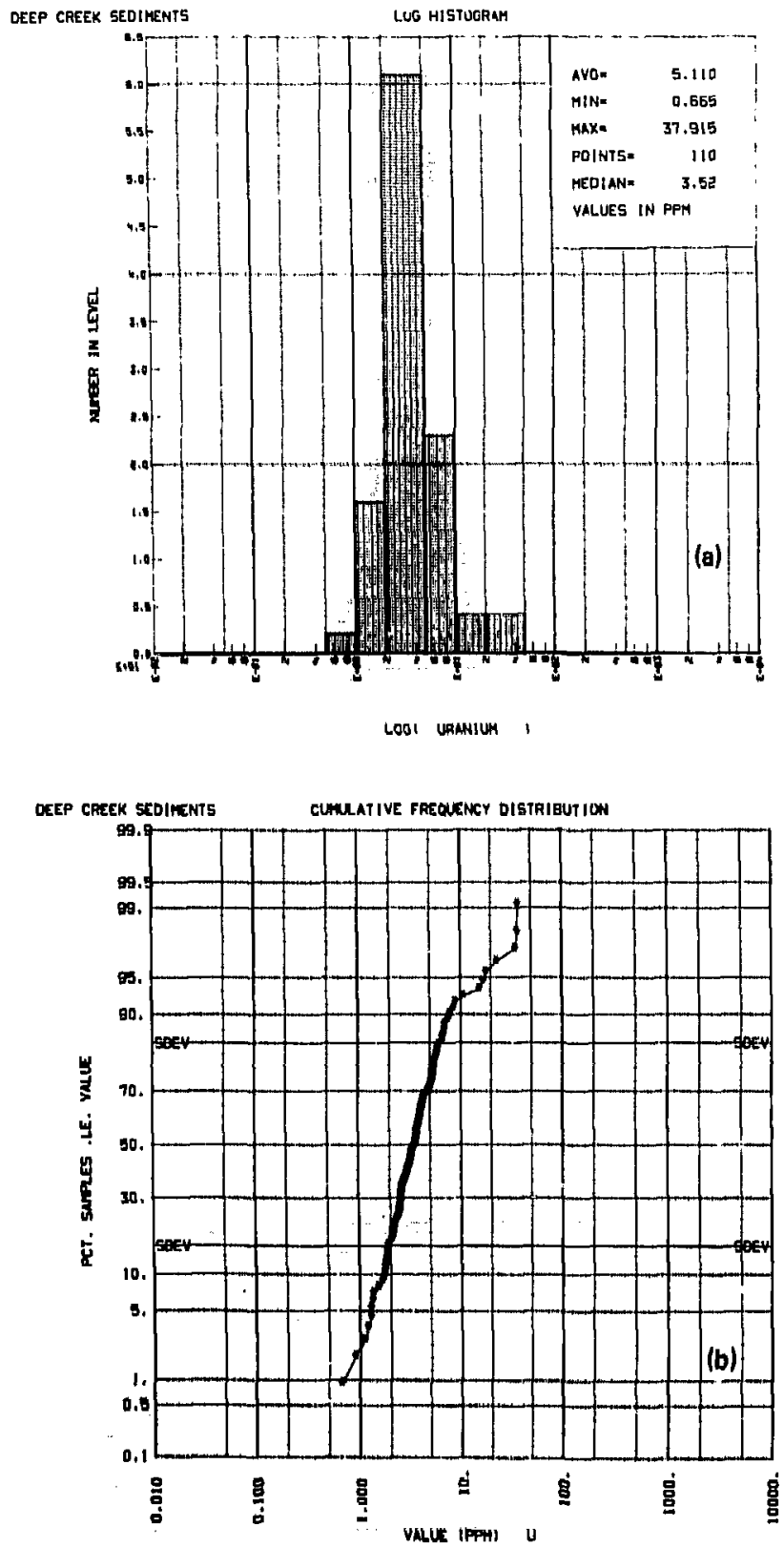

FIG. A-S. Histogram (a) and cumulative frequency distribution (b) of vranium concentration for sediment samples plotted on Overiny 28 . 

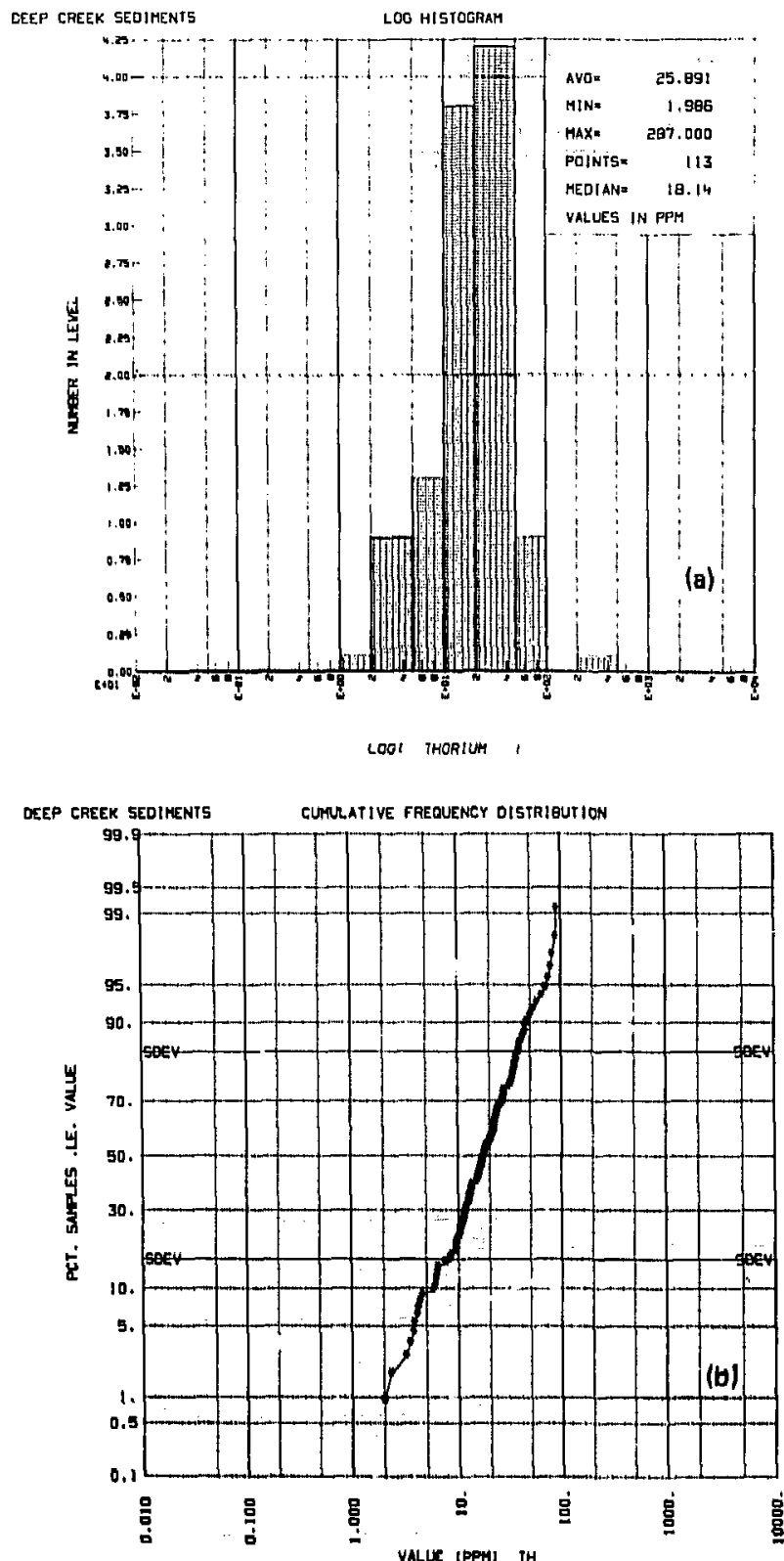

FIG. A-6. Histogram (a) and cumulative frequency distrlbution (b) of thorium concentrations for sediment samples plotted on Overlay $\mathbf{2 C}$. 


\section{DATA DEFINITIONS}

This section presents a brief explanation of the columnar entries for the hardcopy and microfiche data tables.

Blanks in the data tables indicate no measurement available. Detection limits for INAA determinations are given in the tex.. Emission spectrometry detection limits are indicated in the data tables by the "less than" sign $(<)$.

\section{DOE SAMPLE NUMBER}

Each analyzed field sumple is assigned a DOE number consisting of 28 characters. Five charucters (dashes) are used to delineate the number of subdivisions. The subdivision assignments are:

Position

$1-2$

$26-28$
ST,

LAT,

LONG,

L,

TY,

RPL,
Doscription

Stato, the two-digit Fodoral Informution Processing Standard (FIPS) designated for the state corresponding to the sample site lacation $(A Z=04, C A=06, I D=16, N V=32$, $O R=41, U T=49, W A=53$ )

Latitude of site in decinal degrees.

Longitude of site in decimal degrees.

Originating laboratory ( 1 = LLL)

DOE Samplr Type, A two-digit code describing the sumple source, medium, and overall geochemical treatment (field and laboratory) prior to analysis. See DOE Sample Type Numbors below for speaific assigninents.

Replication Code. Threc-digits used to distinguish between samples from the same site. The first indicates sample type ( $1=$ sediment, $2=$ vater), the second identifies the field duplicate, and the third identifies analytical splits.

\section{TY, DOE, SAMPLE TYPE NUMBERS}

Number

01

02

03

04

06

07

08

09

Spring water sample untreated.

River or stream water sample untreated.

Well water sample untreated.

Lake or reservoir water sample untreated.

Spring water stmple filtered through a $0.45-\mu \mathrm{m}$ membrane filter and acidified to a $\mathrm{pH}$ of $\leq 1$ with high purity nitric acid $\left(\mathrm{HNO}_{3}\right)$.

River or stream water sample filtered through a $0.45-\mu \mathrm{m}$ membrane filter and acidified to a $\mathrm{pH}$ of $\leq 1$ with high purity nitric acid $\left(\mathrm{HNO}_{3}\right)$.

Well water sample filtered through a 0.45 - $\mathrm{\mu m}$ membrane filter and acidified to a $\mathrm{pH}$ of $\leq 1$ with high purity nitric acid $\left(\mathrm{HNO}_{3}\right)$.

Lake or reservoir water sample filtesed through a $0.45-\mu \mathrm{m}$ membrane filter and acidified to a $\mathrm{pH}$ of $\leq 1$ with high purity nitric acid $\left(\mathrm{HNO}_{3}\right)$.

Spring water sample filtered through a $0.45 \mu \mathrm{m}$ membrane filter.

River or stream water sample flltered through a $0.45-\mu m$ membrane filter.

Well water sample filtered through a $0.45-\mu m$ memorane filter.

Lake or resswoir water sample filtered through a $0.45-\mu \mathrm{m}$ membrane filter.

Wet sediment sample dried at $110^{\circ} \mathrm{C}$ and sleved to the reported particle size range.

Lake or reservoir sediment sample dried at $110^{\circ} \mathrm{C}$ and sieved to the reported particle size range,

Dry sediment simple dried at $110^{\circ} \mathrm{C}$ and sieved to the reported particle size range.

Picya sediment sample taken by hand auger over the reported depth, dricd at $100^{\circ} \mathrm{C}$,

and crushed to a fine powder.

Rock sample crushed and sleved to less than $250 \mu \mathrm{m}$. 


\section{TEMPERATURE}

Temperature. Measurement of water temperature in situ by mercury thermometer to nearest $0,1^{\circ} \mathrm{C}$.

pH

Activity in $\mathrm{pH}$ units, reported to nearest $0,1 \mathrm{pH}$ unit at ambient water temperature.

\section{SP COND}

Specific condustance. Meusurements in situ with a commercial conductivity meter, Reported as conductance in micromhos per $\mathrm{cm}(\mu \mathrm{mho} / \mathrm{cm})$ normalized $1025^{\circ} \mathrm{C}$.

\section{PHENO-ALK}

Phenolphthalein alkulinity. Measurement by titration with standard sulphuric acid to a phenolphthalein indicator endpoint $(\mathrm{pH}=8.3)$. Reported as an equivalent amount of $\mathrm{CaCO}_{3}$ in $\mathrm{mg} / \mathrm{l}$, minimum detection $20 \mathrm{mg} / \mathrm{l}$.

\section{TOT-ALK}

Total alkalinity. Measurement by titration with statidard sulphuric acid to a bromcresol greenmethyl red indicator endpoint ( $\mathrm{pH}=4.8$ ). Reported as an equivalent amount of $\mathrm{CaCO}_{3}$ in $\mathrm{mg} / \mathrm{l}$, minimum detection $20 \mathrm{mg} / \mathrm{l}$.

\section{POSSIBLE CONTAMINATION}

The major possible contaminant types are indicated according to the following a de: 1 . none; 2 . mining; 3. agricultural; 4. industrial; 5. sewage; 6. power generation; 7. urban; 8. recreation; 9 . other.

\section{URANIUM}

The trace element concentration of uranium in the sample as determined by DNC, is given in parts per billion (ppb) by weight for waters and in parts per million (ppm) by weight for sediments. Where DNC values are not available, INAA determinations have besn substituted and flagged with an usterisk("). The error column contains a statistical estimate of measurement uncertainty expressed as a percentage of the concentration.

\section{OTHER ELEMENTS}

The trace element concentration of each element in the sumple is given in parts per billion (ppb) by weight for waters and in parts per million (ppm) by weight for seditments. The error column (ERR) gives a numerical estimate (expressed in trace-element concentration units) of the uncertainties associated with quanlizution of the elemental concentration. 


\section{APPENDIX B}

NUMERICAL RESULTS OF RECONNAISSANCE SURVEY 
SITE

DOF SARPLE MUREER--

PARIICLE SIZE POS

D-REF

LRANI DNIONC, THOAILMINMA]

7344 49-39.6638-113.9165-[1-70-100 02/03/77 STREAM

7345 49-39.5791-113.9514-1-70-100 02/04/77 STREAM

7346 49-39.5791-113.9514-1-72-101

15601 32-39.7276-118.9346-1-72-100

15602 茫-39.7265-118.9369-1-72-100

15602 32-39.7265-118.9369-1-72-100

15603 32-39.7265-119.9392-1-72-100

15603 32-39.7265-118.9392-1-77-50

5603 32-39.7265-118.9392-1-77-50

15604 32-39.7274-118.9427-1-72-100

15604 32-39.7ट74-118.9427-1-77-500

$1560532-39$. $7274-119.9451-1-72-100$

15605 32⿰-39.7274-119.9451-1-77-500

15606 32-39.7228-119.9519-1-72-100

15605 32-39.7228-118.9519-1-77-501

15607 3e-39.7218-118.9531-1-72-100

Is507 32-39.7218-118.9531-1-77-500

I509 3e-70 $7000-110.054-1-77-500$

15609 32-39.7210-118.9554-1-72-100

15609 32-39.7219-1 18.9554-1-77-50

15610 32-39.7263-118.9544-1-72-100

15610 32-39.7263-116.9544-1-77-500

15611 3e-39.7273-116.9497-1-72-100

15611 32-39.7273-118.9497-1-77-500

15611 32-39. $7273-118.9497-1-77-501$

15612 32-30.70

15.13

15613 30-70 $7291-1$.

1 5 14 32-39-7327-118.9499-1-72-100

15614 3e-39.7377-118.9499-1-77-500

15615 3z-39.7336-118.9488-1-72-100

15615 32-39.7336-118.9480-1-77-500

5615 32-39.7334-118.9468-l-77-50]

15616 32-39.7346-119.9476-1-72-100

15516 32-59.7348-118.9476-1-77-500

15617 32-39.6169-118.9e16-1-72-100

15617 32-39.6169-118.9816-1-77-500

15619 32-39.6159-118.9939-1-72-100

150 39.

15519 z=-39.

15리

$15 \times 00$ 32-39.6149-110.9997-1-77-500

I562: 32-39.6054-118.9977-1-72-100

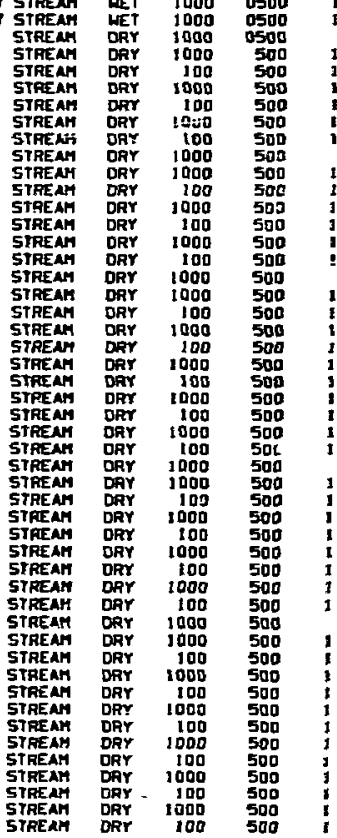

\begin{tabular}{|c|c|c|c|}
\hline $\begin{array}{l}\bar{E} .68 \\
2.74 \\
2.09 \\
6.55 \\
0.07 \\
7.05 \\
0.78 \\
7.80 \\
0.06\end{array}$ & $\begin{array}{l}1.29 \\
1.46 \\
1.44 \\
1.20 \\
5.43 \\
1.10 \\
5.07 \\
1.16 \\
5.07\end{array}$ & $\begin{array}{l}10.45 \\
13.75 \\
12.25 \\
24.89 \\
26.61^{50 .} \\
23.23\end{array}$ & $\begin{array}{l}1.45 \\
1.35 \\
1.18 \\
1.73 \\
1.88 \\
1.72\end{array}$ \\
\hline $\begin{array}{l}6.14 \\
0.05 \\
5.20 \\
0.09 \\
5.23 \\
0.09\end{array}$ & $\begin{array}{l}1.19 \\
5.69 \\
1.19 \\
5.04 \\
1.18 \\
6.76\end{array}$ & $\begin{array}{l}24.56 \\
22.26 \\
22.30\end{array}$ & $\begin{array}{l}1.56 \\
1.24 \\
1.28\end{array}$ \\
\hline $\begin{array}{l}6.10 \\
0.07 \\
5.49 \\
0.10 \\
6.46 \\
0.07 \\
6.37 \\
0.11 \\
6.39 \\
0.07\end{array}$ & $\begin{array}{l}1.19 \\
5.82 \\
1.20 \\
4.43 \\
1.20 \\
5.69 \\
1.17 \\
4.21 \\
1.17 \\
7.32\end{array}$ & $\begin{array}{l}21.16 \\
22.99 \\
20.29 \\
23.92 \\
22.11\end{array}$ & $\begin{array}{l}1.50 \\
1.74 \\
1.82 \\
1.43 \\
1.27\end{array}$ \\
\hline $\begin{array}{l}6.20 \\
0.07 \\
5.22 \\
0.08 \\
6.30 \\
0.10 \\
7.23 \\
0.10\end{array}$ & $\begin{array}{l}1.38 \\
5.47 \\
1.20 \\
5.34 \\
1.20 \\
1.63 \\
1.16 \\
5.60\end{array}$ & $\begin{array}{l}25.08 \\
24.48 \\
21.00 \\
22.71\end{array}$ & $\begin{array}{l}1.60 \\
1.34 \\
1.59 \\
1.37\end{array}$ \\
\hline $\begin{array}{l}6.43 \\
0.10 \\
5.32 \\
0.17 \\
9.84 \\
0.36 \\
7.07 \\
.10 \\
7.03 \\
0.19 \\
.93 \\
0.08\end{array}$ & $\begin{array}{l}1.19 \\
4-61 \\
1.20 \\
3.38 \\
1.21 \\
2.33 \\
1.19 \\
4.70 \\
1.19 \\
3.14 \\
1.14 \\
5.25\end{array}$ & $\begin{array}{l}24.51 \\
28.70 \\
33.64 \\
31.68 \\
33.00 \\
44.47\end{array}$ & $\begin{array}{l}1.41 \\
1.56 \\
3.61 \\
2.07 \\
1.78 \\
2.39\end{array}$ \\
\hline
\end{tabular}


TABLE B-1. SEOIMENT ANALYSIS: DRY AND STREAT SITES

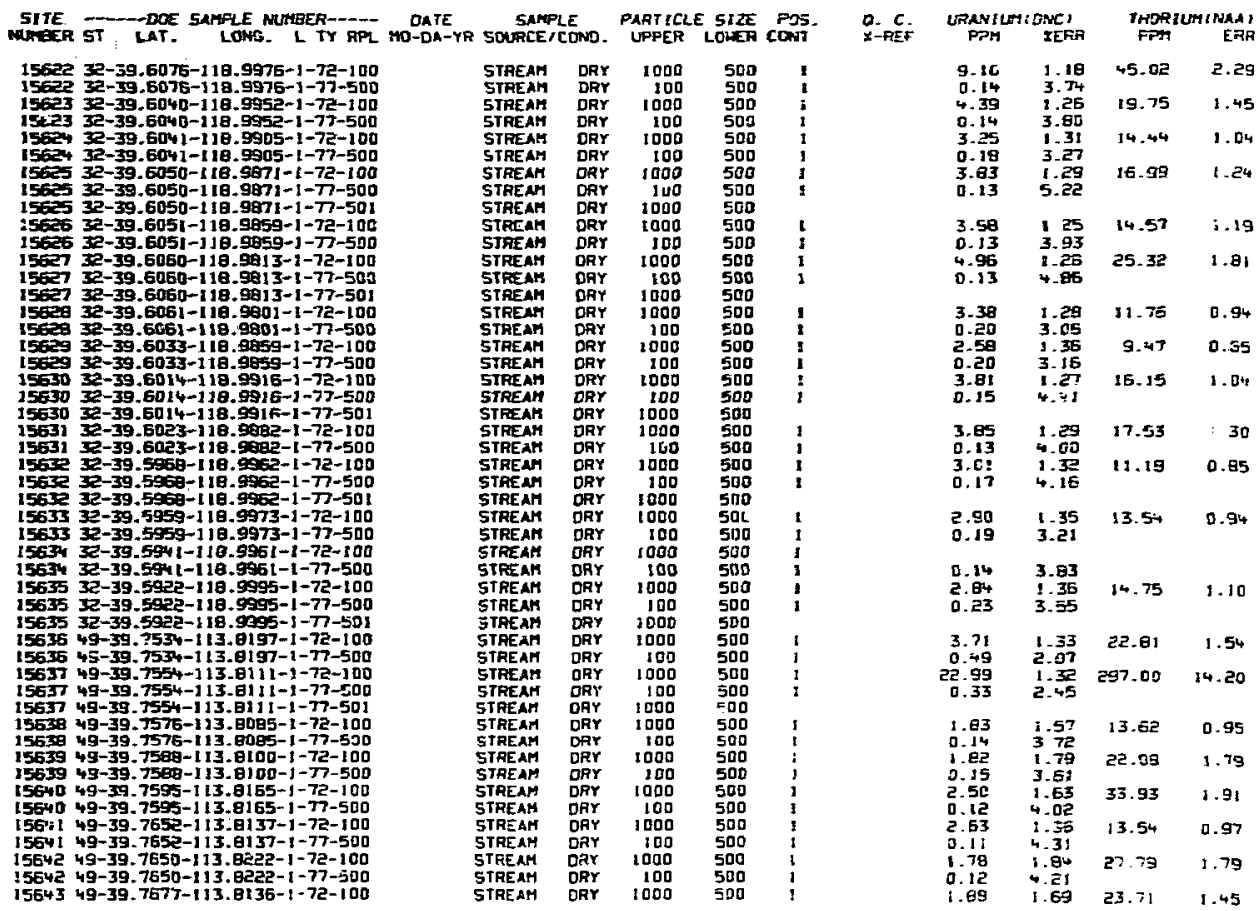




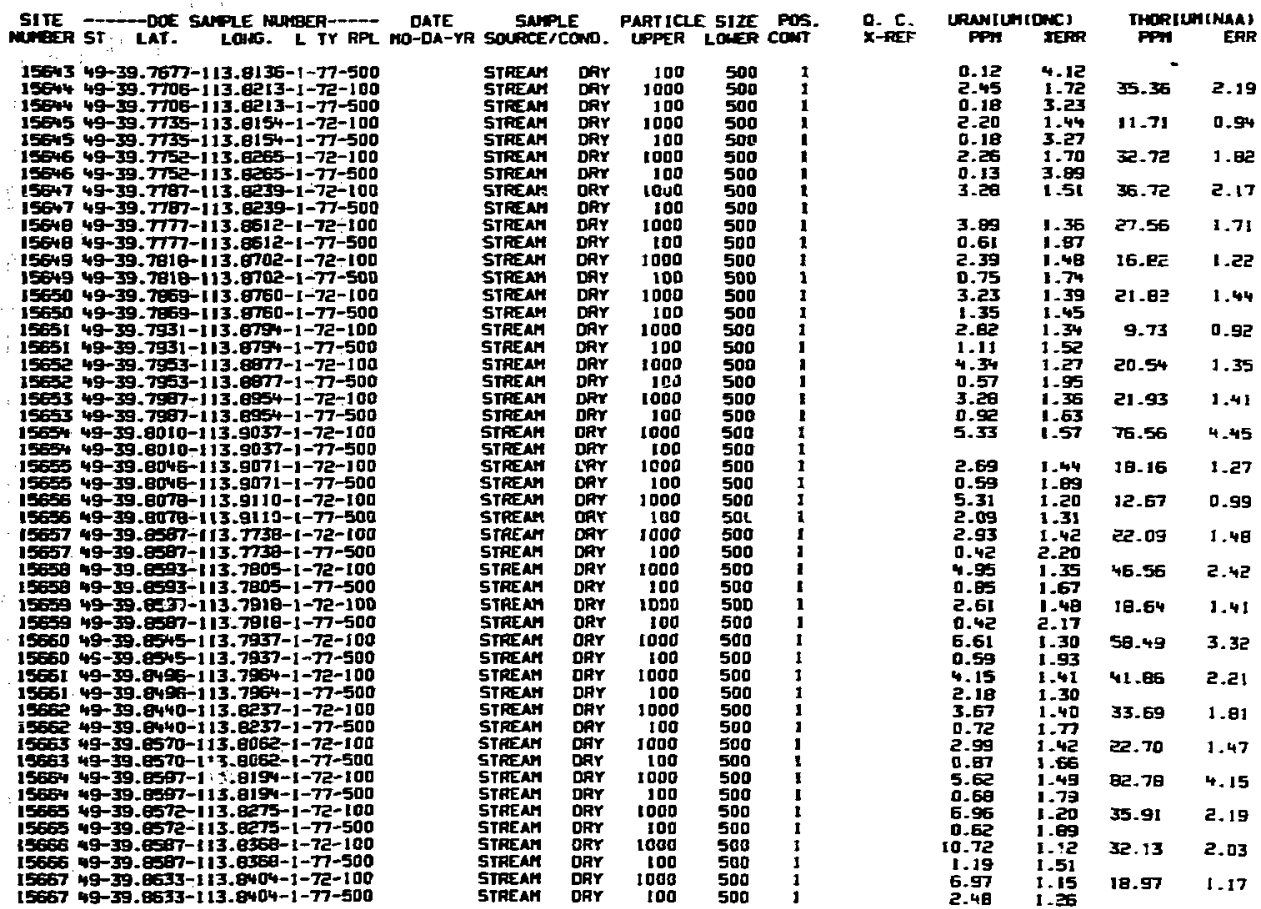


OEEP CREEK REPORT, LMLRENCE LIVERMORE L APCORTORT

TABLE B-1. SEOTMENT ANALYSIS: DRY ND STREAM SITES

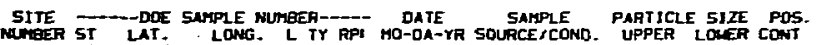

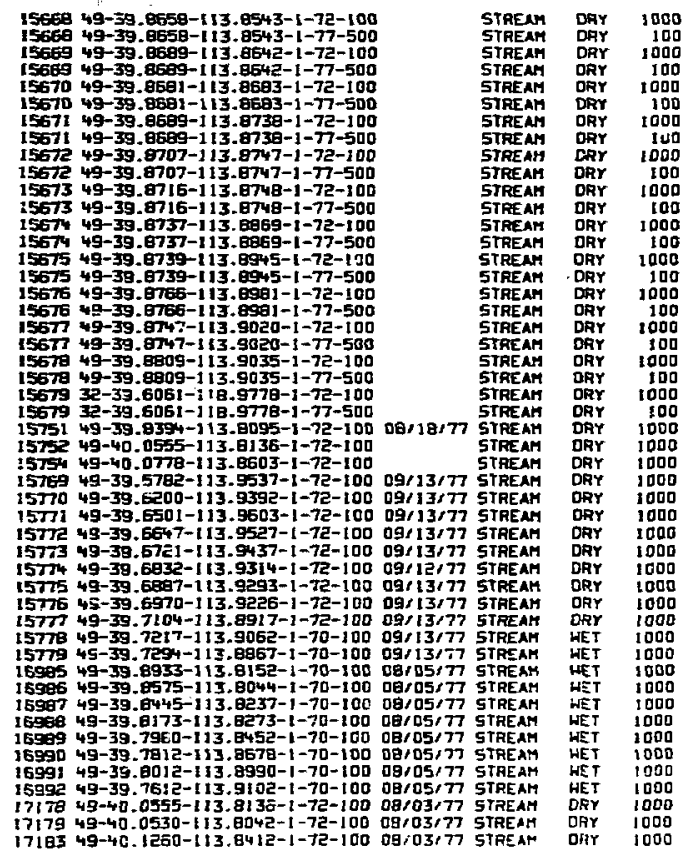

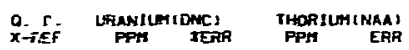

$\begin{array}{ll}500 & 3 \\ 500 & 1 \\ 500 & 1 \\ 500 & \vdots \\ 503 & 5 \\ 500 & 1 \\ 500 & 1 \\ 500 & 1 \\ 500 & 1 \\ 500 & 1 \\ 500 & 1 \\ 500 & 1 \\ 500 & 1 \\ 500 & 1 \\ 500 & 1 \\ 500 & 1 \\ 500 & 1 \\ 500 & \vdots \\ 500 & 1 \\ 500 & 1 \\ 500 & 1 \\ 500 & 1 \\ 500 & 1 \\ 500 & 1 \\ 0500 & 1 \\ 0500 & 1 \\ 0500 & 5 \\ 0500 & j \\ 0500 & 1 \\ 0500 & 1 \\ 0500 & 1 \\ 0500 & 1 \\ 0500 & 1 \\ 6500 & 2 \\ 0500 & 1 \\ 0500 & 1 \\ 0500 & 3 \\ 0500 & 1 \\ 0500 & 5 \\ 0500 & 5 \\ 0500 & 5 \\ 0500 & 9 \\ 0500 & 5 \\ 0500 & 5 \\ 0500 & 5 \\ 0500 & 9 \\ 0500 & \vdots \\ 0500 & 1 \\ 0500 & 5\end{array}$

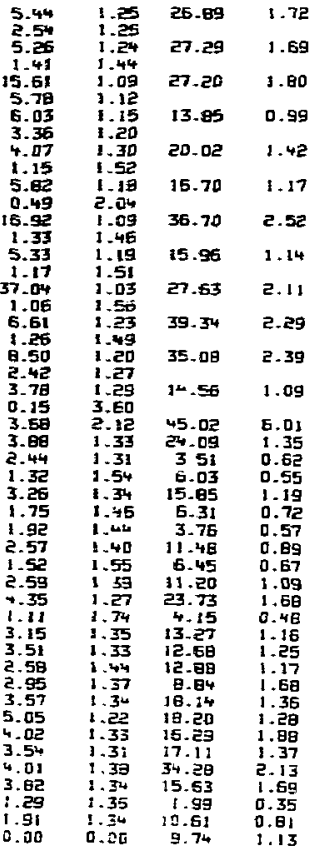




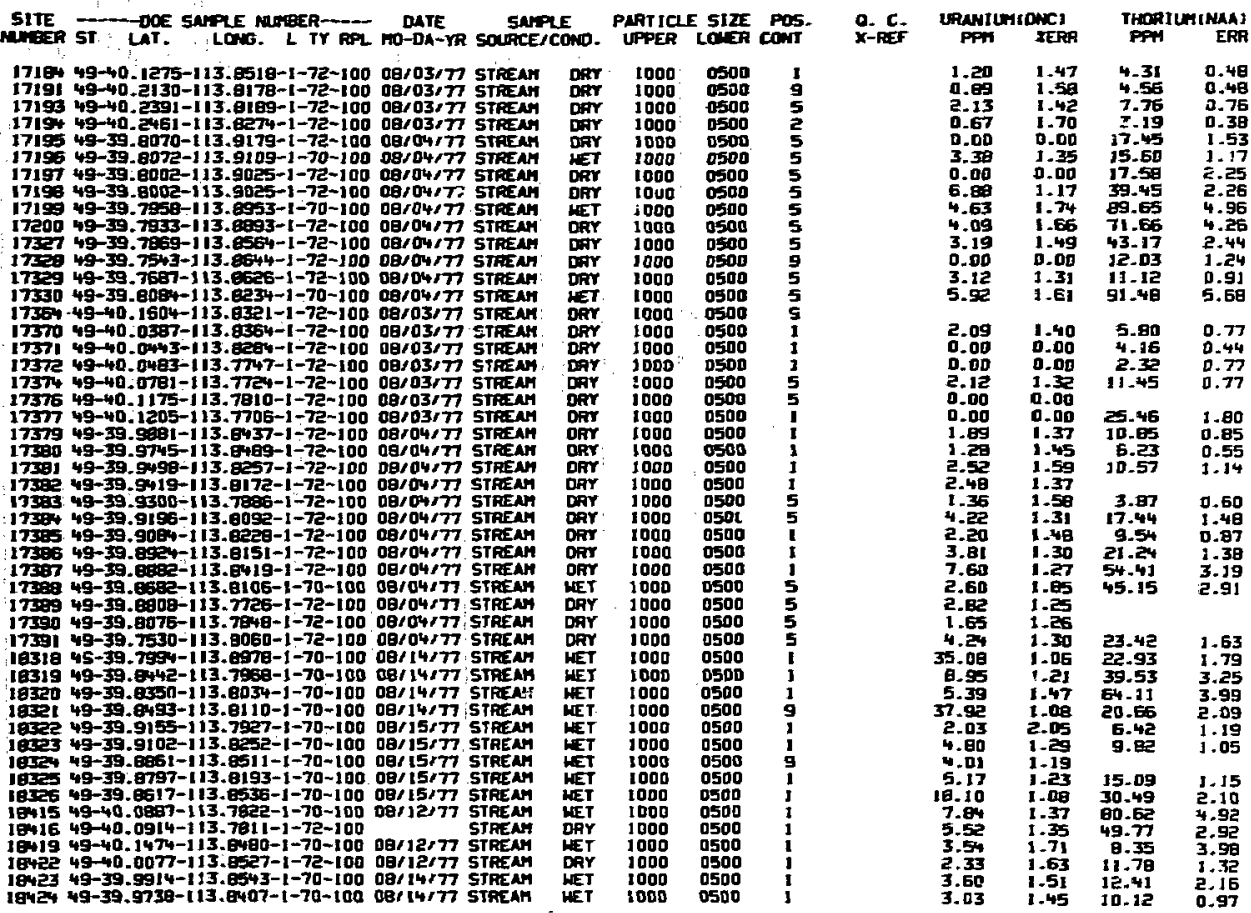




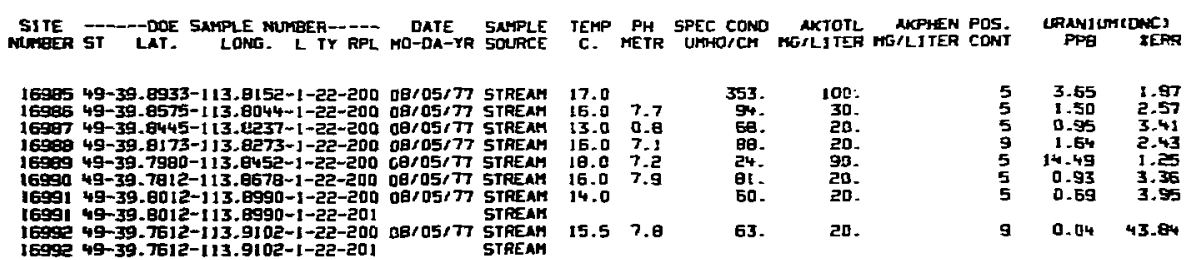




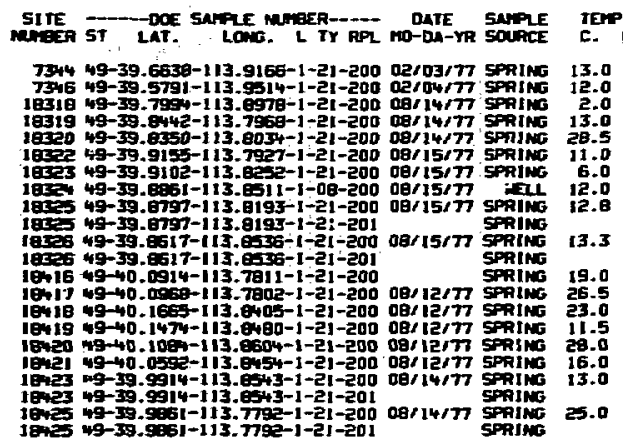

IEMP LELL

13.0

2.0

Q.5

\section{0}

12.0

13.3

19.0
26.5
23.0

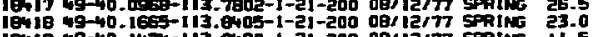

10419 9 $90.1474-113.0400-1-21-200$ 08112r77 SPRING 11.5

Iene1 $49-40.0502-113.6454-1-21-200$ 081 12177 5PRIN 16.0

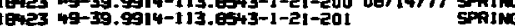

jeres 49-39.5951-113.7702-1-21-200 $00 / 14177$ SPRina 25.0
WEL TYPE

CELL PH SPEC CONO NOTOTL

$\begin{array}{ccc}7.5 & 1229 . & 140 . \\ 7.5 & 1127 . & 260 . \\ 7.8 & 57 . & 20 . \\ 7.5 & 1039 . & 180 . \\ 8.8 & 677 . & 160 . \\ 7.5 & 522 . & 200 . \\ 7.5 & 519 . & 220 . \\ 7.1 & 314 . & 140 . \\ 7.9 & 812 . & 240 . \\ 7.8 & 327 . & 120 . \\ 7.2 & 369 . & 120 . \\ 7.5 & 265 . & 200 . \\ 7.4 & 6260 . & 80 . \\ 6.5 & 243 . & 800 . \\ 7.3 & 4593 . & 200 . \\ 0.7 & 1001 . & 160 . \\ 7.7 & 501 . & 200 . \\ 7.3 & 600 . & 160 .\end{array}$


DEEP CREEK AEPOAT LAHRENCE LIVERMORE LABOHATOAT

TABLE B-J. HATER ANALYSIS: SPRINGG AND LELL SITES

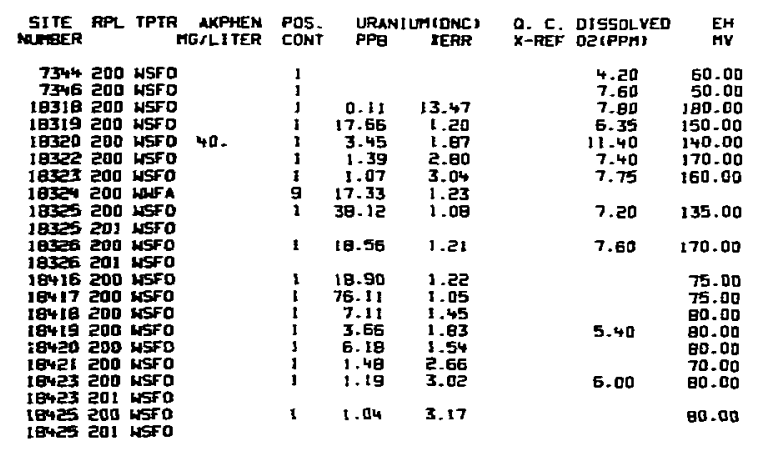




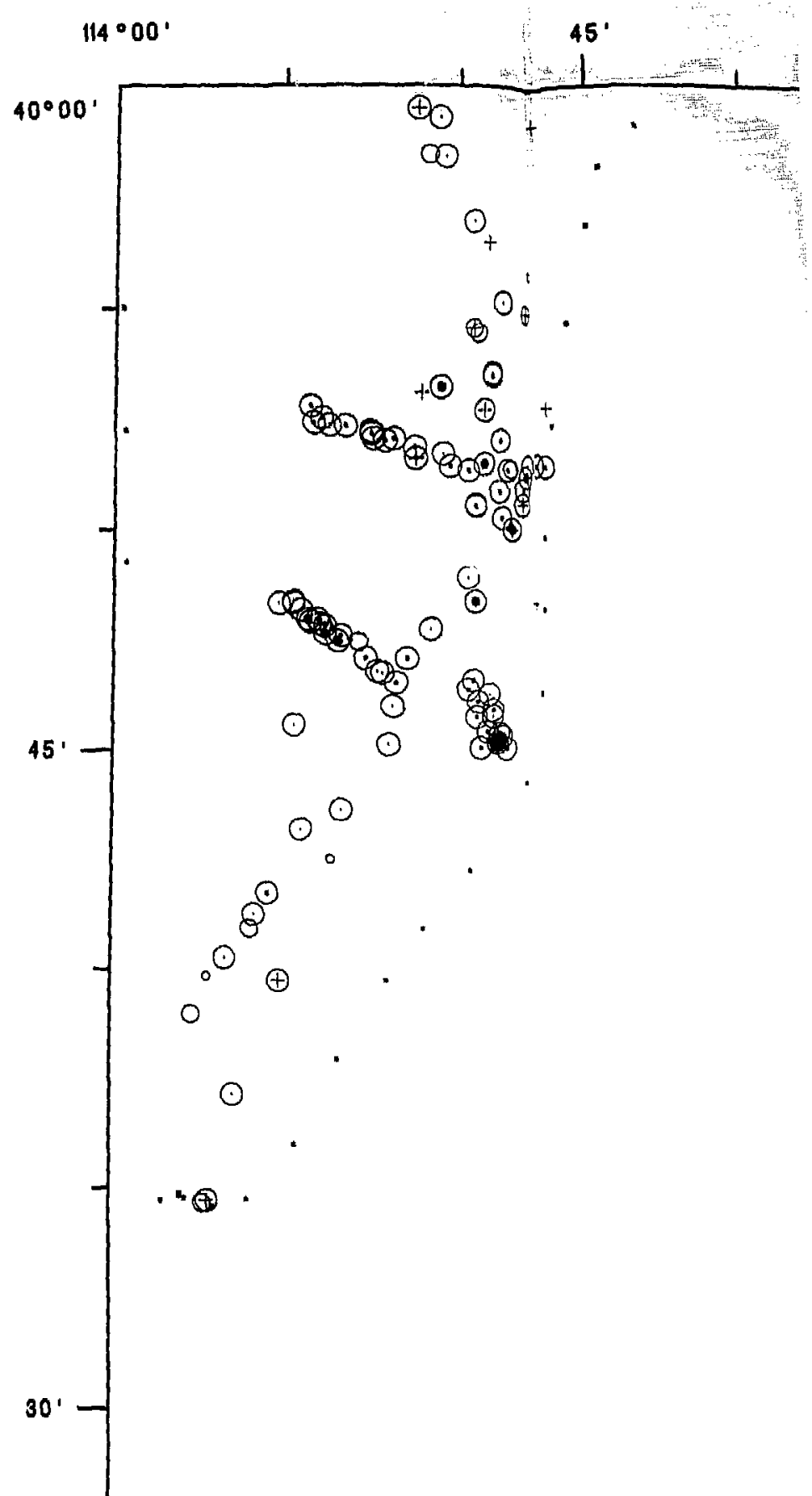




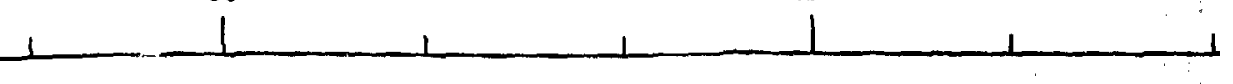




\section{DELTA} $113^{\circ} 00$ :

$45^{\circ}$

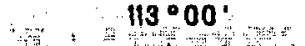

NJ 12

4 



.




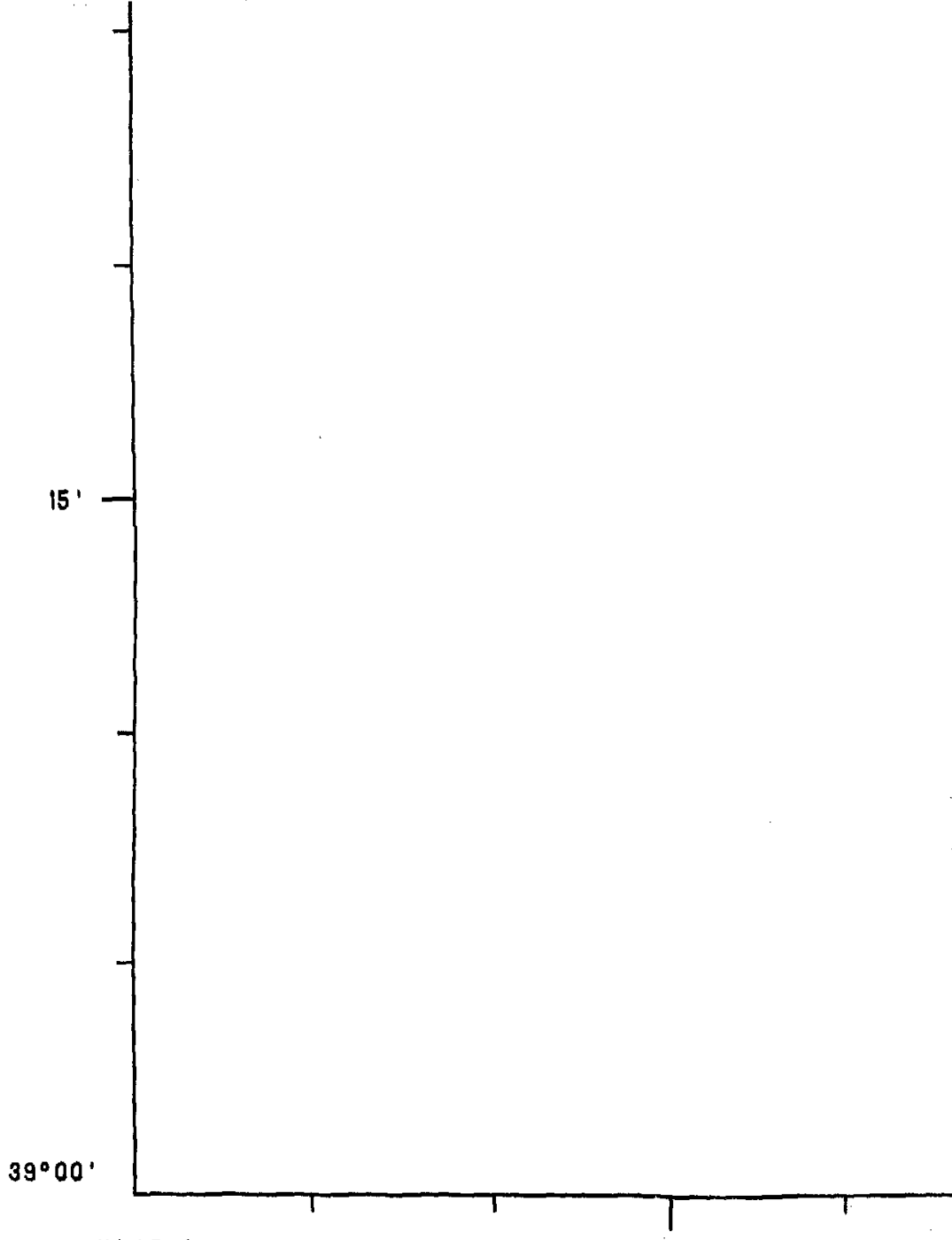

$114^{\circ} 00^{\prime}$

$45^{\prime}$

\section{SYMBOL EXPLANATION}

THORIUM(TOTALJCONCENTRATIONS

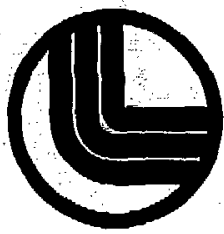

LAWRENCE LIVERMORE LABORATORY

UNIVERGITY OF OALIFORNIA

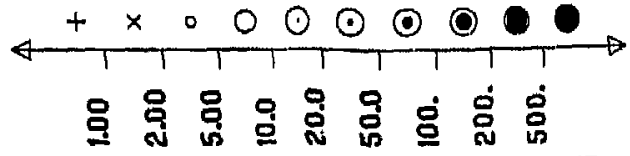

PARTS PER MILLIONCPPMJBY WEIGHT

$+\quad$ LESS THAN 1.00 PPM [OR NOT DETECTED] GREATER THAN 500. PPM 


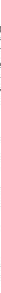

THORIUM ( TOTAL ) CO SEDIMENT 


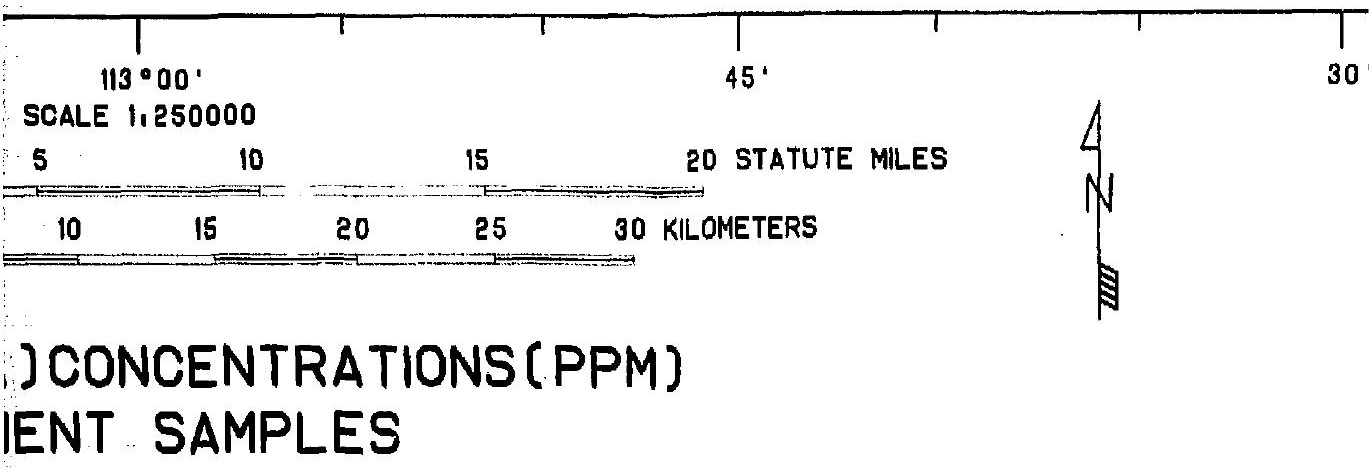




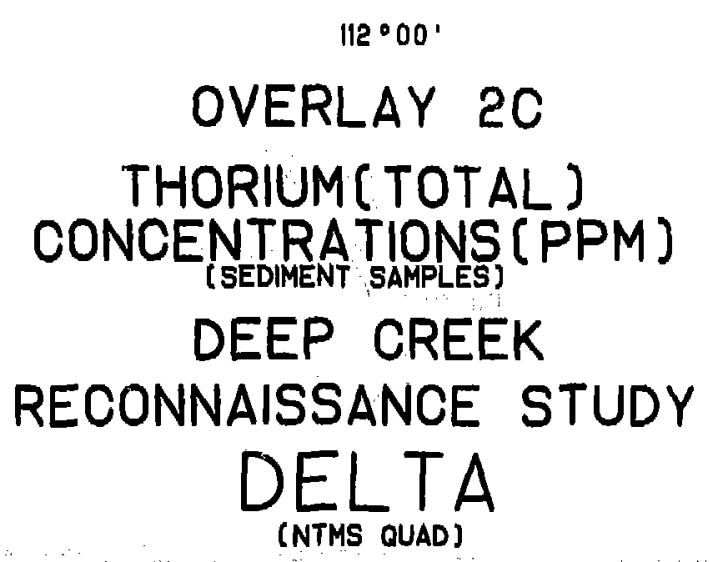


NJ 12-01

$45^{\prime}$ 
NJ 12-01

$30^{\circ}$

$112^{\circ} 00^{\circ}$

$1+1$ 


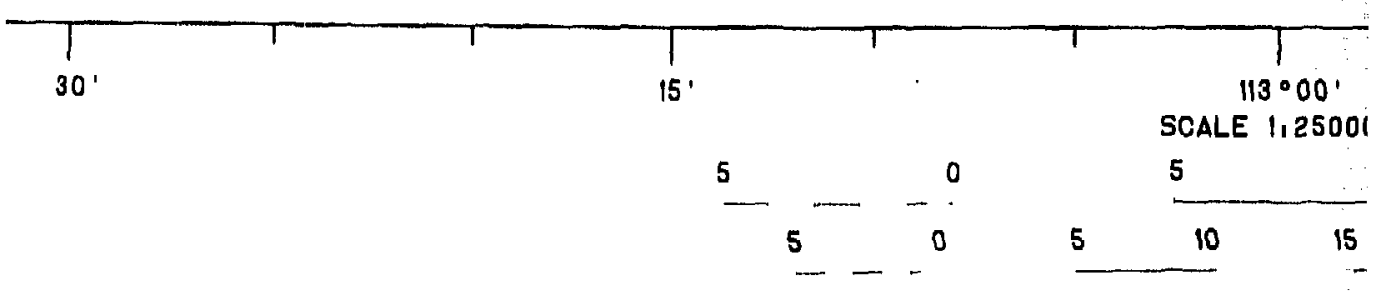




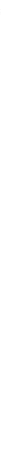




\section{OVERLAY IC}

CONDUCTIVITY $(\mu \mathrm{MHO} / \mathrm{CM})$ (WATER SAMPLES)

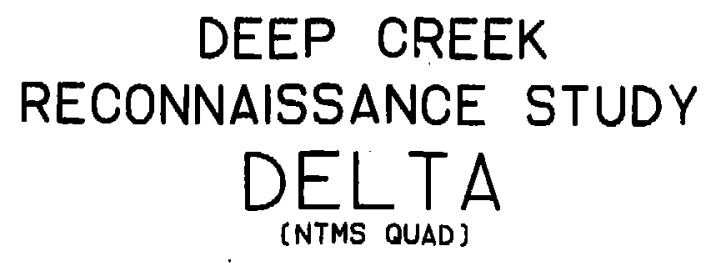




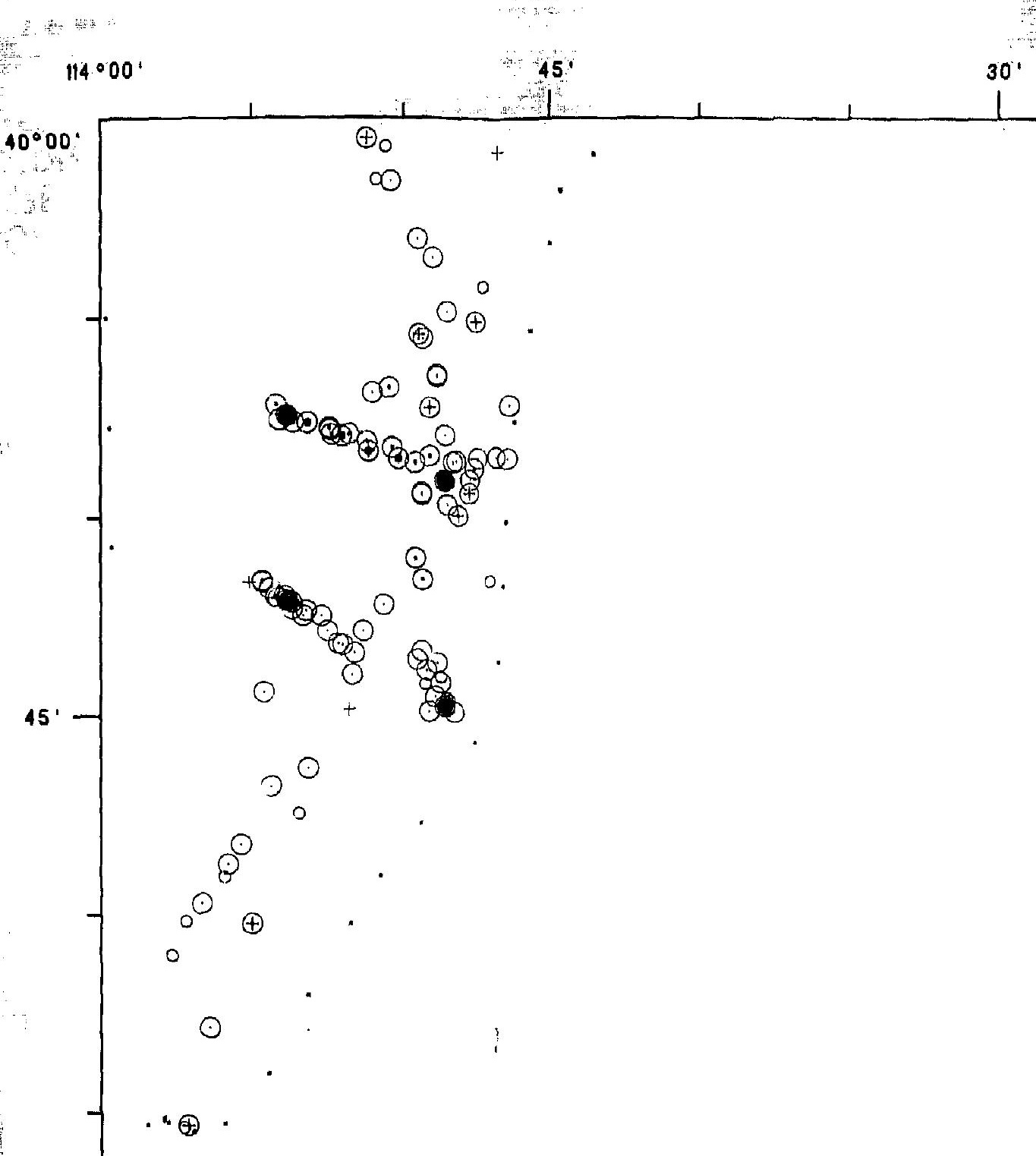


NJ 12-01

$$
45^{\prime}
$$$$
30^{\circ}
$$ 
NJ 12-01

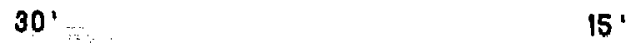

$112 \circ 00^{\circ}$

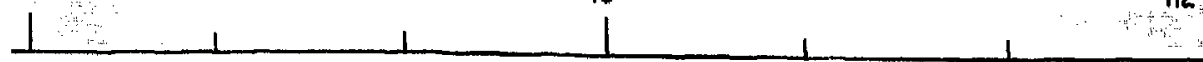




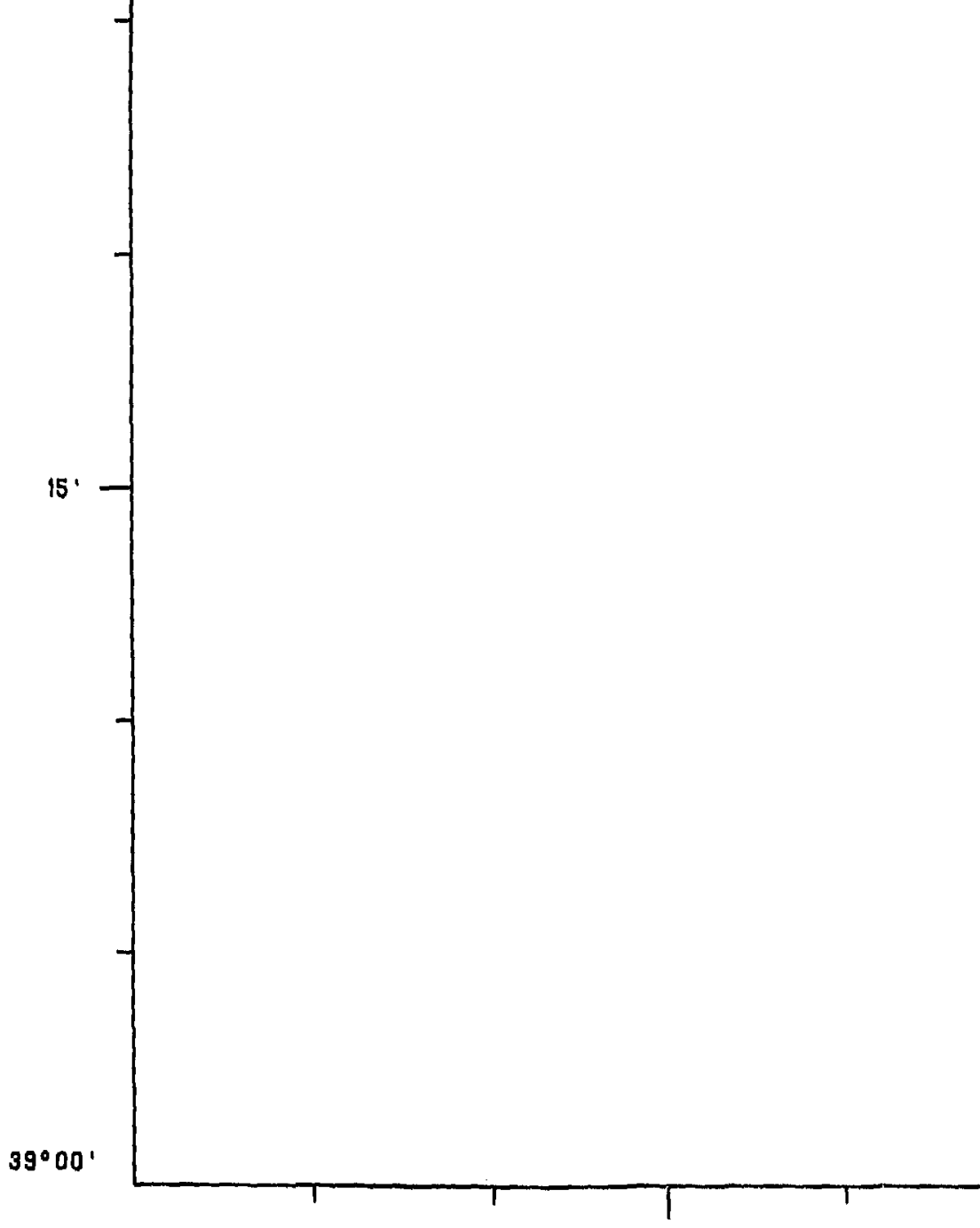

$114^{\circ} 00^{\circ}$

$45^{\prime}$

SYMBOL EXPLANATION URANIUM T TOTAL JCONCENTRATIONS

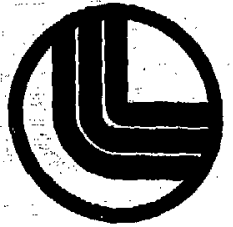

LAWRENCE LIVERMORE LABORATORY UNIVERSITY OF OALIFORNIA

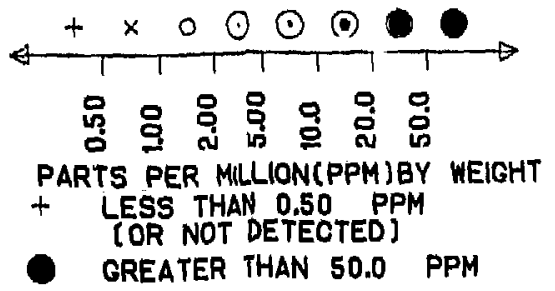

SER NO. LLL, NURE, HSSR 16,01,10 U 03/01/79 


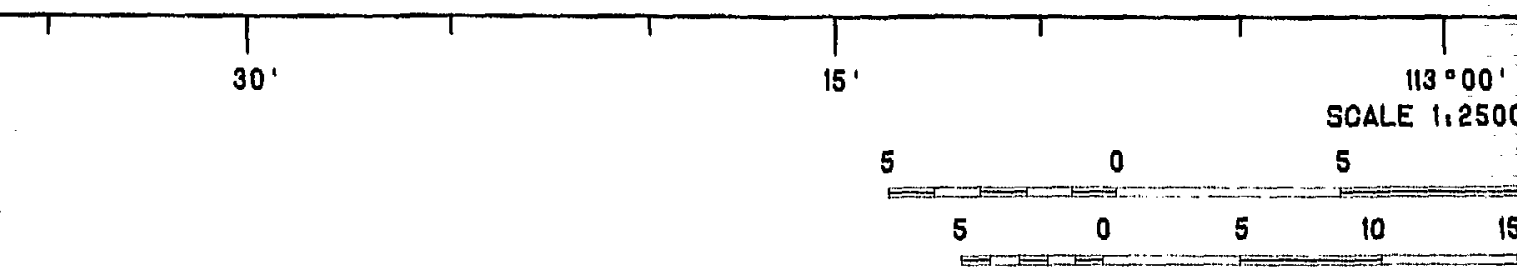

\section{URANIUM ( TOTAL ) CONCE SEDIMENT SA}




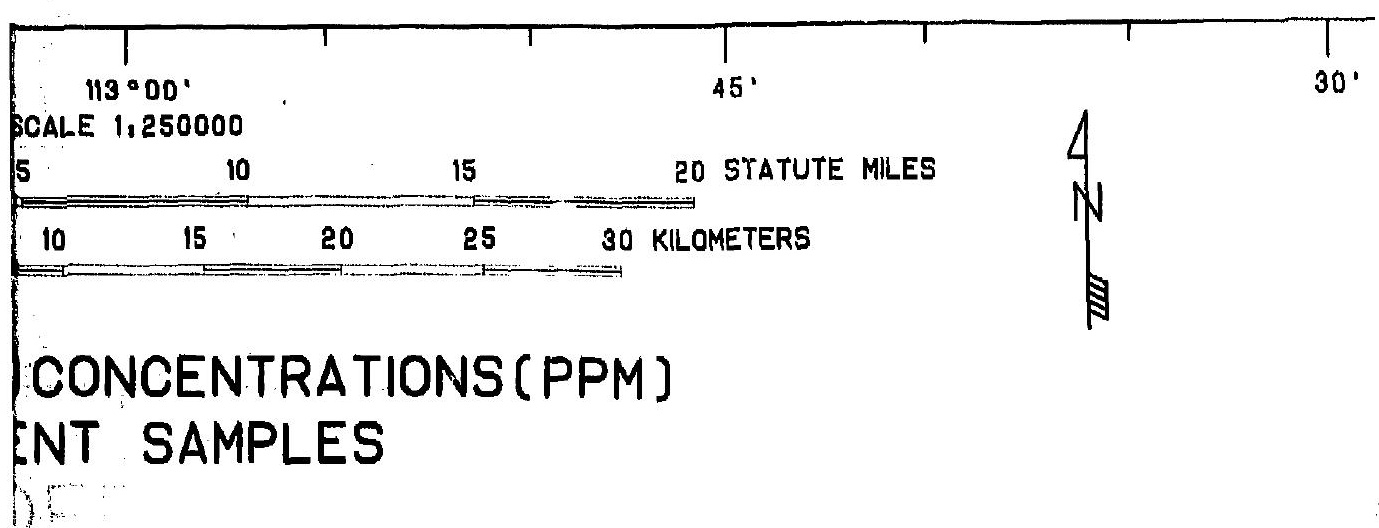




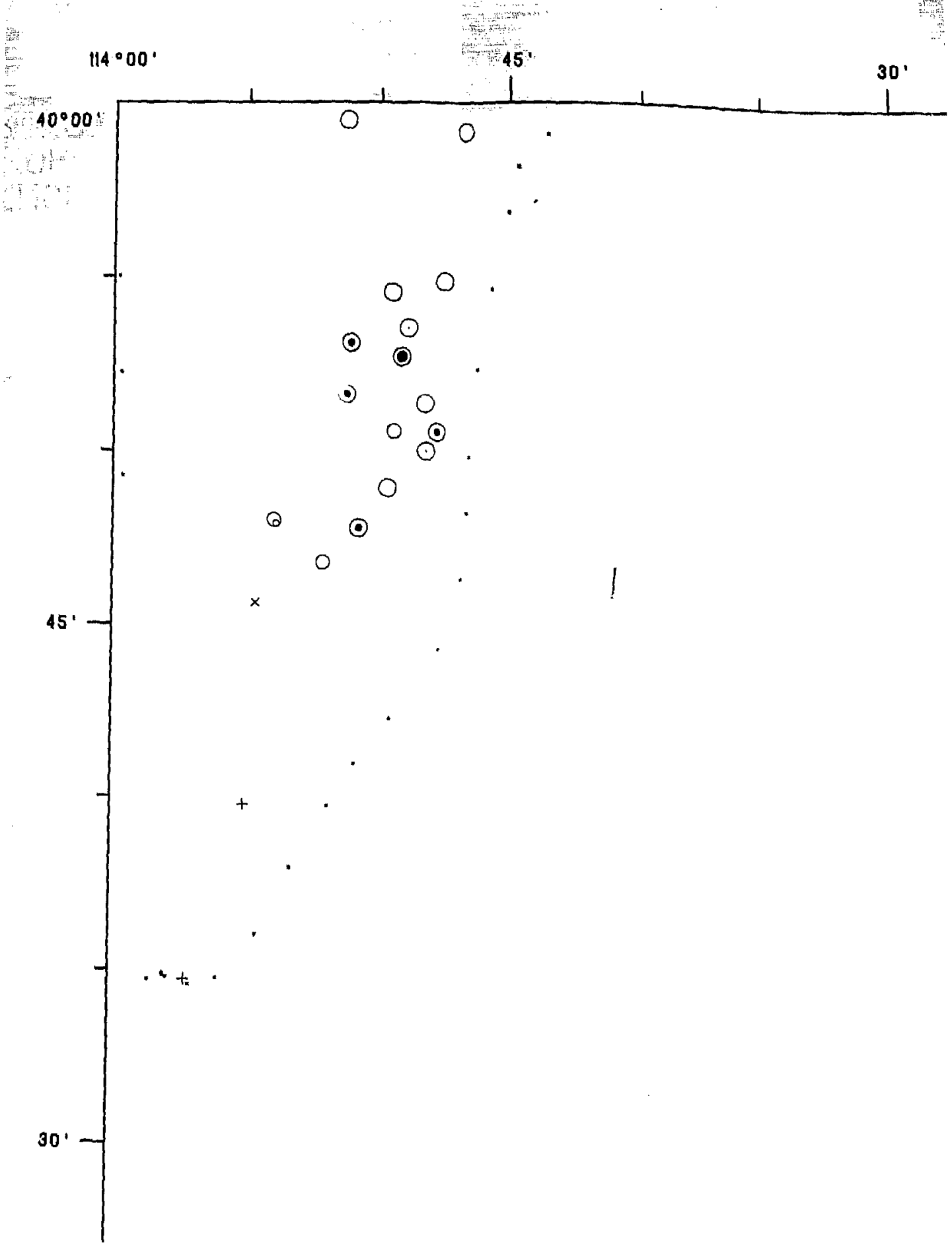


NJ 12-01

$45^{\circ}$

$30^{\circ}$

$1+1$

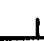


NJ 12-01

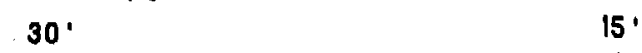

15 .

$112^{\circ} 00^{\circ}$

$\begin{array}{llll}1 & 1\end{array}$ 


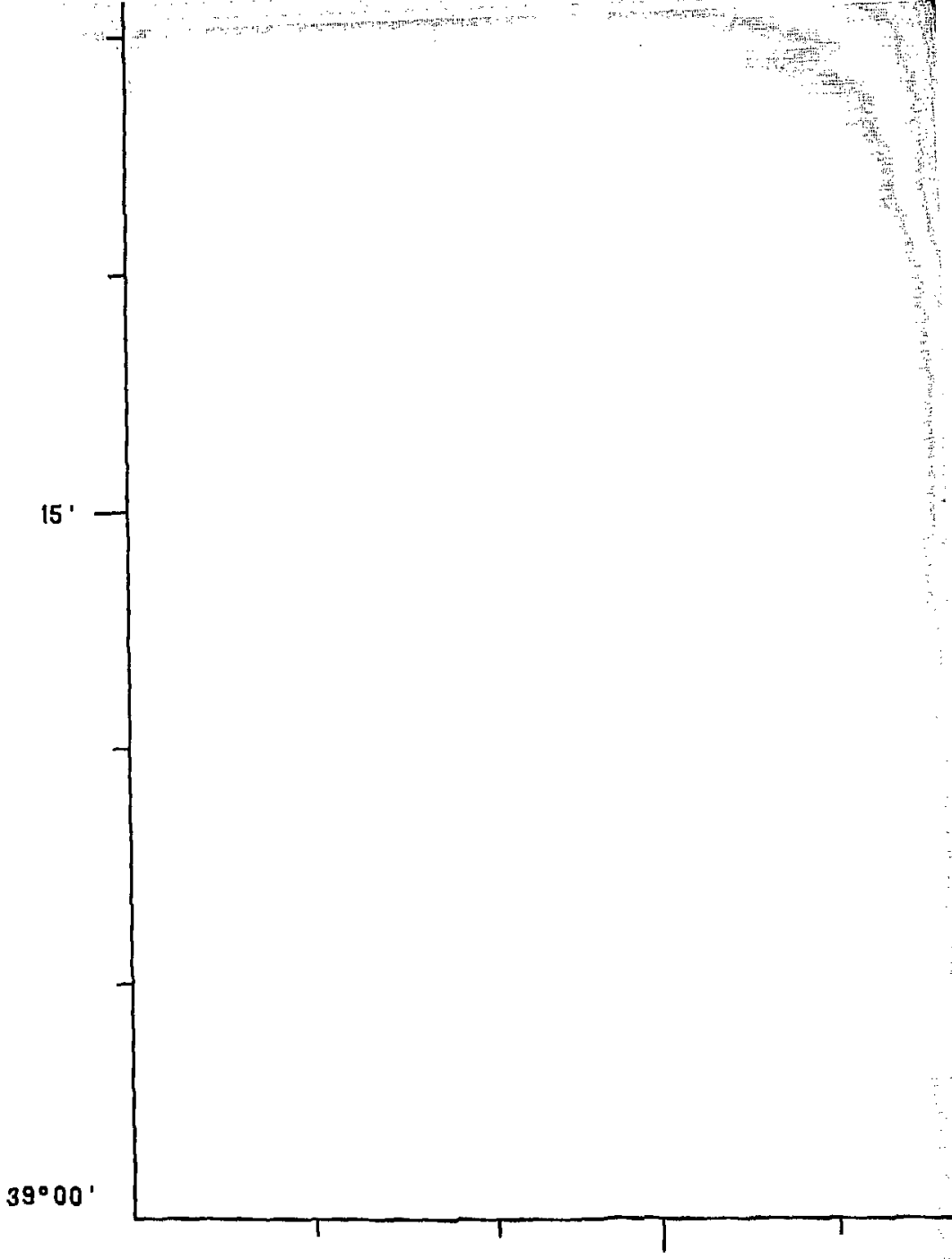

$114^{\circ} 00^{\circ}$

$45^{\prime}$

SYMBOL EXPLANATION URANIUMC TOTALJ CONCENTRATIONS

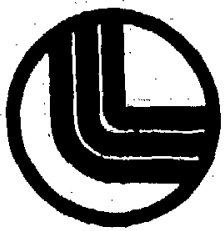

LAWRENCE LIVERMORE LABORATORY UNIVERSITY OF OALIFORNIA

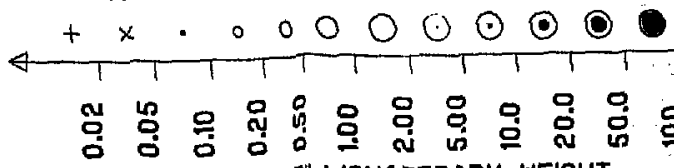
PARTS PER BLLLION(PPB)BY WEIGHT + LESS THAN 0.02 PPB (OR NOT DETECTED)

- gREATER THAN 100. PPB 


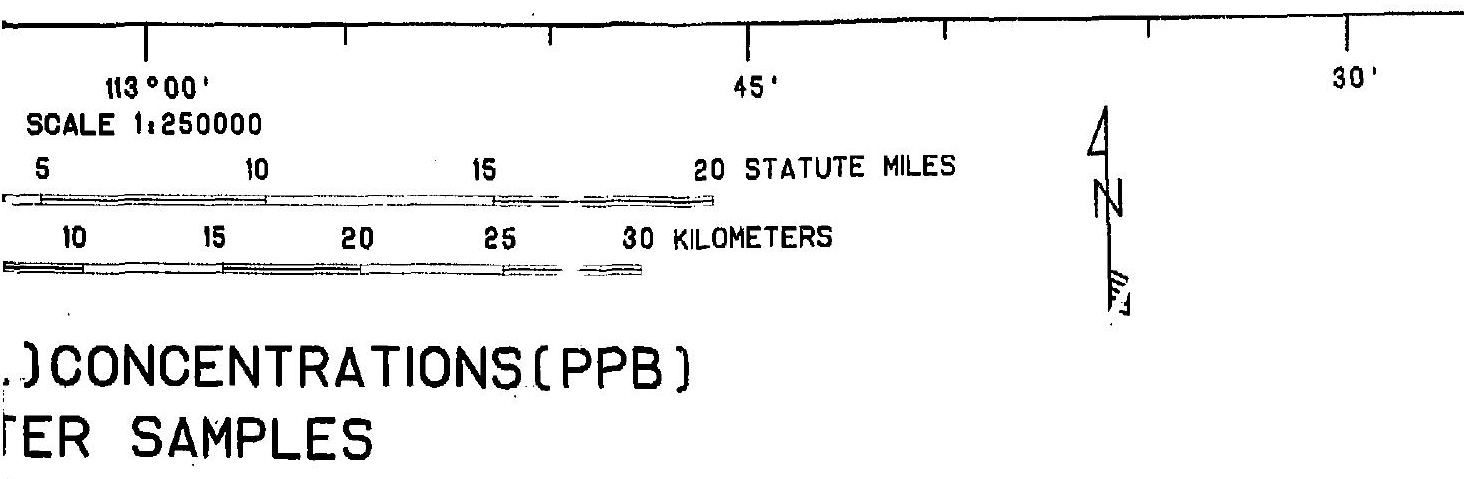




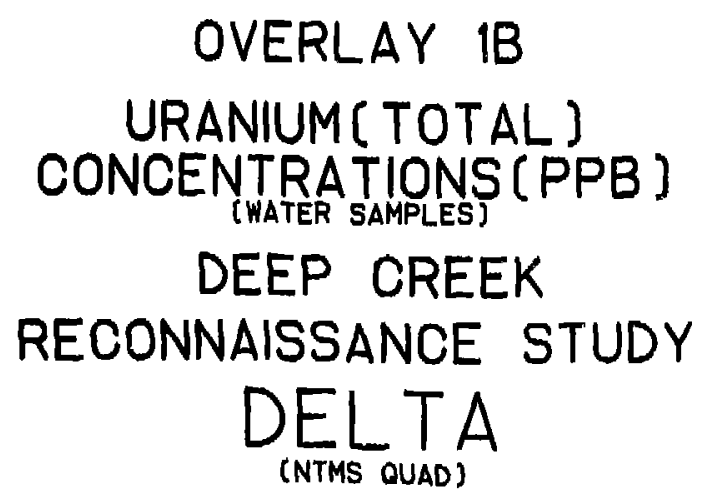




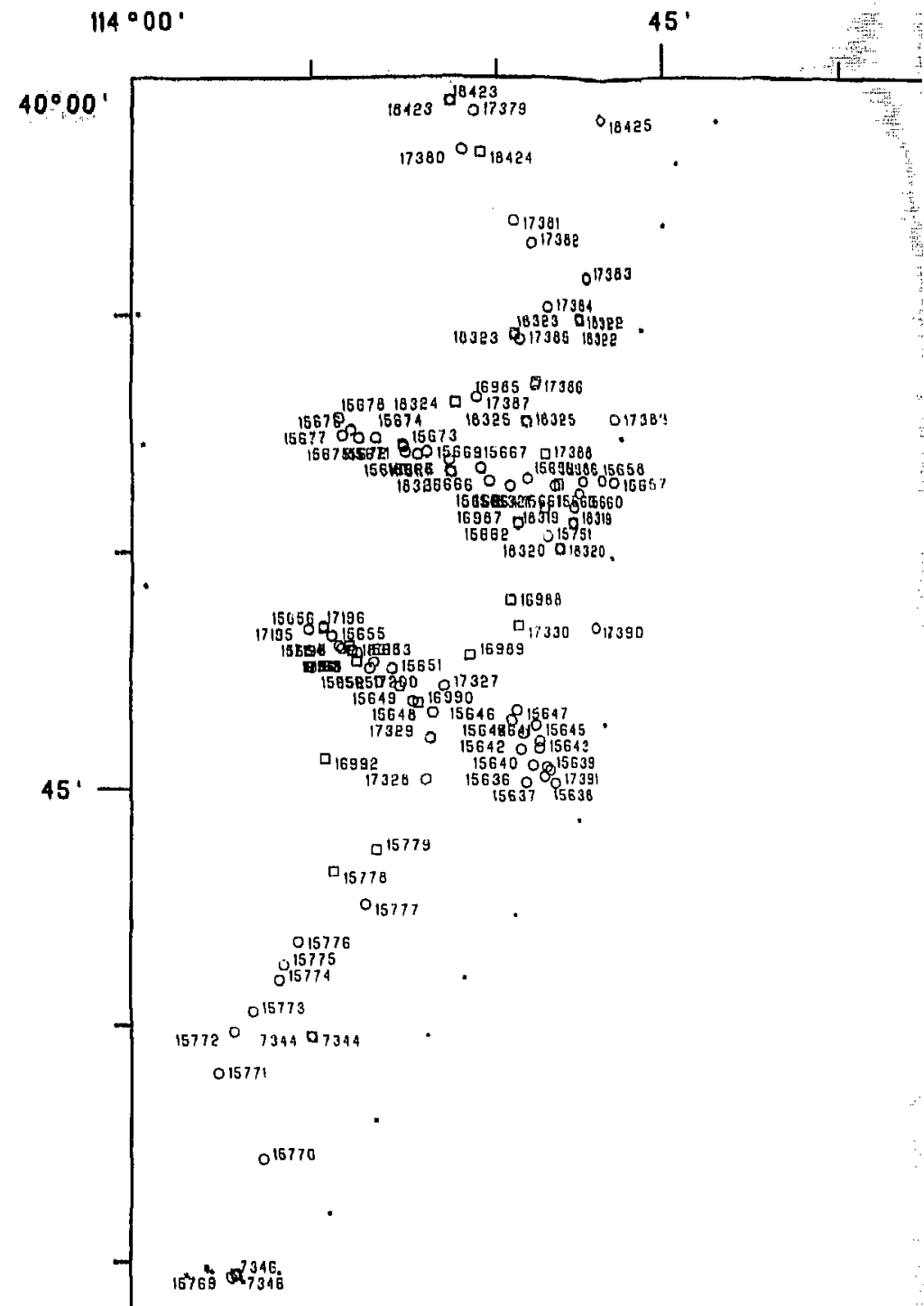




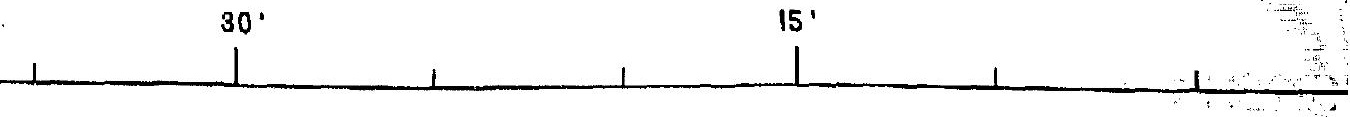


NJ 12-01 $30 \%$ 


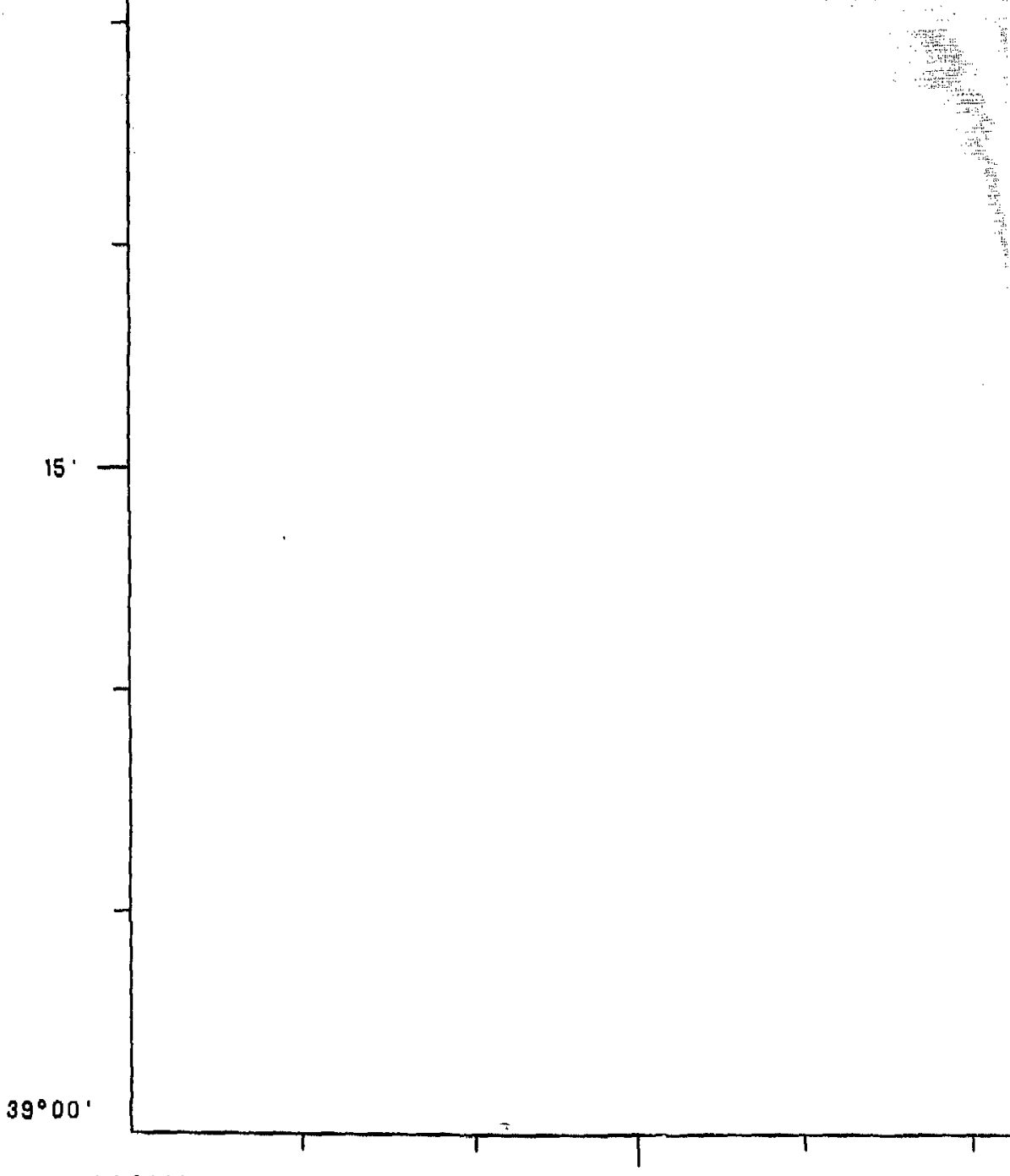

$114^{\circ} 00^{\circ}$

$45^{\prime}$

SYMBOL EXPLANATION

SITE TYPES. SEDIMENT SAMPLES

口 HET

O DRY

$\diamond$ SPRING 


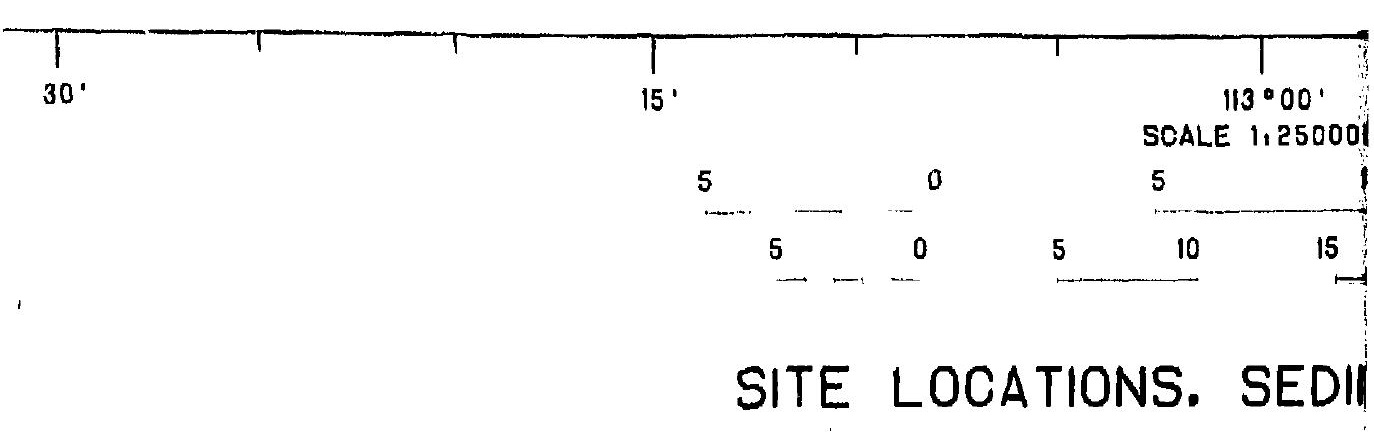




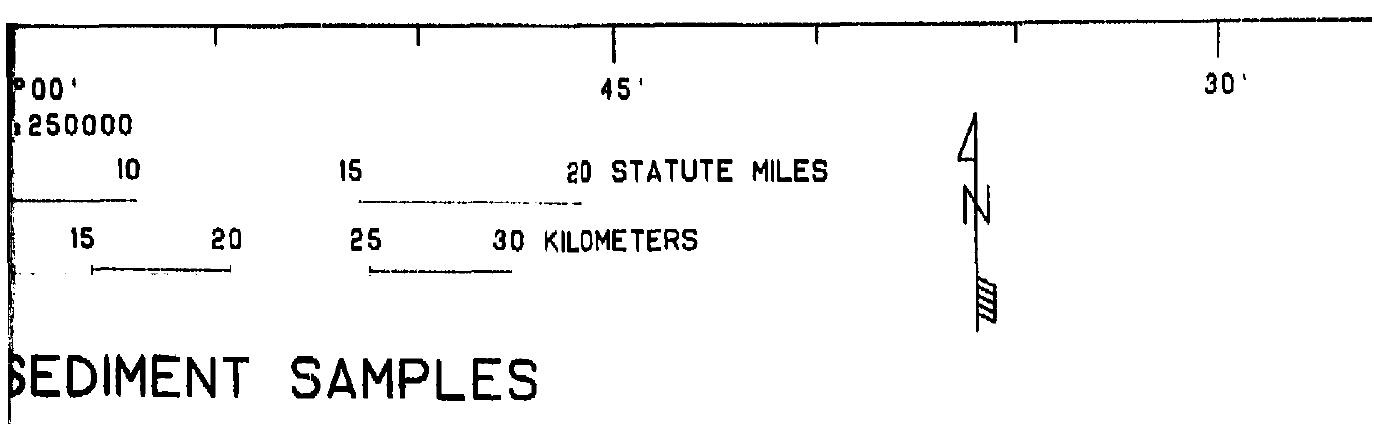



$113^{\circ} 00^{\prime}$

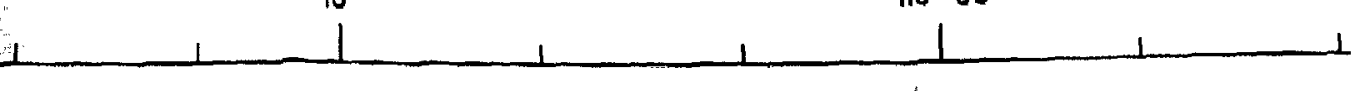


NJ 12-01 
NJ 12-01 


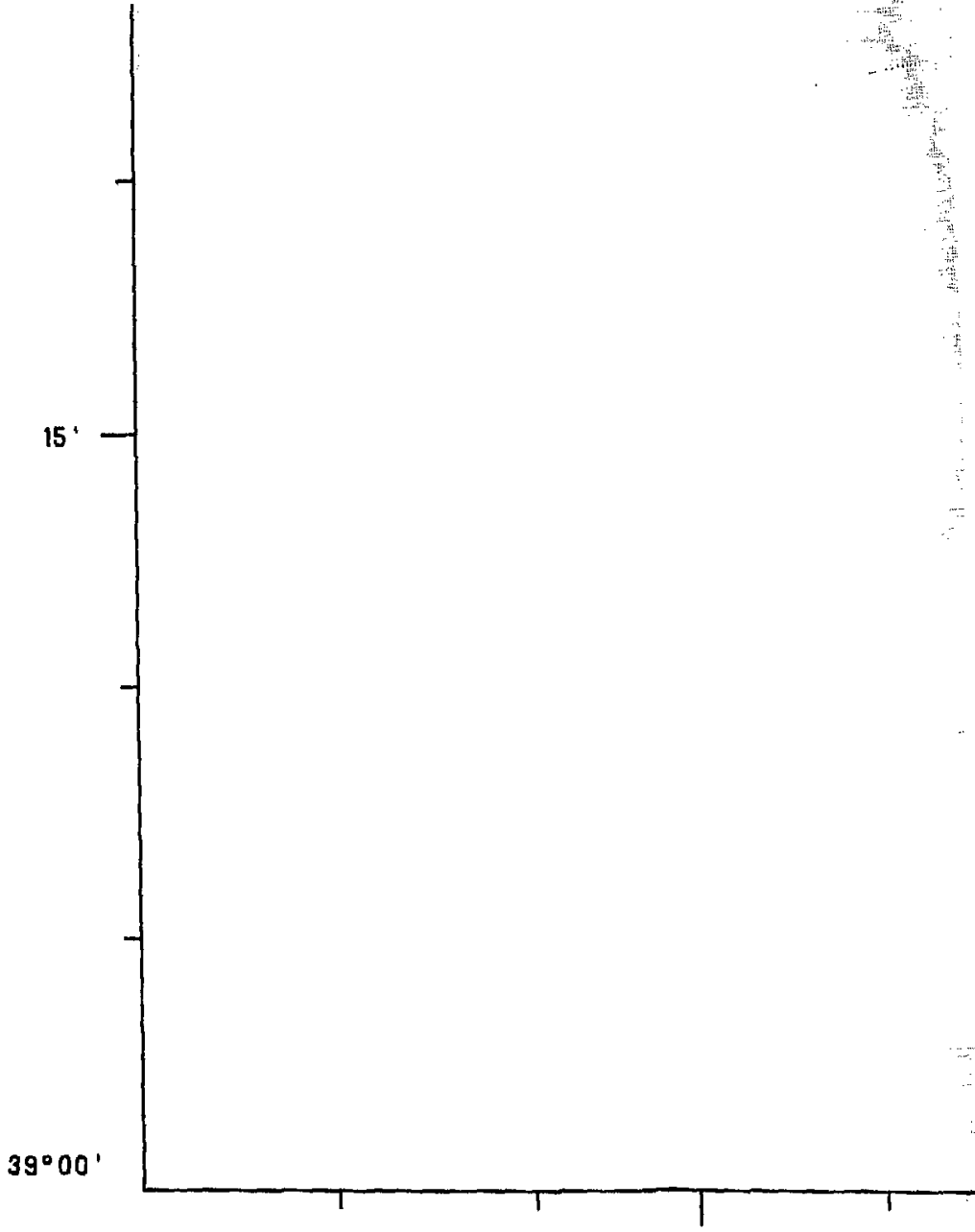

$114^{\circ} 00^{\prime}$

LAWRENCE LIVERMORE LABORATORY

UNIVERSITY OF CALIFORNIA

\section{$45^{\prime}$ \\ SYMBOL EXPLANATION}

\section{SITE TYPES, WATE SAMPLES}

口 RIVER/STREA

$\triangle$ SPRING

$\nabla$ KELL

$\diamond$ LAKE/RESERIIR 


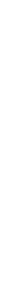

SITE LOCATIONS. WI 


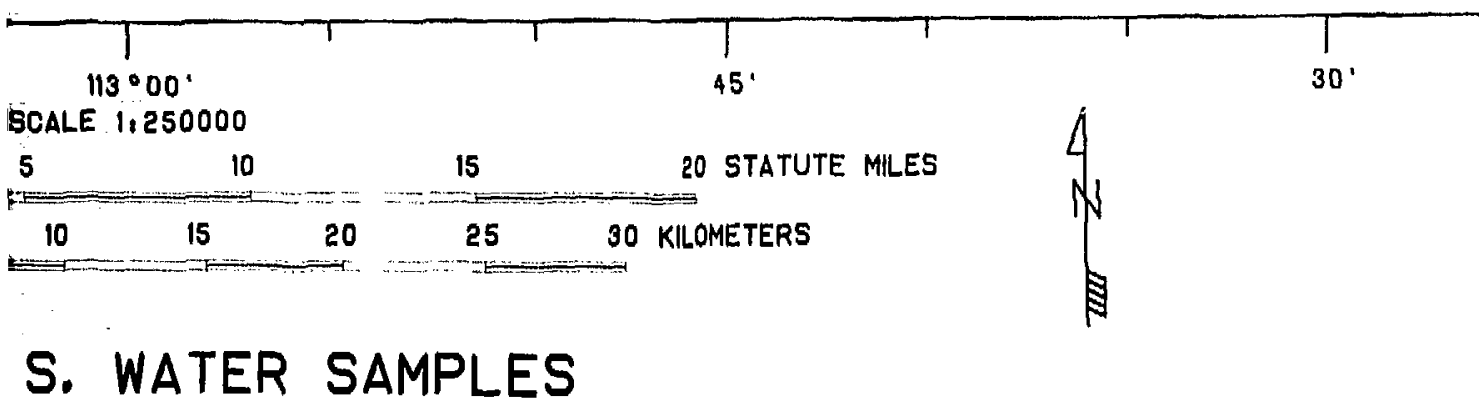




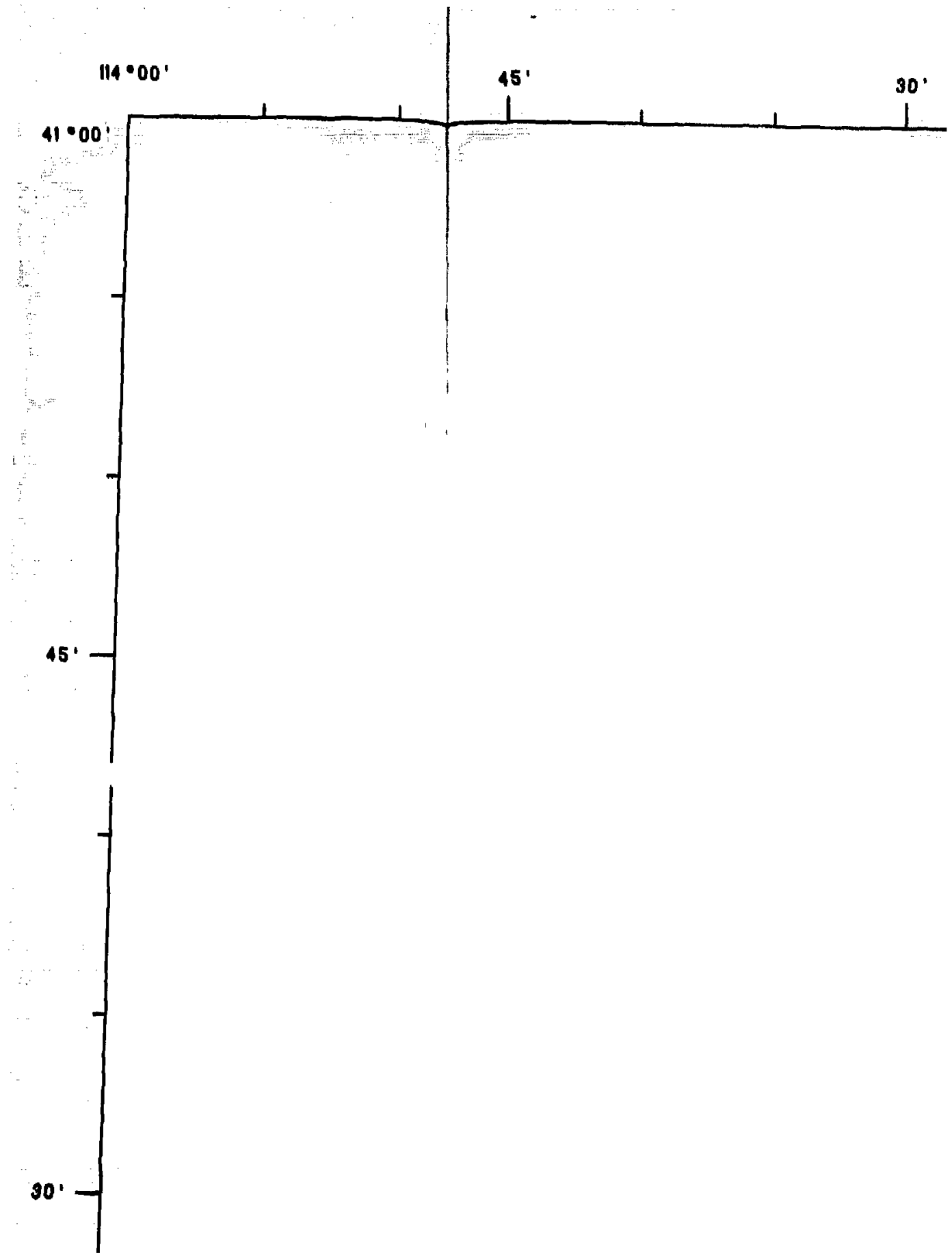



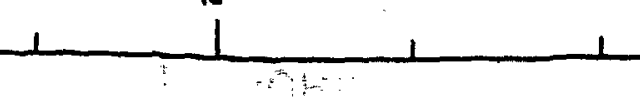
NK $12-10$

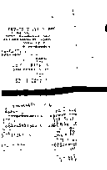

$45^{\circ}$

$$
30^{\prime}
$$

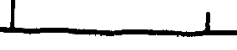

1

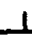


NK $12-10$

$30^{\circ}$

15 '

He 00

1

$41 \circ 00$ ?

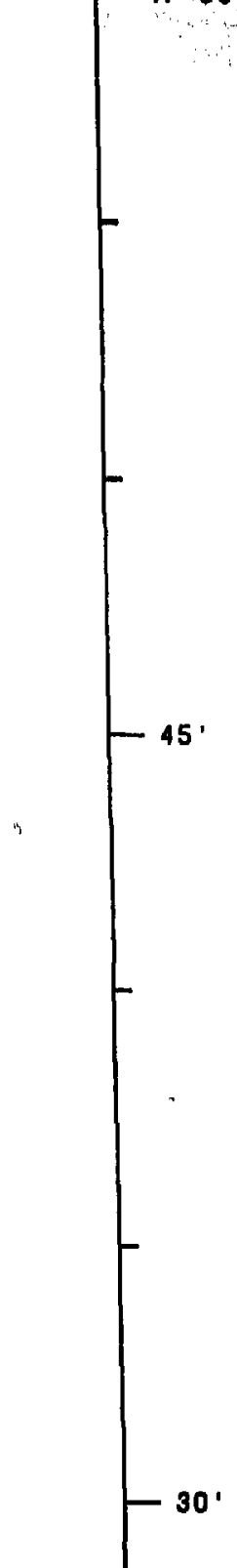




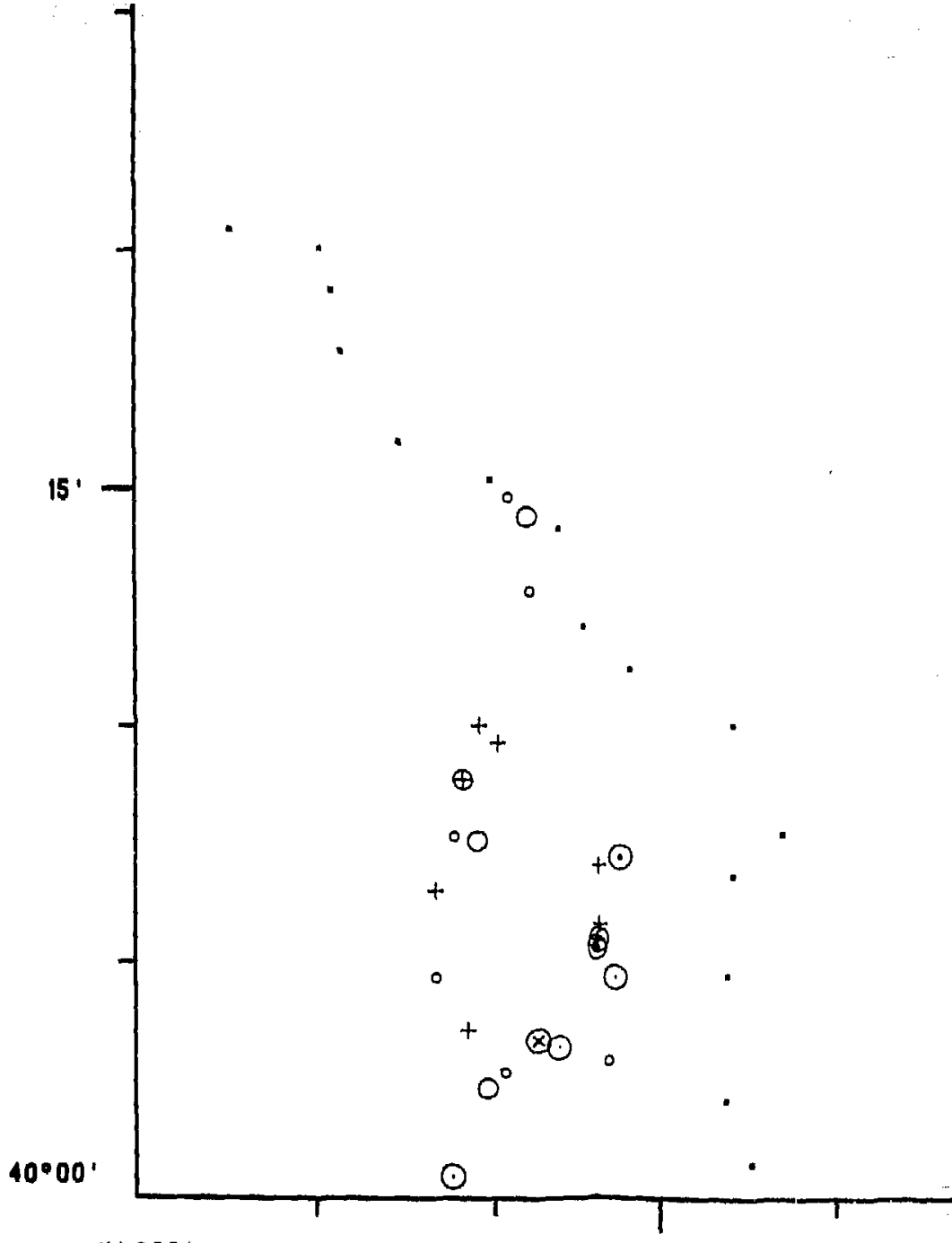

$114^{\circ} 00^{\prime}$

$45^{\prime}$

SYMBOL EXPLANATION

THORIUMC TOTALICONOENTRATIONS

LAWRENCE

LIVERMORE

LABORATORY

UAIVEREITY OF OALIFOANIA

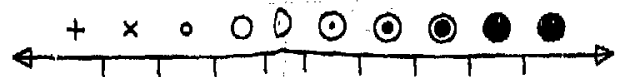

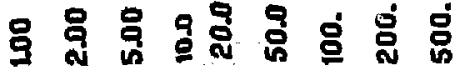

PARTS PER MLION(PPH)BY WEICHT

$+\quad$ LESS THN 100 PPM

(OR NOT DETEOTED)

OREATERTHAN 500, PPM 


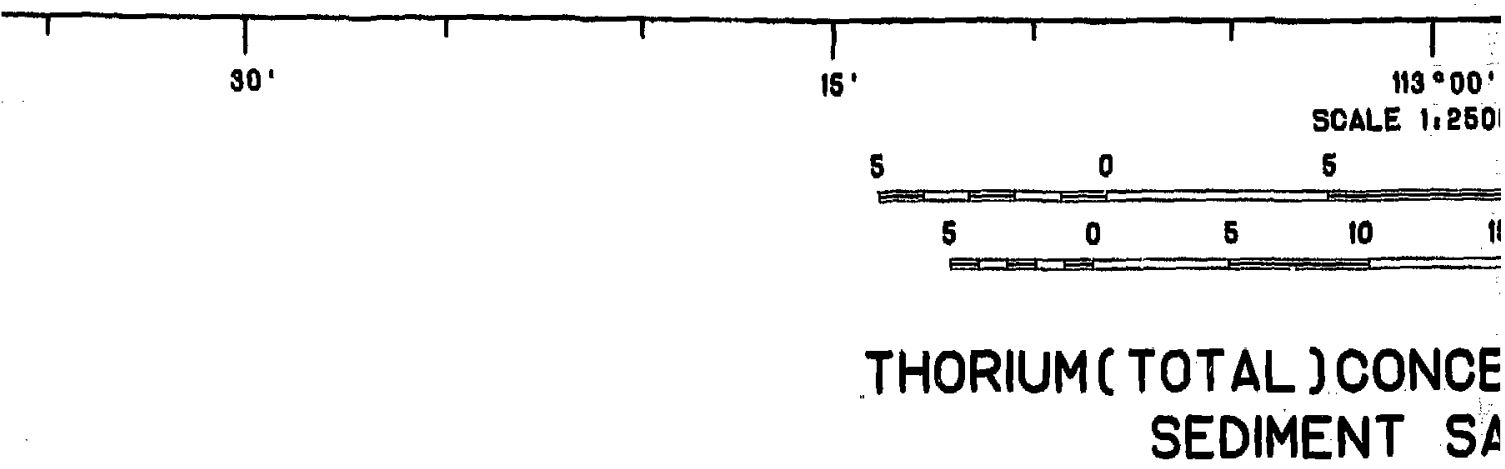




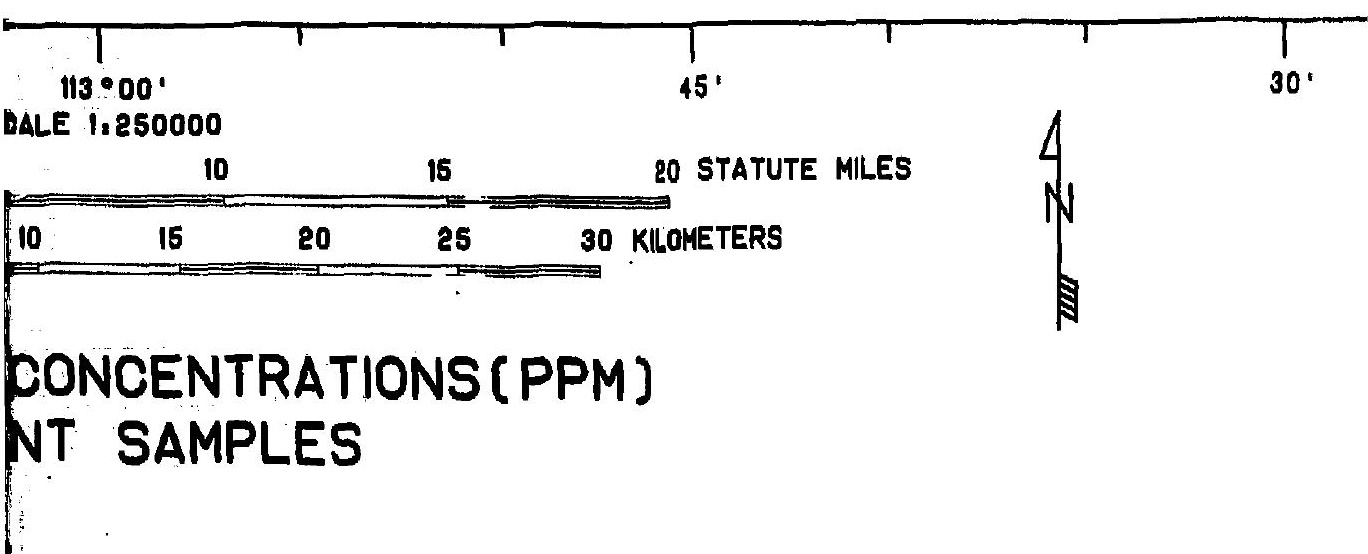




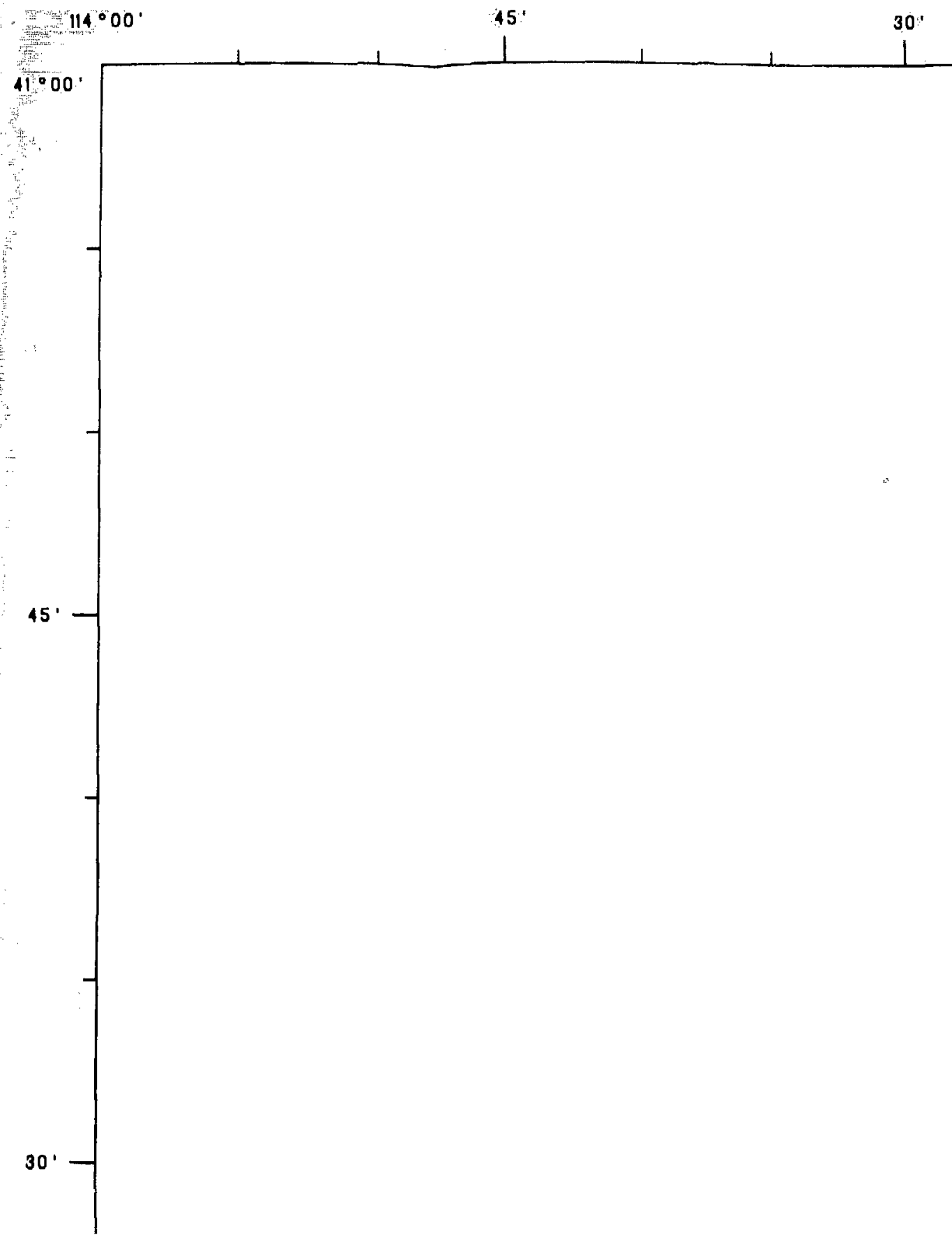


NK $12-10$

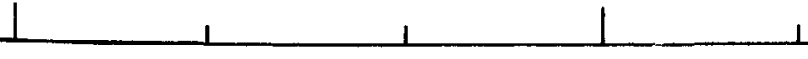


NK $12-10$ 


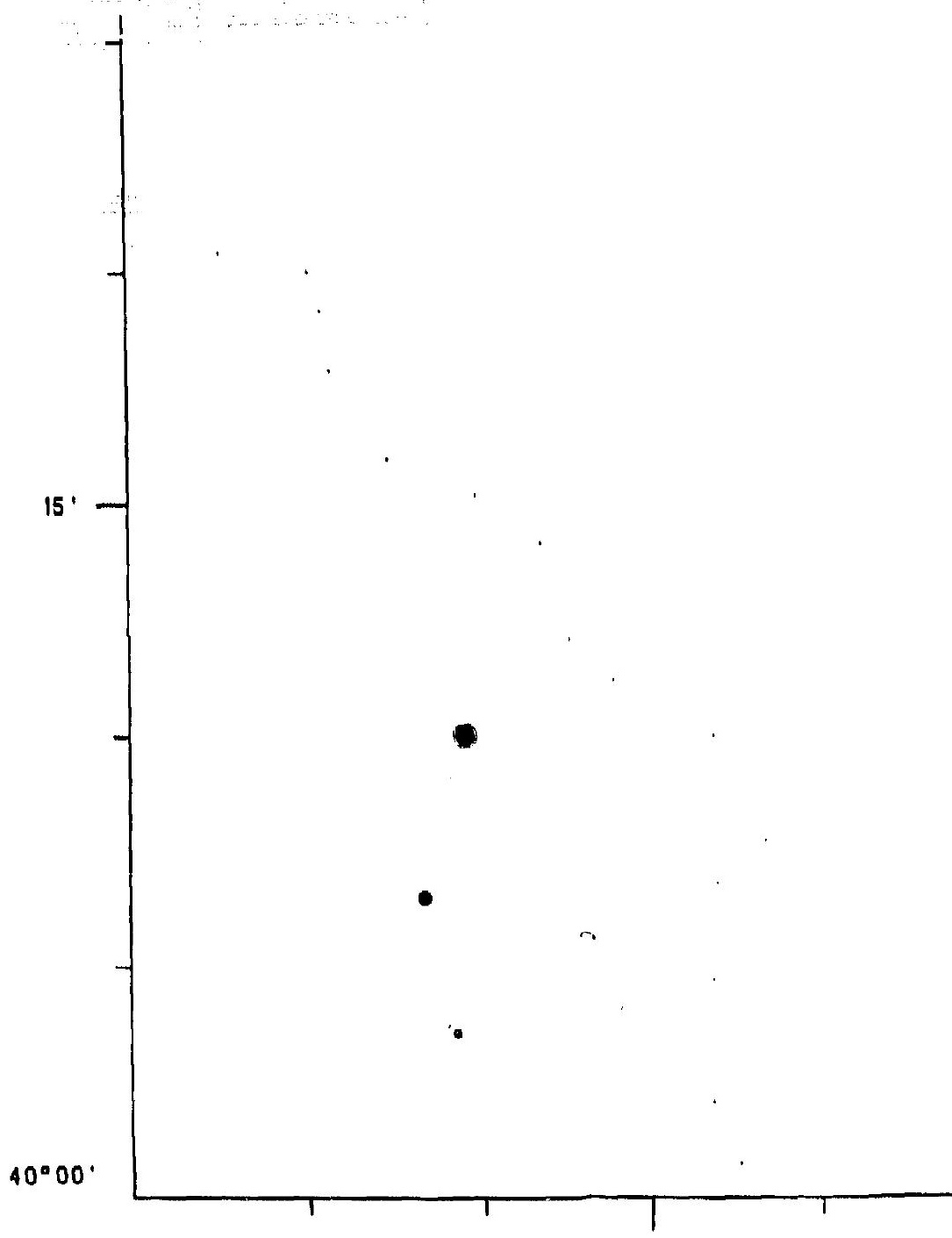

$114^{\circ} 00^{\prime}$

$45^{\prime}$

SYMBOL EXPLANATION CONDUCTIVIYY ( $M M H O / O M$ )

LAWRENCE

LIVERMORE

LABORATORY

UNIVERSITY OF CALIFOANIA

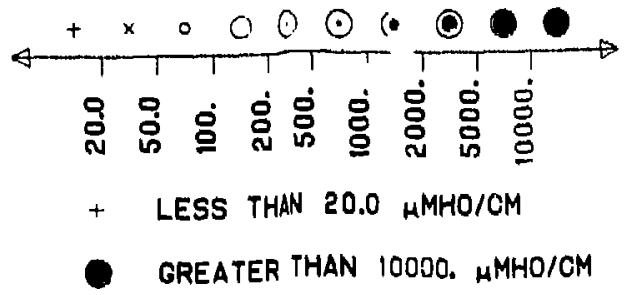




\section{DEEP CREEK RECONNAISSANCE STUDY




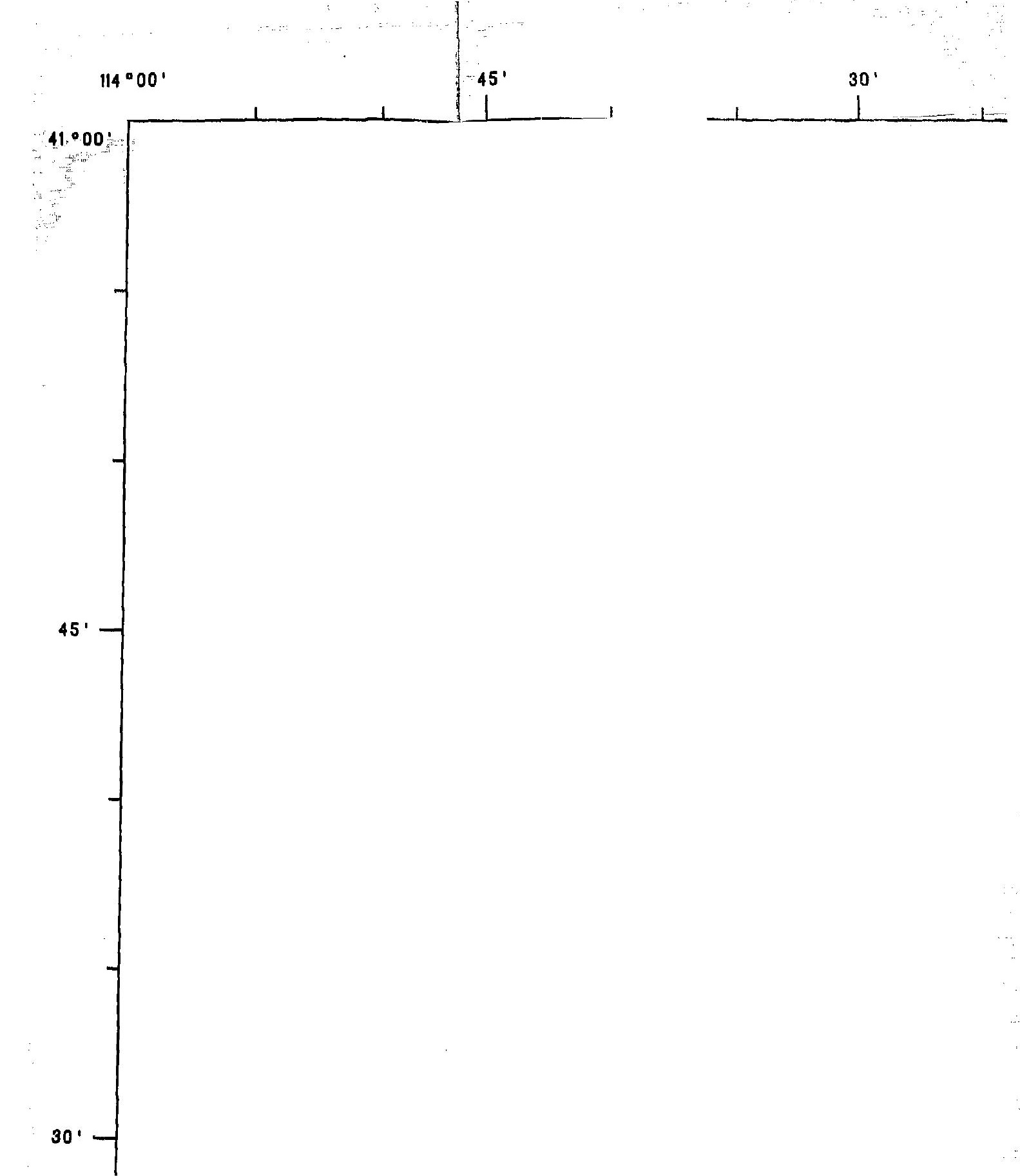


NK $12-10$

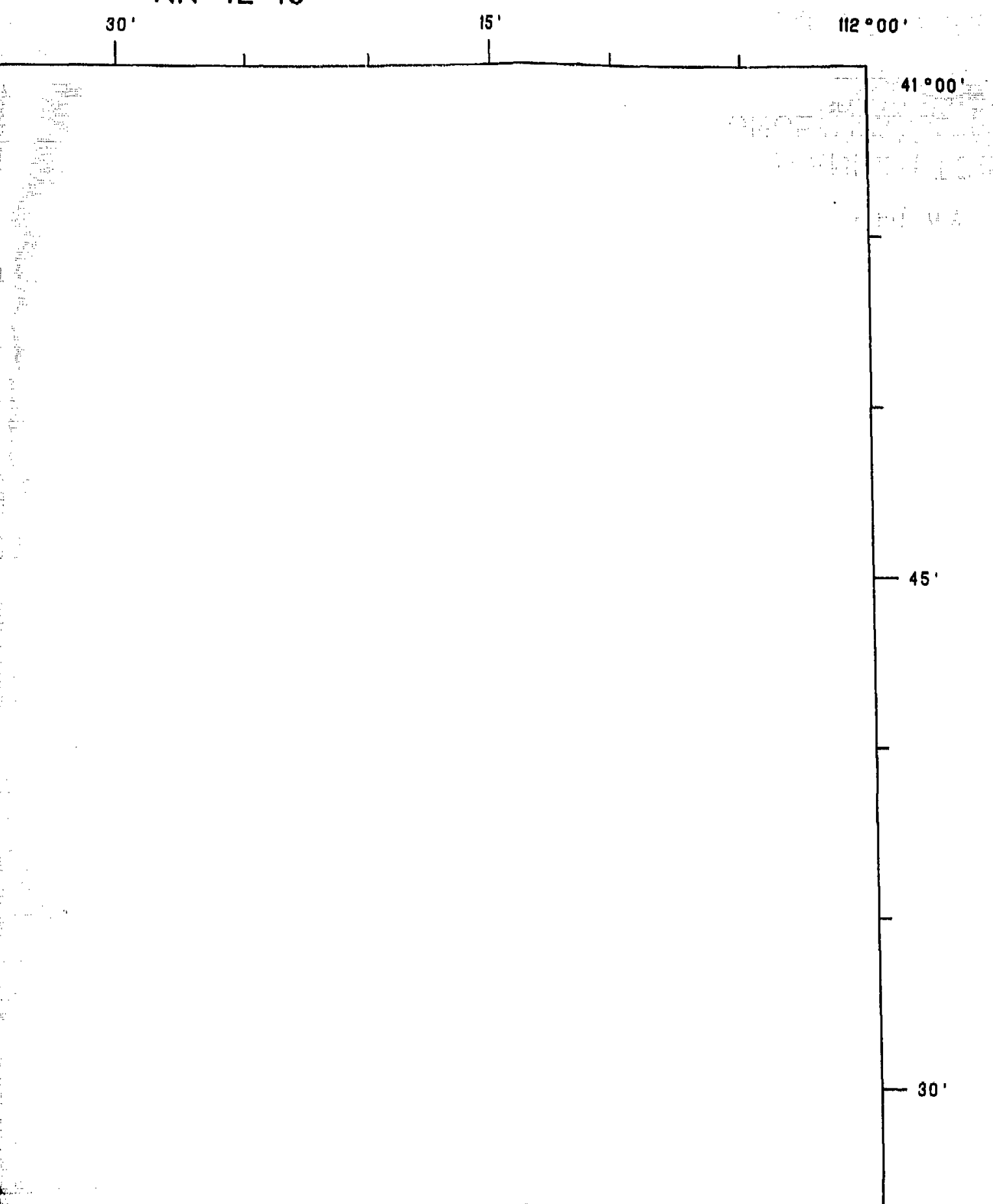




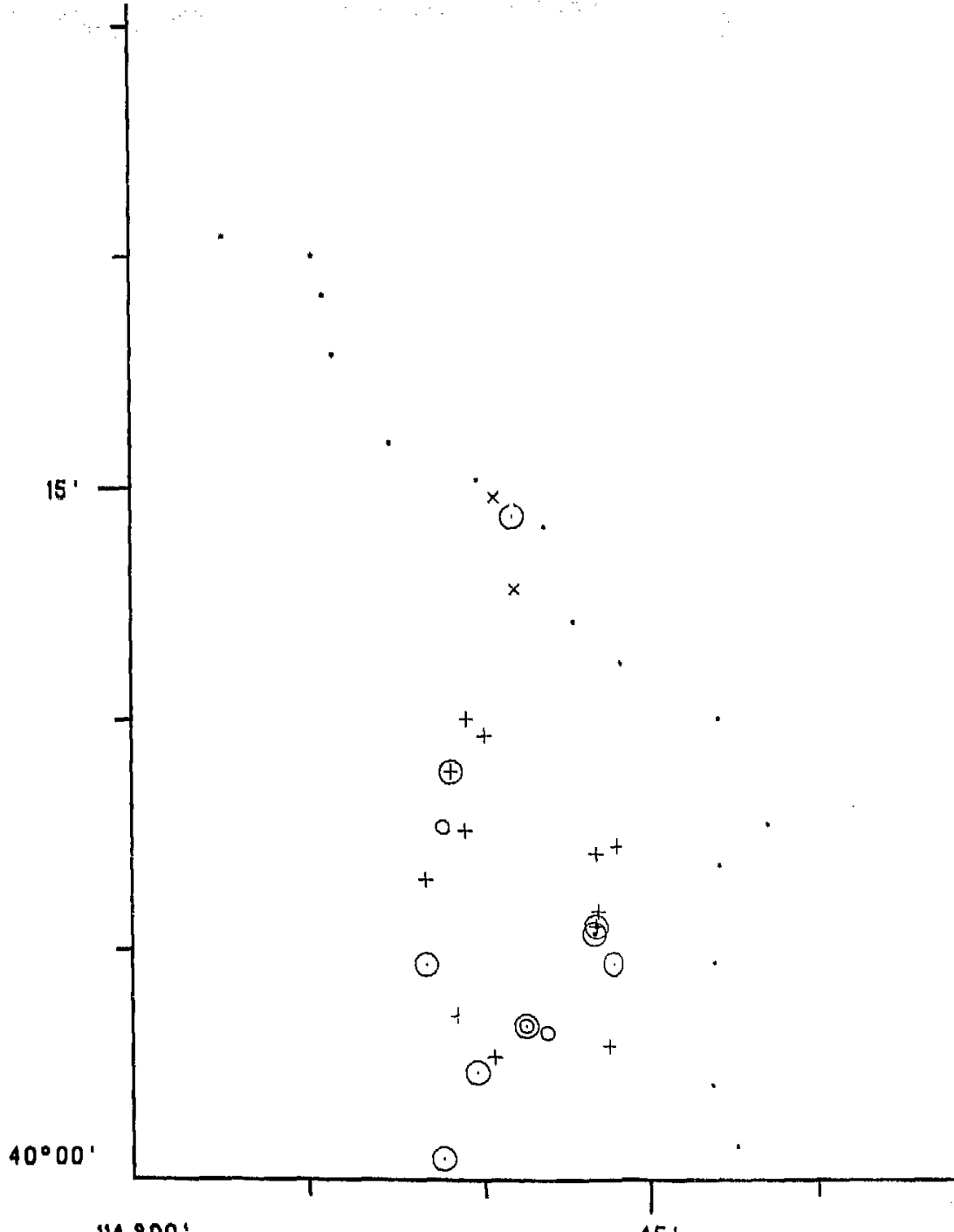

$114^{\circ} 00^{\prime}$

$45^{\prime}$

\section{SYMBOL EXPLANATION}

URANIUMC TOTAL JOONOENTRATIONS

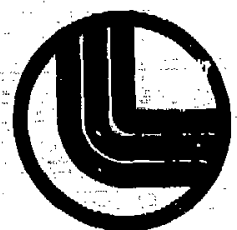

LAWRENCE LIVERMORE

LABORATORY

UNIYERSITY OF OALIFOANHA

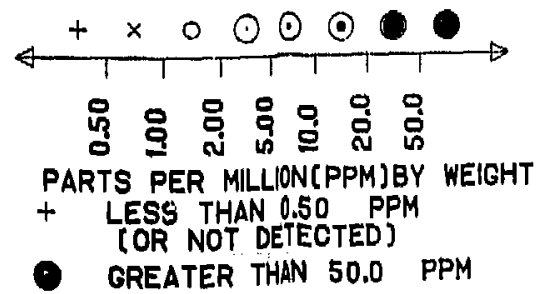

- PROJECT BOUNDARY 


15
$30^{\circ}$




\section{OVERLAY 2B \\ URANIUM(TOTAL) \\ CONCENTRATIONS (PPM) \\ DEEP CREEK \\ RECONNAISSANCE STUDY




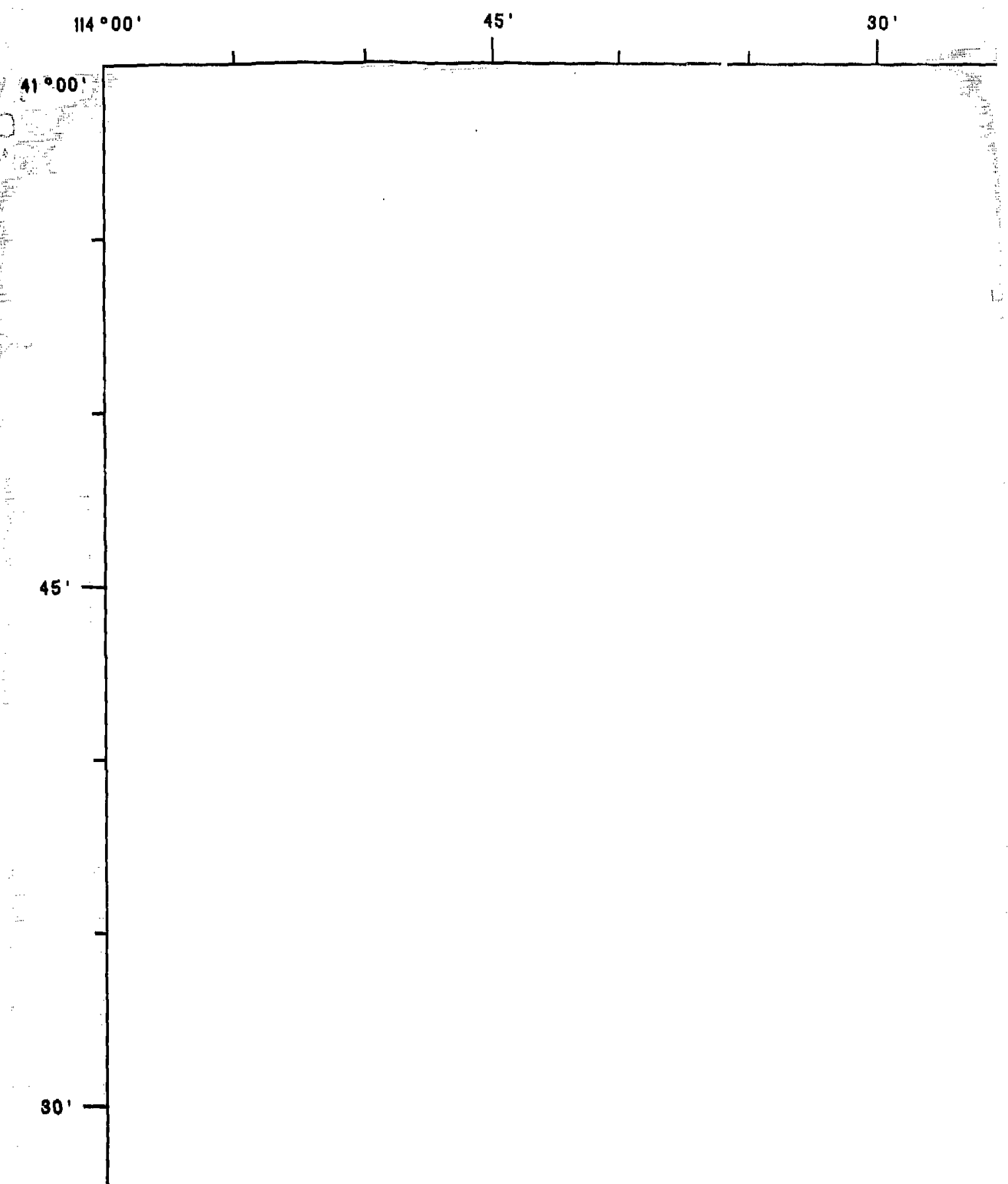


TOOELE 
NK $12-10$

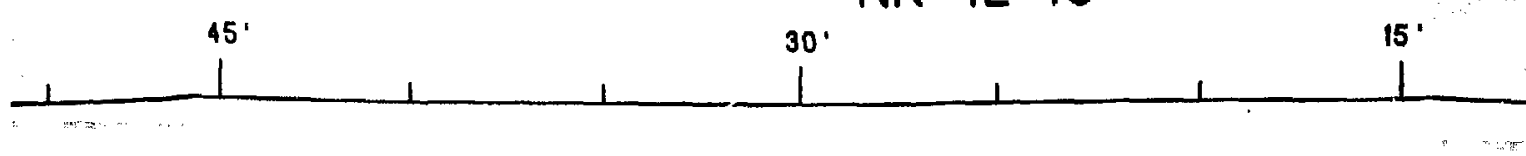


NK $12-10$

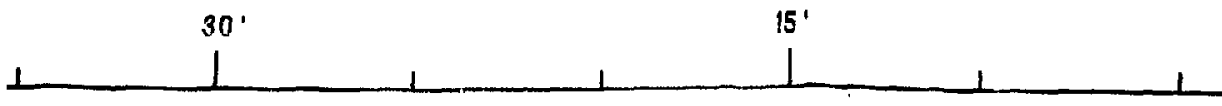




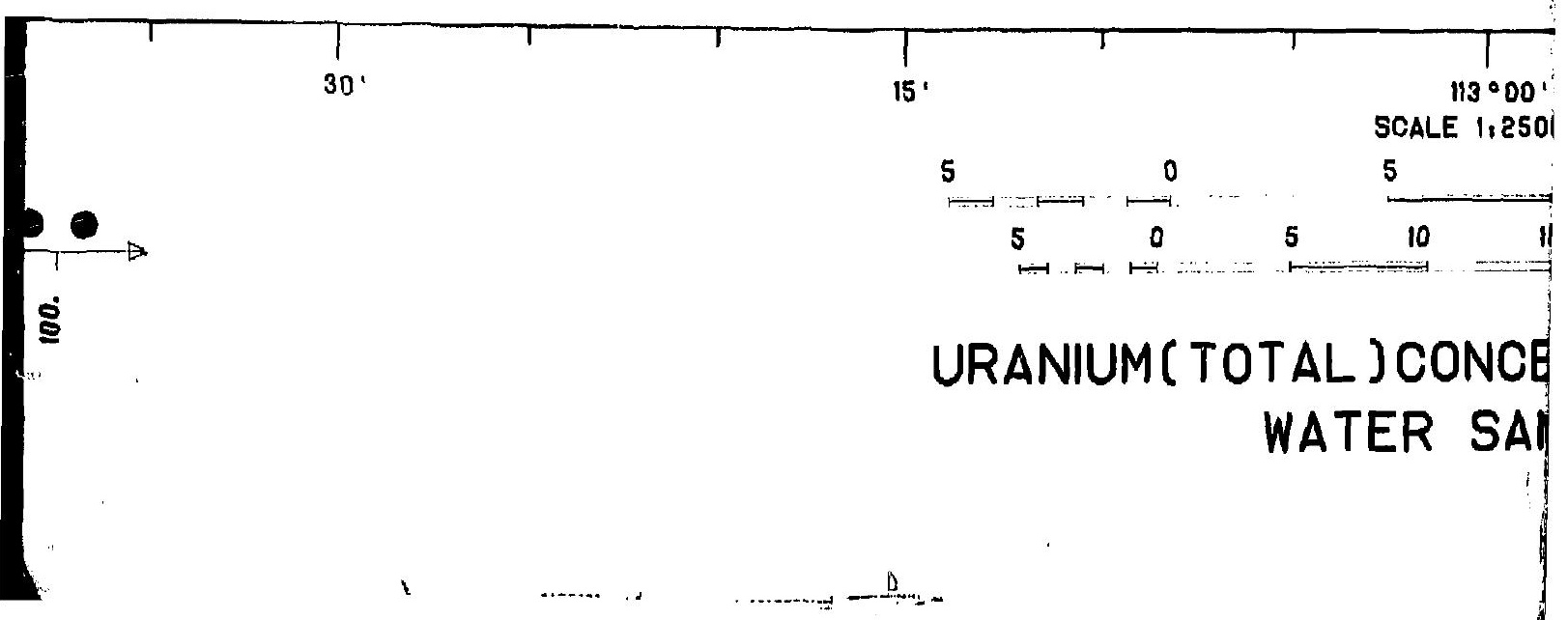


$114^{\circ} 00^{\circ}$

$45^{\circ}$

$41 \cdot 00^{\prime}$

in

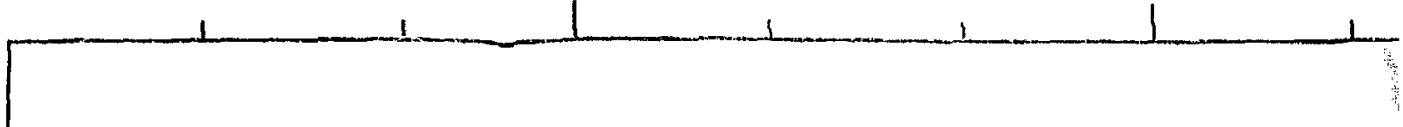

45 .

. 
NK $\quad 12-10$ 
NK $12-10$ 


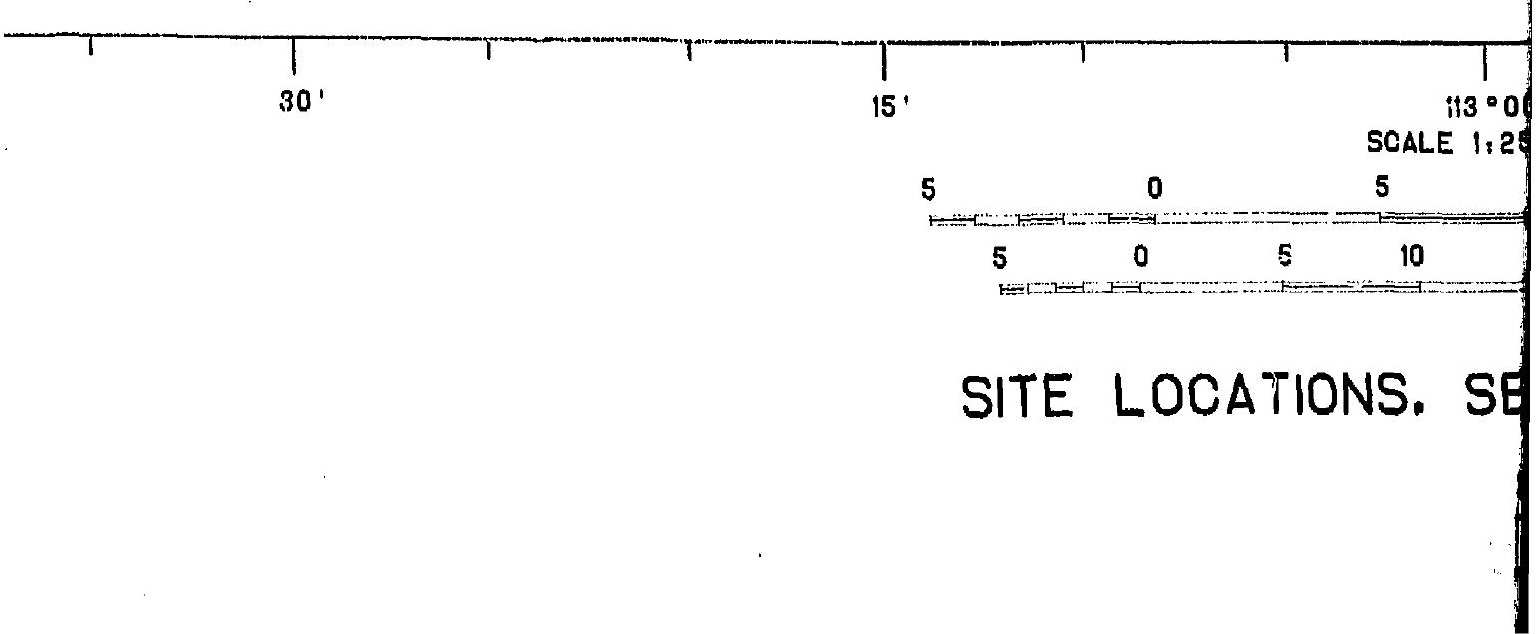




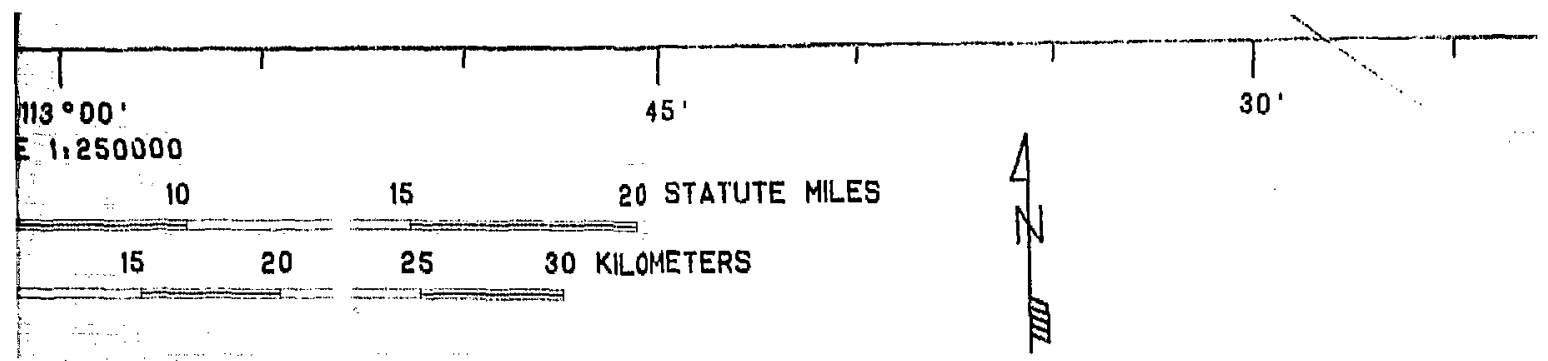

\section{SEDIMENT SAMPLES}




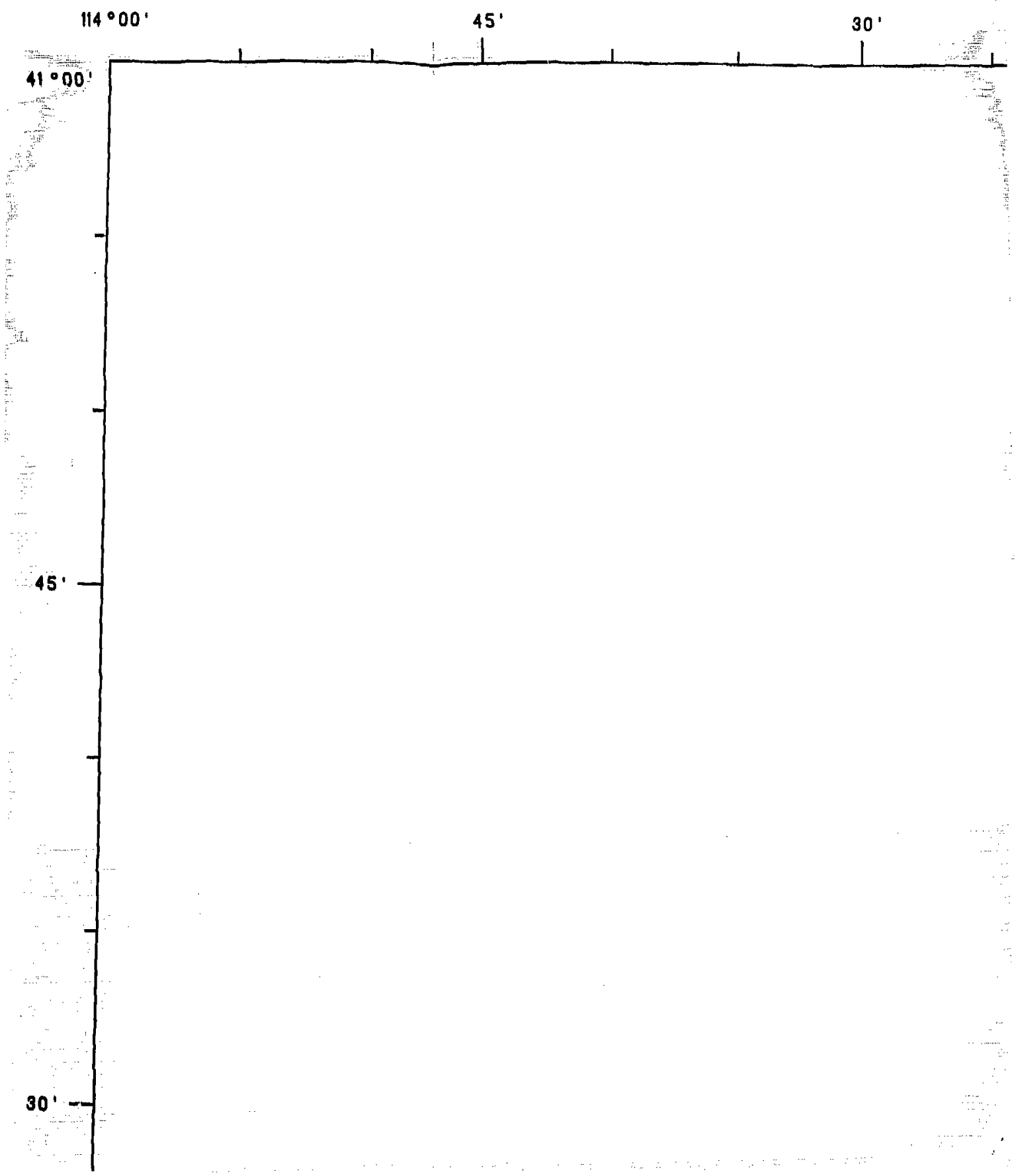


NK $12-10$

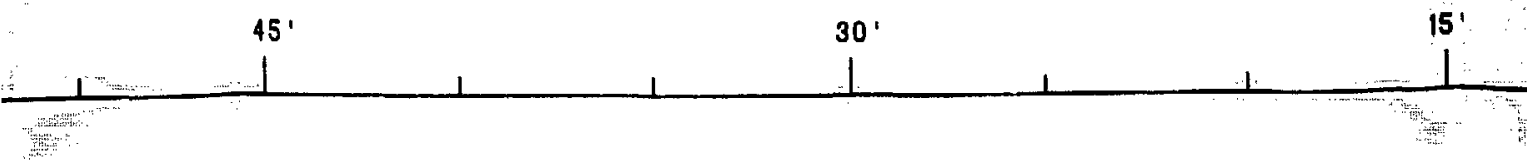


NK $12-10$

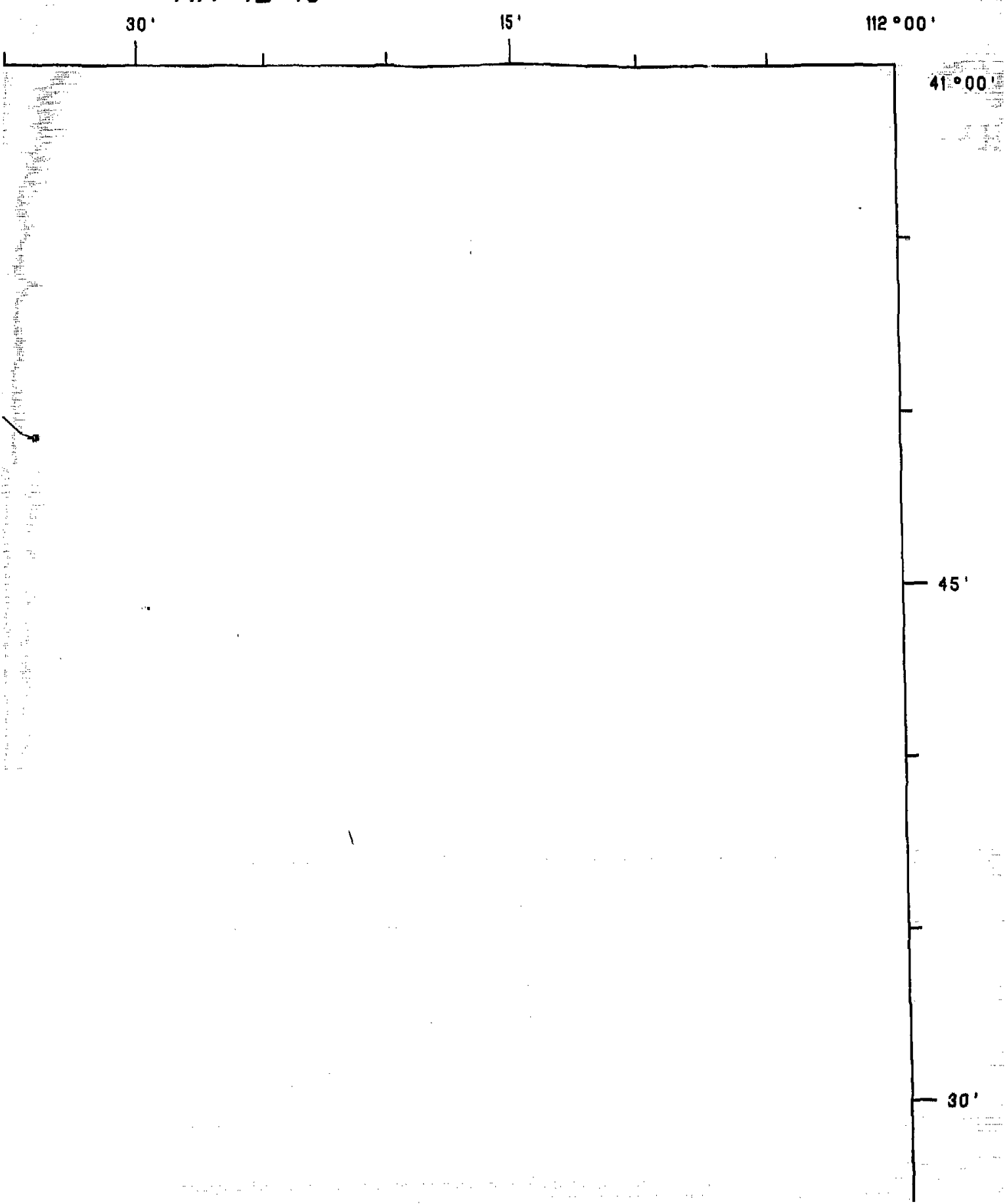




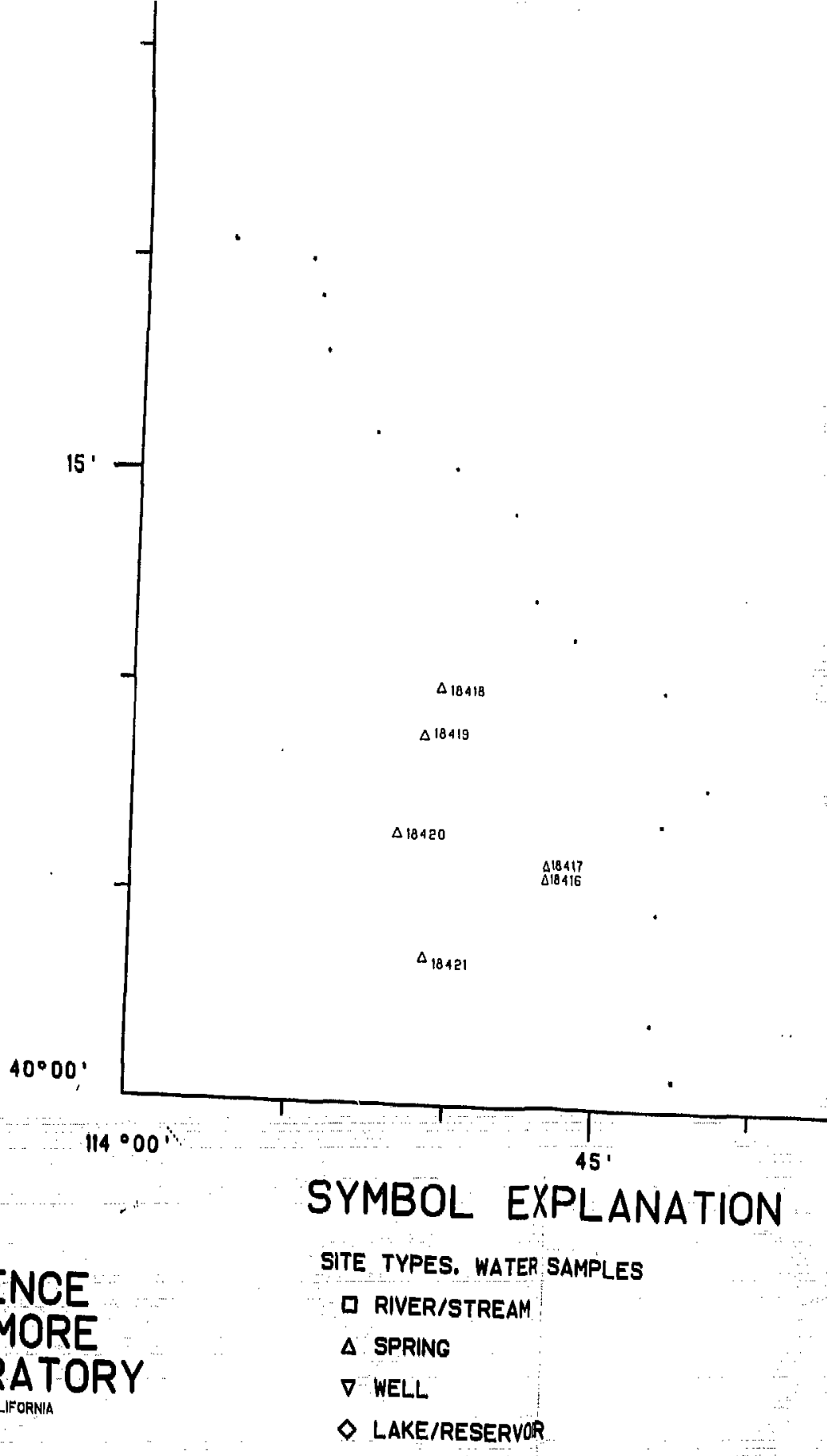




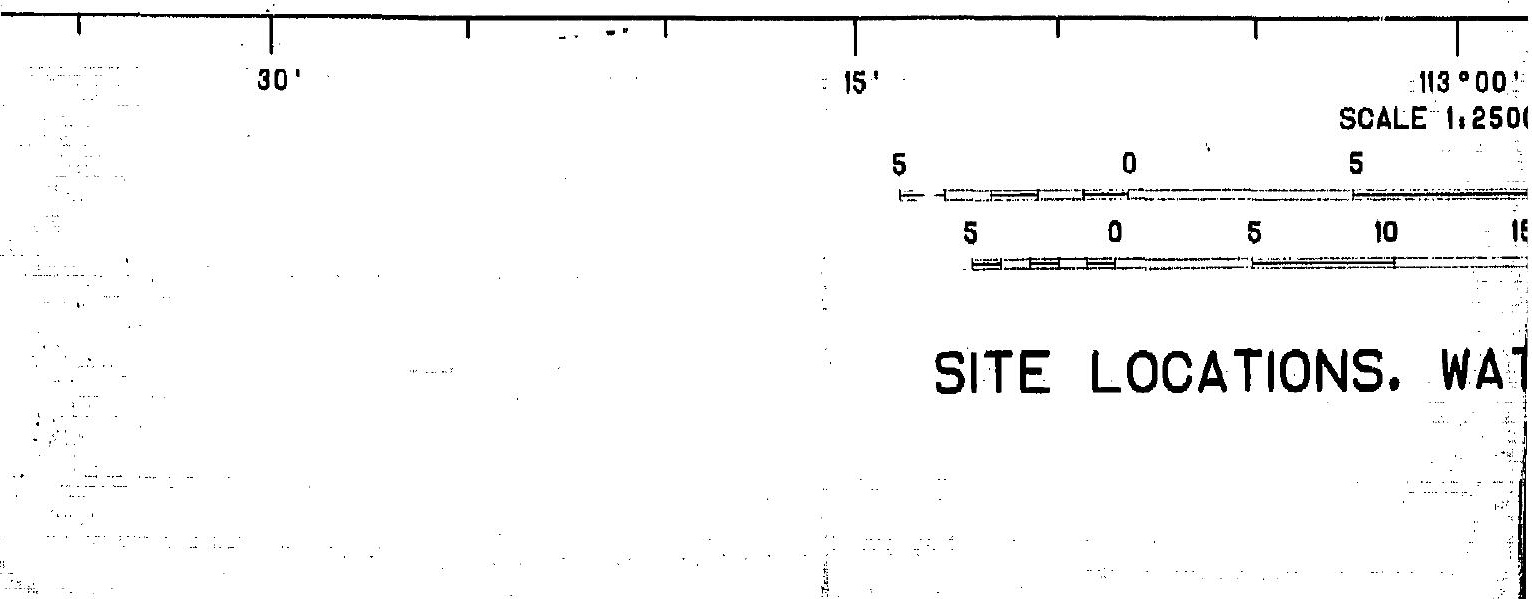


